
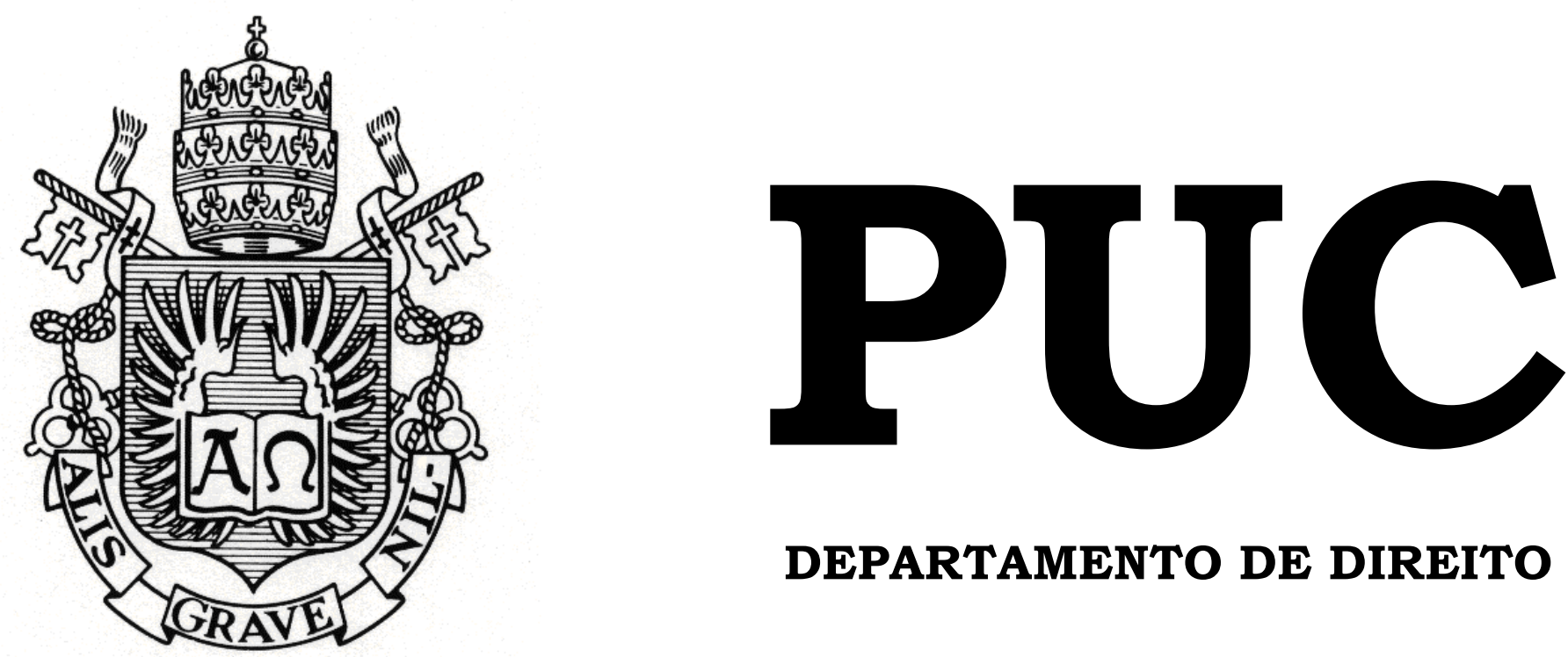

DEPARTAMENTO DE DIREITO

\title{
JUSTIÇA AMBIENTAL E RACISMO AMBIENTAL NO BRASIL
}

por

DANIELA DOS SANTOS ALMEIDA

ORIENTADORA: THULA RAFAELA DE OLIVEIRA PIRES

2016.2

PONTIFÍCIA UNIVERSIDADE CATÓLICA DO RIO DE JANEIRO

RUA MARQUÊS DE SÃO VICENTE, 225 - CEP 22453-900

RIO DE JANEIRO - BRASIL 


\section{JUSTIÇA AMBIENTAL E RACISMO \\ AMBIENTAL NO BRASIL}

por

\section{DANIELA DOS SANTOS ALMEIDA}

Monografia

apresentada

ao

Departamento de Direito da Pontifícia Universidade Católica do Rio de Janeiro (PUC-Rio) para a obtenção do Título de Bacharel em Direito.

Orientadora: Thula Rafaela de Oliveira Pires 


\section{Agradecimentos}

Em primeiro lugar, agradeço a Deus e aos meus pais Vânia e Zeirton, por serem a minha força e me apoiarem incondicionalmente - o seu amor, a sua fé em mim e no meu potencial são o meu combustível para nunca desistir de tentar superar as barreiras que surgem em meu caminho.

Aos professores Thula Pires e Francisco Guimaraens, que contribuíram substancialmente para a minha formação jurídica e me ensinaram que a interpretação do Direito vai muito além da mera leitura de normas positivadas.

Aos amigos queridos que a Pontifícia me presenteou, que tornaram os últimos cinco anos mais divertidos e especiais do que eu poderia imaginar.

E, finalmente, ao Rafael, por ter sido meu porto seguro, presença constante, e quem me ajudou juntar e colar os cacos todas as vezes que me quebrei nesses últimos cinco anos. 


\section{Resumo}

O presente trabalho tem como objetivo promover um diálogo construtivo quanto a análise da problemática ambiental, centrada na gramática da justiça social e utilizando o arcabouço metodológico e epistemológico da Teoria Crítica da Raça. Sob a perspectiva da justiça ambiental, entende-se que não há efetiva e completa repartição igualitária das referidas externalidades, isto é, que esses males não são democraticamente distribuídos e sentidos de forma não individualizada. Ao revés, haveria uma distribuição desproporcional de tais externalidades negativas. Em razão disso, aponta-se a importância de analisar o papel do direito no contexto apresentado e da utilização de referências e parâmetros que permitam a sua interpretação a partir de uma concepção da sociedade brasileira informada pelos seus princípios constitutivos, pensados a partir de sua própria historicidade ao revés da adoção e transposição de parâmetros eurocentrados de análise. Levando em consideração o contexto da gênese e desenvolvimento da unidade celular que formaria a sociedade brasileira, propõe-se a adoção de uma perspectiva que tenha em conta também as relações estabelecidas no plano latino-americano e caribenho e com o continente africano.

Palavras-chave: Direito constitucional. Justiça Ambiental. Racismo Ambiental. Teoria Crítica da Raça. Racismo. Segregação espacial. 


\section{Sumário}

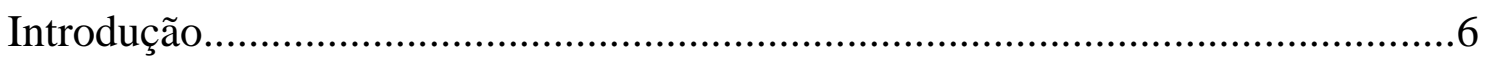

Capítulo 1: Compreendendo o Racismo Ambiental.............................................9

1.1. Teoria aplicada: a Teoria Crítica da Raça como informadora de parâmetros

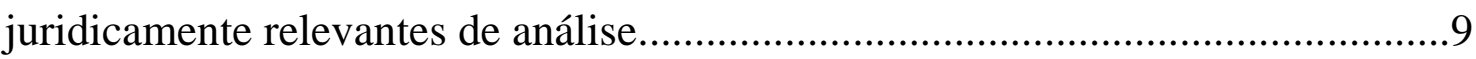

1.2. Racismo Ambiental: apresentação do conceito.............................................20

1.3. Movimento por Justiça Ambiental: da gênese à internacionalização.............27

Capítulo 2: As relações raciais e o racismo no Brasil..............................................38

2.1. O mito da democracia racial brasileira no cenário internacional: o Projeto

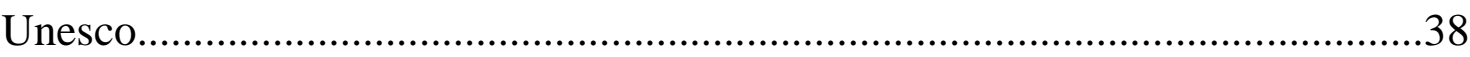

2.2. Racismo ambiental e o racismo no Brasil: análise histórica.............................46

2.3. Segregação espacial socioracial no contexto urbano......................................61

Capítulo 3: O combate ao racismo ambiental no Brasil..........................................73

3.1. A luta por justiça ambiental no Brasil............................................................73

3.2. Por uma perspectiva racialmente centrada...................................................89

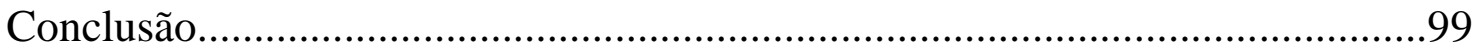

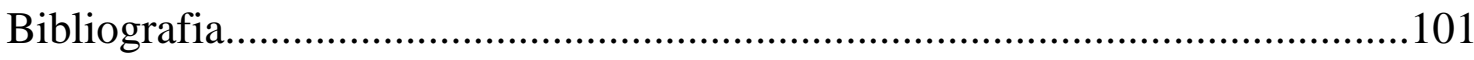




\section{Lista de abreviações}

CLS - Critical Legal Studies

CRFB - Constituição da República Federativa do Brasil

FASE - Federação dos Órgãos para Assistência Social e Educacional

FEEMA - Fundação Estadual de Engenharia do Meio Ambiente

FIOCRUZ - Fundação Oswaldo Cruz

FNB - Frente Negra Brasileira

IBGE - Instituto Brasileiro de Geografia e Estatística

PNUMA - Programa das Nações Unidas para o Meio Ambiente

OMC - Organização Mundial do Comércio

TCR - Teoria Crítica da Raça

TEN - Teatro Experimental Negro

UE - União Europeia

UNDP - United Nations Development Program

UNESCO - Organização das Nações Unidas para a Educação, Ciência e Cultura 


\section{Introdução}

Inicialmente, cumpre elucidar que o presente trabalho não se dedica a atestar a existência ou não de casos de racismo ambiental no Brasil: não se trata aqui de pesquisa empírica que dispute a possibilidade de se fazer tal afirmação. O objetivo do trabalho é, na realidade, promover um diálogo construtivo a respeito da questão com dois interlocutores distintos: o operador do Direito, que pode não estar familiarizado com pautas concernentes à luta por justiça ambiental; e com pesquisadores, ativistas e advogados que atuam em prol da justiça ambiental, da justiça social e que lutam contra o racismo ambiental.

À conta disso, parte-se de noções assentadas no seio do movimento por justiça ambiental, apresentadas oportunamente ao longo do trabalho, sem que se furte de historicamente fundamentá-las. Adota-se a premissa de que o Direito se constitui também à medida que reflete as relações raciais e de que estas, no Brasil, seriam marcadas por profunda desigualdade, sobretudo à luz dos indicadores "raça" e "classe" - que receberam destaque no recorte efetuado no presente trabalho. É que, em razão dessa constatação, pode-se dizer que o Direito incorpora relações de subalternização e desigualdades presentes no corpo social, que seriam consequentemente também incorporadas às instituições, norteando e reafirmando práticas que permitiriam a perpetuação e constante atualização e manutenção dessas relações de desigualdade. Daí exsurge, note-se, a evidente importância de discutir a problemática que aqui se apresenta no âmbito do estudo do direito, considerando que o movimento e papel que o direito exerce nessa dinâmica pode vir a atentar contra princípios por ele consagrados.

Para o primeiro interlocutor, o que se chama à atenção é justamente a necessidade de refletir a respeito do papel que o direito exerce nessa dinâmica e da adoção de parâmetros de estudo do direito que levem em conta a existência de relações de hierarquização social historicamente forjadas na sociedade brasileira. Isto é, há que se notar que o direito, 
porquanto reflete as relações sociais e as premissas que a estas são subjacentes, incorpora diversas das tensões e ruídos nelas existentes, revestindo-as de aparente neutralidade.

Não se pretende, por óbvio, esgotar todas as possíveis lentes de análise que se prestariam a dar conta das falhas aqui apontada. Uma das propostas apresentadas é a utilização de ferramentas já levantadas pela Teoria Crítica da Raça. Neste ponto merece destaque o questionamento da pretensa neutralidade com a qual buscamos revestir as normas, políticas e atos jurídicos. Isto porque, por mais que se pretenda a neutralidade, há, de um lado, o fato de que o próprio direito reflete e incorpora uma série de fissuras presentes na sociedade brasileira, e de outro, o fato de que essas normas tendem a impactar de forma distinta diferentes grupos sociais e raciais, porque, a almejada neutralidade e a mera garantia de igualdade jurídico-formal per se não são sempre aptas a afastar disparidades provenientes do fato de que a implementação da norma não se dá no plano ideal - onde, em tese, presume-se a igualdade material - mas numa realidade profundamente desigual.

À conta dessas considerações é que se defende que se tenha em conta o fato de determinadas formas de discriminação terem alçado nível estrutural - sem que se ignore as dificuldades e complexidades que lidar com esse tipo de discriminação gera. Chama-se atenção para a importância da adoção do fator "raça" como variável relevante de análise, não só do ordenamento jurídico, mas do direito em sua dimensão institucional, histórico-política e estrutural, eis que se entende que isso permite evidenciar alguns aspectos por vezes obscurecidos ou negligenciados.

Com o segundo interlocutor o diálogo estabelecido segue por outros termos, vez que já existem iniciativas de pesquisadores na área que se identificam com algumas das propostas relacionadas à Teoria Crítica da Raça. Muito ainda se disputa, entretanto, quanto a posicionar no epicentro de análise outra variável que não a classe. É que em diversos estudos e artigos a injustiça ambiental é fundamentada no conflito gerado pela 
acumulação de capital, pelo que ficam prejudicadas análises que partam de outros centros de análise, máxime que logrem visibilizar outras formas e graus de discriminação não ofuscados sob o indicador socioeconômico. Apesar de já se reconhecer, de maneira geral, a importância da variável "raça", é a "classe" que recebe notável primazia de análise, categoria sob a qual outros vetores recebem menos visibilidade.

De certo modo, o grau de invisibilização do racismo ambiental se daria porque, no Brasil, o movimento negro, suas iniciativas e agências, ainda não gozariam de plena visibilidade, havendo ainda resistência em se reconhecer os determinantes raciais dos conflitos sociais. Por essa razão, optou-se não só por apontar as premissas teóricas que indicam a existência de racismo ambiental no Brasil e informações que embasam a hipótese, como também algumas das bases estruturais que apontam para a existência de tensões raciais e visibilizam a precedência, em alguns casos, do fator raça ao indicador econômico como uma determinante. 


\section{Capítulo 1: Compreendendo o Racismo Ambiental}

\subsection{Teoria aplicada: a Teoria Crítica da Raça como informadora de parâmetros juridicamente relevantes de análise}

A presente análise parte da concepção de que o Direito, enquanto corpo de regras e princípios que organiza a vida em sociedade, é também reflexo da gama de relações nela existentes. Ademais, a análise ora apresentada parte da premissa de que, no Brasil, as relações sociais são marcadas por profunda desigualdade, especialmente à luz dos indicadores "raça" e "classe". Desta feita, considera-se que, na medida em que reflete traços marcantes do tecido social, o Direito incorpora relações de subalternização e desigualdades nele presentes. Assim, são incorporadas às instituições e ordenações práticas e premissas de atuação que reproduzem ou reafirmam relações dominação. É bem de ver que normatizações formal e aparentemente neutras quando aplicadas a um contexto de desigualdade social são capazes de produzir distorções, acarretando, ao fim e ao cabo, uma tutela desproporcional, não equânime.

Cumpre, portanto, analisar a importância e papel do Direito nessa dinâmica. À conta disso, propõe-se a adição à análise da problemática ambiental $^{1}$ - e da normatização pertinente - de parâmetros racialmente referenciados, que levem em consideração as relações de hierarquização social historicamente forjadas na sociedade brasileira. É que

"colocar o critério raça como informador das reflexões sobre o
direito, não apenas no seu ordenamento normativo, mas
também institucional, histórico, político e estrutural permite
evidenciar aspectos negligenciados e obscurecidos pela
"convergência de interesses' que o modelo de supremacia
branca fomenta" (Silva, 2015, p. 62).

Solórzano et al (2001) indica algumas vertentes genealógicas da Teoria Crítica da Raça, dentre as quais cita as críticas relacionadas ao Critical Legal Studies. Cuida-se de um movimento que emerge na década de 1970 fortalecido e influenciado pela luta pelos direitos civis nos Estados

\footnotetext{
${ }^{1}$ Por "problemática ambiental" refere-se ao conjunto de ônus e externalidades negativas que afligem o meio ambiente em sua amplitude, isto é, não apenas ecologicamente concebido.
} 
Unidos bem como por movimentos feministas. ${ }^{2}$ Embora diversas das críticas iniciais tenham se dirigido ou se ambientado no mundo jurídico, o olhar construído e empenhado a partir da Teoria Crítica da Raça foi incorporado em outros campos de conhecimento, ganhando substancial relevo na área da educação.

$\mathrm{O}$ arcabouço de parâmetros e referências fornecidos pela Teoria Crítica da Raça se presta, neste trabalho, a auxiliar o questionamento de formas de organização e práticas já institucionalizadas. Uma análise norteada pela TCR, frise-se, é permeada pelo questionamento de políticas públicas e leis que, conquanto pretensamente neutras, estejam fadadas a impactar de forma distinta um número de grupos diversificados e que se relacionam numa sociedade marcada pela desigualdade entre tais grupos. $\mathrm{O}$ que se propõe diante do problema apresentado ao longo do trabalho é que se debruce sobre o momento anterior: isto é, antes mesmo de se dedicar à análise do produto (leis, políticas públicas, práticas estatais e de agentes privados, etc.) que resulta na produção de injustiças ambientais e do racismo ambiental, há que se compreender as estruturas que atribuem e delineiam as características daquele produto. Desse modo, torna-se possível estuda-lo com clareza, criticá-lo e formular interferências que alterem suas características, no intuito de progressivamente aniquilar a discriminação institucional.

Nas palavras de Matsuda (1991), a Teoria Crítica da Raça seria

\footnotetext{
"the work of progressive legal scholars of color who are attempting to develop a jurisprudence that accounts for the role of racism in American law and that work toward the elimination of racism as part of a larger goal of eliminating all forms of subordination" (Matsuda, 1991, p. 1331) ${ }^{3}$
}

\footnotetext{
${ }^{2}$ A genealogia traçada por Solórzano et al (2001) inclui também como influenciadores da Teoria Crítica da Raça os Ethnic Studies, Cultural Nationalism, US/Third World Feminism, Marxist/NeoMarxist e Internal Colonial. Os autores indicam, ainda, que a Teoria Crítica da Raça viria se expandindo para incorporar ramos como: LatCrit, FemCrit, AsianCrit, WhiteCrit e TribalCrit (Solórzano et al, 2001, p. 93-94)

${ }^{3} \mathrm{O}$ que se traduz livremente para: "o trabalho de estudiosos progressistas do direito que objetivariam desenvolver uma jurisprudência que leva em consideração o papel do racismo no direito americano e que trabalha pela eliminação do racismo como parte de um objetivo maior de eliminação de todas as formas de subordinação".
} 
A relação entre a Teoria Crítica da Raça e o Critical Legal Studies é perceptível através das críticas traçadas por Lawrence III à doutrina do propósito discriminatório, veiculada pela Suprema Corte dos Estados Unidos no caso Washington v. Davis (Lawrence III, 1987). Em síntese, nos termos da doutrina do propósito discriminatório, para que determinado ato seja tido como racialmente discriminatório a sua motivação deve ser racial, há que se demonstrar a intenção ou propósito de discriminar. Isto, mesmo quando o ato em exame for emanado de autoridade responsável por legislar, aplicar a lei ou de administração.

Os argumentos mais aceitos que dão substrato à referida doutrina se baseiam no que fora assentado pela Corte no caso Davis: a) um padrão que sujeitasse todas as ações governamentais referentes ao impacto desproporcional racial ao escrutínio estrito judicial custaria caro demais; b) um modelo de impacto desproporcional faria com que pessoas inocentes arcassem com os custos da reparação de um dano com cuja causa não contribuíram; c) o teste de impacto seria inconsistente com os valores de proteção igual, pois o tomador de decisão judicial teria que considerar explicitamente a raça; e d) seria inadequado para o sistema judicial escolher remediar o impacto racial desproporcional das ações governamentais neutras em detrimento de outros interesses sociais legítimos (ibid., p. 320$321){ }^{4}$

Há que se notar que a Suprema Corte partiu da premissa de que somente atos intencionalmente discriminatórios infringiriam a igualdade constitucionalmente consagrada, ignorando quaisquer demais formas de atitude discriminatória. O que a Suprema Corte entende existir é uma falsa

\footnotetext{
${ }^{4}$ Traduziu-se livremente do inglês: "(1) A standard that would subject all governmental action with a racially disproportionate impact to strict judicial scrutiny would cost too much; such a standard, the Court argues, would substantially limit legitimate legislative decision making and would endanger the validity of a "whole range of [existing] tax, welfare, public service, regulatory and licensing statutes"; (2) a disproportionate impact standard would make innocent people bear the costs of remedying a harm in which they played no part;' (3) an impact test would be inconsistent with equal protection values, because the judicial decision maker would have to explicitly consider race; and (4) it would be inappropriate for the judiciary to choose to remedy the racially disproportionate impact of otherwise neutral governmental actions at the expense of other legitimate social interests" (Lawrence III, 1987, p. 320-321).
} 
dicotomia - em atos neutros em tese - que se apresenta no binômio: ações intencionais e inconstitucionais e ações não intencionais e constitucionais.

No entanto, o que se entende tradicionalmente configurar "intenção" ou "dolo" não leva em consideração o fato de que decisões relativas a questões raciais são especialmente influenciadas por elementos não intencionais. Diante disso, chama-se atenção para o fato de que ações e comportamentos que produzem resultados racialmente discriminatórios são, em grande medida, influenciados por uma série de elementos incorporados ao inconsciente. Assim é que não é possível que seja - em absolutamente todos os casos - cabalmente detectada a intenção do sujeito em produzir determinado resultado racialmente injusto. Com efeito, numa sociedade em que o racismo se encontra profundamente enraizado, noções racistas podem se difundir e reforçar a partir de mecanismos tácitos ou não expressos.

À luz da Teoria Crítica da Raça, parte-se da premissa de que é necessário incorporar ao estudo do direito o que se sabe a respeito do inconsciente e das bases da discriminação racial - consideradas as particularidades locais e as circunstâncias de identificação supranacionais. Lawrence III (1987) defende que, sendo o propósito do direito a erradicação da discriminação racial, é forçoso reconhecer que o racismo é tanto "normal" - no sentido de frequente, recorrente - quando "irracional" - no sentido de que nem sempre inteiramente conscientemente intencional.

Como explica Silva, “A principal premissa da Teoria Crítica da Raça é a ideia de que
o racismo não é um comportamento considerado anormal, mas
uma experiência diária na sociedade estadunidense. Algo que
reflete igualmente a realidade brasileira. Trata-se de um
comportamento tão culturalmente enraizado, que as práticas
discriminatórias sutis do dia a dia não são percebidas." (Silva,
2015, p. 65)

Isso aponta para a necessidade de se averiguar as bases da sociedade brasileira, sobretudo no campo das relações raciais, bem como denota que a questão da discriminação racial transcende - em muito - o nível individual. Em virtude disso, fazem-se necessárias análises que não só vislumbrem o

\footnotetext{
${ }^{5}$ Não se adentra aqui aos contornos que o termo recebe tecnicamente pelo Direito Penal.
} 
caso a caso de situações pontuais de racismo individual como se dediquem a investigar as premissas das formas socialmente incorporadas e institucionalizadas de racismo, como ponto de partida do combate às formas de desigualdade racial, dentre as quais se inclui o racismo ambiental.

Apesar da origem norte-americana, é possível perceber que, postas em relevo as peculiaridades brasileiras, a Teoria Crítica da Raça se mostra como um instrumento útil enquanto perspectiva epistemológica e metodológica a auxiliar o estudo do caso brasileiro. Ainda, utiliza-se o que se designa como "metodologia colorida", isto é, atenta-se à possibilidade de levantamentos técnicos e científicos assim como a produção de determinados dados serem influenciados por uma perspectiva racial discriminatória, conquanto protegidos por aparente neutralidade, bem como privilegia-se lentes de análise que ponham em relevo maneiras de formação do conhecimento usualmente ignoradas, como contra-narrativas, relatos de experiência em primeira pessoa, etc. É importante visibilizar o papel desempenhado pela academia e pelo direito em relação às formas de discriminação racial existentes.

Scheurich e Young (1997) apontam que as epistemologias ${ }^{7}$ - frisese: não só a sua utilização ou aplicação, mas a epistemologia propriamente dita - correntemente utilizadas teriam viés racialmente discriminatório, pelo que originariam uma nova categoria de discriminação: o racismo epistemológico. A elucidação do conceito demanda que se exponha antes algumas categorias de discriminação racial, em nível individual e estrutural. Em nível individual destacam-se os casos de racismo ostensivo e os de racismo dissimulado, enquanto em escala estrutural se mostra pertinente apresentar a forma institucional e civilizacional de discriminação racial desta última exsurge o racismo epistemológico. ${ }^{8}$

\footnotetext{
${ }^{6}$ A respeito desse referencial metodológico, ver Scheurich e Young (1997).

7 No que os autores assim exemplificam: positivismo, pós-positivismos, neorrealismos, construtivismos, pós-modernismos, dentre outros (Scheurich \& Young, 1997, p. 12).

${ }^{8}$ Os autores trabalham os seguintes graus ou níveis de racismo: individual racism, institutional racism, societal racism e civilizational racism. No presente trabalho ganham maior destaque o institutional racism ou racismo institucional, porquanto categoria à qual se relaciona o racismo
} 
Por ato de racismo ostensivo ${ }^{9}$, busca-se referir àqueles atos que são externalizados, conscientes e intencionais, praticados por indivíduo(s) de um grupo racial com o objetivo de ofender indivíduo(s) de outro grupo racial, em razão da raça. ${ }^{10}$ Já existe atualmente no Brasil um consenso socialmente estabelecido no sentido de que o racismo é inaceitável, o que, inclusive, impulsionou a tomada de uma série de medidas político-jurídicas, tais como: a ratificação e internalização da Convenção Internacional sobre a Eliminação de Todas as Formas de Discriminação Racial, a instituição do Estatuto da Igualdade Racial (Lei ${ }^{\circ}$ 12.288/2010) e a criminalização do racismo e da injúria racial.

Noutro giro, é frequente a observância do racismo velado ou dissimulado, isto é, de atos de discriminação não explícitos, na sociedade brasileira. Válido citar os resultados de pesquisa realizada pela Universidade de São Paulo, em 1988, sob a coordenação de Schwarcz, que denotam a forte presença do aspecto velado do racismo no Brasil: enquanto 98\% dos entrevistados negaram possuir qualquer preconceito de cor, $99 \%$ responderam afirmativamente quando indagados a) se conheciam alguém com preconceito de cor; e b) se teriam uma relação próxima com o sujeito preconceituoso (Schwarcz, 1996, p. 100). Existe não só uma rudeza implícita no racismo brasileiro como também a dificuldade dos brasileiros em se reconhecer no papel do discriminador.

A dificuldade só aumenta quando se migra para categorias de racismo estrutural como o racismo institucional e o racismo epistemológico. Essas modalidades, diferente do racismo individual, não se limitariam ao trato intersubjetivo, sendo mais abrangentes. É que, equivocadamente, o indivíduo, ao avaliar questões de racismo estrutural ou sistêmico, indaga-se se ele especificamente, enquanto indivíduo, seria capaz de inferiorizar outro

ambiental enquanto forma de discriminação, e o racismo epistemológico, que é espécie de civilizational racism ou racismo civilizacional.

${ }^{9}$ Traduzido do inglês overt racism.

${ }^{10}$ No original: "[...] is a public, conscious, and intended act by a person or persons from one race with the intent of doing damage to a person or persons of another race chiefly because of the race of the second person or persons" (Scheurich \& Young, 1997, p. 5) 
ser humano em virtude da sua cor ou raça. Ocorre que essa visão particularizada e incompleta não dá conta das formas estruturais de racismo, que transcendem o trato intersubjetivo e se manifestam em reflexos da coletividade. $^{11}$

É necessário, pois, que se desagregue a avaliação das formas de racismo estrutural - institucional e civilizacional - do plano individual, vez que tais categorias são objetivamente aferidas e sua caracterização não se vincula ao plano das intenções do agente que pratica o ato racialmente discriminatório. O racismo institucional, por sua vez, se verifica quando instituições ou organizações, inclusive educacionais, operam mediante procedimentos padrão que (intencionalmente ou não) prejudicam membros de determinados grupos raciais em relação aos membros da raça dominante (Scheurich \& Young, 1997, p. 5). ${ }^{12}$ Leve-se em conta que, historicamente, narrativas e produções científicas racistas - algumas das quais se expõe adiante - bem como processos políticos bem definidos, criaram e assentaram as bases para a manutenção de um sistema desigual de oportunidades e privilégios baseados na noção de raça (Solórzano \& Yosso, 2002). Daí advém ideias que passam a integrar um "senso comum" e são incorporados pelo imaginário social, herança da construção de um legado de privilégios raciais.

Atente-se para o fato de que a indeterminação ou não reconhecimento da relevância do fator "raça" como variável em pesquisas, sobretudo num país que tem um importante histórico de discriminação racial, fortalece a reprodução do racismo institucional. Outra categoria de

\footnotetext{
${ }^{11}$ Para Scheurich e Young, "researches, just like other members of this society, typically judge their own lack of racism based on personal evaluations that they do not, as an individual, have a negative judgment of another person just because that person is a member of a particular race. While this individualized, conscious, moral or ethical commitment to anti-racism is a significant and meaningful individual and historical accomplishment, the fact that it restricts our understanding of racism to an individualized ethical arena is a barrier to a broader, more comprehensive understanding of racism - for society and for researchers" (ibid., p. 5)

${ }^{12}$ Adaptado do inglês: "institutional racism exists when institutions or organizations, including educational ones, have standard operating procedures (intended or unintended) that hurt members of one or more races in relation to members of the dominant race [...]. Institutional racism also exists when institutional or organizational cultures, rules, habits or symbols have the same biasing effect" (ibid., p. 5)
} 
racismo apontada por Scheurich e Young (1997) é o societal racism, que se diferencia do racismo institucional por ser mais amplo, afetando a sociedade como um todo. Por definição, o societal racism se dá quando prevalecem premissas culturais, normas, conceitos, hábitos, expectativas, etc., que beneficiam um grupo racial em detrimento de outros grupos raciais. ${ }^{13}$ Parte da propagação e difusão de noções ou ideias, seja através da mídia, de práticas jurídicas, políticas públicas ou programas governamentais, que se incorporam ao imaginário social e passam a compor um "senso comum". ${ }^{14}$

Num nível mais radical - no sentido de nuclear -, íntimo e profundo, encontra-se o racismo civilizacional (civilizational racism), do qual exsurge o racismo epistemológico. A prática dessa forma de racismo emerge do nível cultural em que residem e se formam os pressupostos do pensamento social, tais como a ontologia, a epistemologia e axiologia, que tratam das preconcepções sobre a propriedades e natureza do ser, do conhecimento humano, da natureza e valores éticos ou morais. ${ }^{15} \mathrm{O}$ nível civilizacional, a que se referem Scheurich e Young (1997), seria o mais nuclear da cultura de determinado povo, o mais profundo, em que seriam formadas as noções que influenciam a compreensão de mundo e a forma como este é apreendido.

Há que se considerar que cada grupo étnico-racial possui uma origem e história próprias, esta última em constante desenvolvimento. À conta disso, reputa-se imperativo que os estudos críticos do direito utilizem

\footnotetext{
${ }^{13}$ Traduzido do inglês "Societal racism, then, can be said to exist when prevailing societal or cultural assumptions, norms, concepts, habits, expectations, etc. favor one race over one or more other races". (ibid., p. 6)

${ }^{14}$ Veja-se que, por exemplo, a noção mais difundida e propagada do que compõe o núcleo familiar adequado ou quais características formam o "cidadão de bem" é extraída de noções culturais dominantes e experiências históricas, que transcendem a trajetória de vida de cada um dos indivíduos membro dessa sociedade.

${ }^{15}$ A definição de Scheurich e Young, em inglês: “[...] epistemological racism comes from or emerges out of what we have labeled as the civilizational level - the deepest, most primary level of a culture of people. The civilizational level is the level that encompasses the deepest, most primary level of a culture of people. The civilizational level is the level that encompasses the deepest, most primary assumptions about the nature of reality (ontology), the ways of knowing that reality (epistemology), and the disputational contours of right and wrong or morality and values (axiology) - in short, presumptions about the real, the true, the good." (ibid., p. 6)
} 
lentes sensíveis às possíveis formas de racialização e discriminação de grupos impostas por classes dominantes, bem como à incorporação de noções discriminatórias e estereótipos presentes no imaginário social (Silva, 2015).

A interação global do mundo ocidental contou, desde o início, com o estabelecimento de relações de dominação que reinventaram o conceito de "raça", forçando a convivência ou coexistência espacial de grupos ou tribos originalmente distintas, mas que habitariam um mesmo território nacional. Esses grupos - indígenas, africanos, colonos e imigrantes europeus e asiáticos - possuíam diferentes maneiras de compreensão do mundo que variavam desde a relação com a terra à relação com a própria coletividade em que se inseriam. Uma consequência do processo de interação entre povos e da base de organização da sociedade imposta por esse modus operandi, é a incorporação da relação de dominação racial nas premissas e técnicas de interpretação da realidade, do modus vivendi da sociedade.

À luz do exposto, cumpre questionar a normatividade - na medida em que reflete falhas estruturais presentes na sociedade - e as formas pelas quais o Direito incorpora e estabiliza fenômenos sociais indesejáveis e até incompatíveis com direitos, princípios e objetivos constitucionalmente consagrados. ${ }^{16}$ Sob o prisma da Teoria Crítica da Raça, põe-se em evidência a importância de mecanismos epistemológicos frequentemente negligenciados ou descreditados, como narrativas em primeira pessoa, e questiona-se a falsa neutralidade da "cegueira de cor" ("color blindness") utilizada por organizações e instituições.

Sustenta-se que, em contraponto às epistemologias eminentemente brancas consagradas na Modernidade, faça-se o uso do que se chama de epistemologia colorida como negação a um modelo epistemologicamente

\footnotetext{
${ }^{16}$ Tais como: a dignidade da pessoa humana (art. $1^{\circ}$, inciso III, da CRFB), a erradicação da pobreza e das desigualdades sociais (art. $3^{\circ}$, III, da CRFB), a promoção do bem e a consequente negativa à todas as formas de discriminação (art. $3^{\circ}$, IV, da CRFB), o repúdio ao racismo (art. $4^{\circ}$, VIII, CRFB), o direito à igualdade (art. $5^{\circ}$, caput, CRFB). Na medida em que promove a institucionalização da desigualdade e do tratamento desigual a cidadãos igualmente reconhecidos, atenta-se também contra o princípio republicano e o Estado Democrático de Direito.
} 
discriminatório. Essa escolha decorre da denúncia - promovida pela Teoria Crítica da Raça - dos males sociais advindos de indeterminações legais somada à crítica à hegemonia da história triunfalista e o consequente abafamento de outras narrativas. O uso de metodologias e epistemologias que reconheçam a existência do racismo epistemológico - e se esforcem em desapegar das práticas institucionalizadas que o sustentam e adotar novas perspectivas - parte da constatação de que existe uma relação entre o poder e a construção de papeis sociais, de hábitos sociais e padrões de comportamento - por vezes inconscientes.

A Modernidade foi forjada a partir da colonização europeia e de um sistema de expansão territorial que consagraria a supremacia branca. ${ }^{17}$ As sociedades gestadas no Novo Mundo já o seriam a partir noção de hierarquia racial, seus sistemas fundamentados numa visão de mundo eminentemente branca que definiria uma série de normas e conceitos, como a noção de propriedade, por exemplo. É esse sistema de supremacia branca "que faz com que o racismo, de um lado, implique na subalternização e destituição material e simbólica dos bens sociais que geram respeito e estima aos negros - ciclo de desvantagens -, de outro, coloque os brancos imersos em um sistema de privilégios assumido como natural" (ibid., p. 66).

Veja-se que, na medida em que se torna clara a existência de uma hierarquia racial institucionalizada, mais evidente é a necessidade de adoção de uma perspectiva crítica e transdisciplinar na análise das normas jurídicas e do seu potencial discriminatório. Assim é que a Teoria Crítica da Raça parte do pressuposto de que o racismo não seria uma anormalidade, mas uma prática cotidiana da sociedade estadunidense. Traça-se um paralelo com a trajetória brasileira: o racismo também no Brasil se

\footnotetext{
${ }^{17}$ Consigne-se que não se pretende esgotar argumentos que denotem a existência de um sistema de supremacia branca ou de subalternização de grupos raciais historicamente prejudicados por práticas institucionais, mas destaca-se o seguinte apontamento: "A raça branca, o que Stanfield (1985) tem chamado de 'uma privilegiada parcela da população' (p. 389), tem inquestionavelmente dominado a civilização ocidental durante toda a Modernidade (centenas de anos). Quando qualquer grupo - com uma extensa e complexa civilização - significativamente domina outros grupos por centenas de anos, os modos do grupo dominante (suas epistemologias, ontologias, axiologias) não só se tornam os moldes dominantes de civilização, mas esses moldes também se tornam tão profundamente enraizados que não tipicamente vistos como 'naturais' ou normas apropriadas ao invés de construções sociais historicamente desenvolvidas." (Stanfield, 1985 apud Scheurich \& Young, 1997, p. 7)
} 
manifesta em comportamentos culturalmente enraizados e naturalizados. (Silva, 2015)

Afirmar a existência do racismo epistemológico não significa dizer que os pesquisadores e estudiosos estariam praticando atos de racismo ostensivo ou velado. Como visto, há que se desvincular a análise das formas estruturais de racismo do indivíduo, dado seu caráter sistêmico. O que se quer dizer é que boa parte das epistemologias consagradas e veiculadas na academia decorrem do contexto histórico-cultural da raça dominante, porquanto refletem e reforçam esse mesmo contexto e grupo racial ao passo que exclui outras formas de apreensão do conhecimento (Scheurich \& Young, 1997). A crítica tem especial impacto na investigação do racismo ambiental, pois ultrapassar somente a verificação da injustiça ambiental requer a adoção de uma perspectiva que põe o fator "raça" como variável central de análise.

Merece atenção uma diferença crucial no trato da questão entre Brasil e Estados Unidos. Muitos dos obstáculos que o estudo do racismo ambiental encontra no Brasil têm origem no mito da democracia racial. A tese é responsável por fortalecer a crença na relação harmoniosa entre as raças na sociedade brasileira, glorificando a inexistência de tensões raciais como fruto de um processo bem sucedido de mestiçagem e assimilação étnica. Por outro lado, o contexto de embate explícito do apartheid estadunidense permite que seja ultrapassado o argumento de inexistência da discriminação racial e que o tema seja ampla, aberta e publicamente debatido.

Impende notar que há um diálogo entre as noções fornecidas pela Teoria Crítica da Raça e a concepção do mito da democracia racial brasileira. Enquanto o mito da democracia racial lê atos de discriminação racial como anomalias sociais, a TCR defende que tais práticas se relacionariam com aspectos estruturais da sociedade, pelo que não seriam extraordinárias. Questiona-se, ainda, o argumento da meritocracia como justificador da substancial carência de negros figurando em posições de 
poder ou cargos elevados, através do que se fortaleceria a crença na superioridade e merecimento do grupo dominante. É que o argumento carece de contextualização histórica, o que promove, havendo somente a garantia à igualdade formal, a ausência de igualdade material. Finalmente, observe-se que o Brasil, o país referência para o mito da democracia racial, foi o mesmo país que por décadas reforçou políticas de branqueamento da população, fortalecendo a máxima de que "quanto mais branco melhor e quanto mais preto pior" (Silva, 2015, p. 67).

Um olhar informado pelas premissas da Teoria Crítica da Raça já vem sendo empregado por alguns ativistas e pesquisadores dedicados ao combate do racismo ambiental no Brasil. Contudo, há ainda disputa de espaço para a adoção de lentes de análise que não desconsiderem outras formas de discriminação - racial, de gênero, religiosa, por orientação sexual - sob a variável "classe". Com efeito, não é desejável, na averiguação e combate das formas de injustiça ambiental, suprimir a existência de múltiplas formas de discriminação, sob pena de se desconsiderar a sobreposição de graus diferenciados de violência e reproduzir a crença na distribuição democrática de externalidades, igualmente conferindo tratamento desproporcional a grupos subalternizados.

\subsection{Racismo Ambiental: apresentação do conceito}

O conceito de racismo ambiental é concebido a partir de protestos da população negra norte-americana que, no seio do movimento por justiça ambiental, buscava visibilizar o grau desproporcional de poluição industrial a que era submetida. É de se notar que os primeiros movimentos sociais preocupados com a saúde ambiental nos EUA teriam surgido, em princípio, nas mais altas camadas sociais, em setores eminentemente brancos e de classe média e alta (Bullard, 2000). Conquanto seja possível observar que àquele tempo já se encontrava a pleno vapor o movimento por direitos civis, verificou-se que é a partir do movimento por justiça ambiental que há a 
união da agenda de movimentos ambientalistas e de pautas concernentes à luta por equidade social e contra a discriminação racial.

Faz-se mister, desta feita, distinguir o posicionamento defendido pelos que ora se designa como "ambientalistas tradicionais", cujo movimento teria se iniciado ao fim do século XIX, daquele adotado pelo que se chama de "ambientalistas modernos". ${ }^{18}$ É que os primeiros teriam como principais pautas questões como o lazer, a preservação da vida animal selvagem, a proteção de recursos naturais, bem como a redução da poluição e regulação da atividade industrial, ao passo que os segundos, vislumbrando a questão ambiental sob a ótica da justiça social, teriam preocupações voltadas para a garantia e efetivação de direitos civis básicos, equidade social, combate à discriminação institucional, dentre outros.

Enquanto a questão ecológica preocupou a maioria da população envolvida no movimento ambiental tradicional, com certo grau de prioridade em diversos segmentos, questões relativas a equidade social e a modalidade de distribuição dos impactos ambientais permaneceram negligenciadas ao longo dos anos. Com efeito, as indústrias passaram a destinar os dejetos poluentes às comunidades que tinham menor capacidade de resistir a sua atuação, quais sejam, aquelas em que a população acreditava não ter poder de ação, que possuíam menores índices de desenvolvimento socioeconômico e pertenciam, majoritariamente, a minorias étnicas, conforme se comprovou com uma série de estudos desenvolvidos posteriormente por entidades preocupadas em ouvir e

\footnotetext{
${ }_{18}$ Ambas as nomenclaturas utilizadas foram adaptadas dos estudos de Bulllard (2000; 2002), de modo que por "ambientalistas tradicionais" deve-se compreender o movimento ambientalista norte-americano em favor da conservação ambiental surgido na década de 1890, em oposição aos "ambientalistas modernos" cujas raízes remetem o movimento pelos direitos civis da década de 1960. Em sua obra, o autor menciona três grupos distintos: environmentalists, social justice advocates e economic boosters. Contudo, optou-se no presente trabalho por aludir-se somente às duas primeiras categorias, correspondendo a primeira ao que se chama de "ambientalistas tradicionais" e a segunda aos aqui chamados "ambientalistas modernos", respectivamente. A fim de completamente esclarecer as definições, vale explicitar que, para Bullard, "environmentalists are concerned about leisure and recreation, wild life and wilderness presenvation, pollution abatement and industry regulation", enquanto "social justice advocates' major concerns includes basic civil rights, social equity, economic mobility and institutional discrimination", o que se traduziu livremente no corpo do texto. (Bullard, 2000, p. 9)
} 
investigar as demandas de populações menos favorecidas pelo sistema burocrático e jurídico norte-americano.

Se por um lado grande parte da população branca de classe média clamava em prol da saúde do meio ambiente, por outro, havia uma grande produção de passivos ambientais ${ }^{19}$ oriundos não só da produção industrial, mas do modus operandi da sociedade de consumo que vinha se implementando. Percebeu-se o fenômeno chamado por sociólogos ambientalistas de "not in my backyard", o qual se traduz livremente para "não no meu quintal". A razão de ser da observação desse fenômeno, segundo Bullard (2002), era o fato de que, dado o clima político da época, haja vista que os dejetos não tinham destinação adequada, era provável que toda sorte de poluição industrial, de fato, atingisse o quintal de alguém. De acordo com o autor, a resposta ao fenômeno foi a destinação, como regra, dos ônus ambientais a comunidades negras, isto é, "the place-in-blacks'backyard principle".

O movimento por justiça ambiental, então, viria a estabelecer relações com o movimento pelos direitos civis, vez que o combate à discriminação institucional e a promoção da equidade social eram pautas comuns a ambos. Há que se notar, ademais, que o movimento por justiça ambiental surge essencialmente a partir da constatação de que minorias étnicas, em especial a população negra norte-americana, suportavam um desproporcional índice de exposição a externalidades ambientais negativas.

Nessa esteira, cunhou-se o conceito de injustiça ambiental, o qual se entende como:

\footnotetext{
"o mecanismo pelo qual sociedades desiguais destinam a maior carga dos danos ambientais do desenvolvimento a grupos sociais de trabalhadores, populações de baixa renda, grupos raciais discriminados, populações marginalizadas e mais vulneráveis" (Herculano, 2008, p. 2.).
}

\footnotetext{
${ }^{19}$ Por "passivos ambientais" designa-se a presença de externalidades negativas e a existência de danos provocados ao meio ambiente lato sensu, sejam provocados por empreendimentos de ordem econômica ou de outra natureza. Cumpre elucidar que não se atribui à expressão, no corpo deste trabalho, o valor específico de obrigação de curto prazo em prol de ações que visem a reparação ou atenuação de danos ambientais produzidos por determinada empresa. Portanto, não se utiliza a expressão no sentido técnico-jurídico do termo.
} 
A injustiça ambiental, portanto, pode ser descrita como o tratamento díspar de determinado grupo ou comunidade com base na raça, classe, ou outra característica distintiva, pelo que se evidencia sua íntima relação com o racismo institucional e a razão por que no seio do movimento por justiça ambiental norte-americano se incorpora a luta contra o racismo ambiental.

Após a investigação de casos emblemáticos e da realização de diversas pesquisas ${ }^{20}$ - tanto por iniciativas de organizações da sociedade civil quanto governamentais -, a Comissão por Justiça Racial (Comission for Racial Justice) verificou, em 1987, que o fator determinante na alocação de passivos ambientais consistia primordialmente no elemento étnico-racial da comunidade local, em detrimento do índice socioeconômico. Isto é, avaliou-se empiricamente que, concorrendo a vulnerabilidade socioeconômica e o fator racial, vencia este último como critério determinante de distribuição dos ônus ambientais. Cunhou-se, então, o conceito de justiça ambiental, perspectiva epistemológica a nortear o presente estudo, que, de acordo com a United States Environmental Protection Justice, consiste em:

"Tratamento justo e envolvimento significativo de todas as
pessoas independentemente de raça, cor, nacionalidade ou
classe econômica, no que diz respeito ao desenvolvimento,
implementação e execução das leis ambientais, regulações e
políticas. Por tratamento justo se tem que nenhum grupo de
pessoas, inclusive grupos raciais, étnicos ou socioeconômicos,
devem suportar uma parcela desproporcional de consequências
ambientais negativas provenientes de operações industriais,
municipais ou comerciais, ou da execução de programas e
políticas federais, estaduais, locais e tribais". (Bullard, 2002, p.
$4)^{21}$

${ }^{20}$ A título exemplificativo, vale a menção ao caso Love Canal e ao caso Warren County, ambos importantíssimos em conferir visibilidade e alavancar politicamente a luta contra o racismo ambiental, tanto do ponto de vista da mobilização social atingida como do impacto do cenário político nacional. Dentre a série de estudos produzidos naquele país, merecem destaque o "Toxic Waste and Race in the United States", que foi o primeiro estudo nacional produzido pela Comission for Racial Justice, e o conduzido pela United States General Accounting Office, em 1983, a respeito da alocação de dejetos de material perigoso em Warren County.

${ }^{21}$ No original: "fair treatment and meaningful involvement of all people regardless of race, color, national origin, or income with respect to the development, implementation, and enforcement of environmental laws, regulations and policies. Fair treatment means that no group of people, including racial, ethnic, or socio-economic groups, should bear a disproportionate share of the negative environmental consequences resulting from industrial, municipal, and commercial operations or the execution of federal, state, local and tribal programs and policies". (Bullard, 2002, p. 4). 
As pesquisas conduzidas nos Estados Unidos referentes a alocação de dejetos no período de 1978-199122, concluíram pela preferência em depositá-los em localidades próximas a comunidades negras, latinas ou indígenas em pelo menos 10 estados da federação ${ }^{23}$. A análise conduzida por Bullard (2000) nos EUA concluiu haver preferência em submeter comunidades negras a piores condições ambientais, mesmo quando essas comunidades eram de classe média, o que demonstrou o reduzido impacto do fator socioeconômico na tomada de decisão em relação ao fator racial, ainda que não se exclua completamente influência daquele.

Segundo Bullard, o racismo ambiental

"se refere a políticas, práticas ou diretrizes ambientais que afetam diferentemente ou de forma desvantajosa (seja intencionalmente ou não) indivíduos, grupos ou comunidades com base na cor ou raça, podendo ser reforçadas por instituições governamentais, jurídicas, econômicas, políticas e militares". (ibid., p. 2) ${ }^{24}$

Tendo em conta o teor da definição do conceito de racismo ambiental, o autor defende se tratar de uma forma institucionalizada de discriminação, a qual consiste em "ações ou práticas realizadas por membros de grupos (raciais ou étnicos) dominantes que tem particular impacto desvantajoso em membros de grupos (raciais ou étnicos)

\footnotetext{
${ }^{22}$ Em 1978, houve o emblemático caso de contaminação química em Love Canal, Niagara, estado de Nova Iorque. Em 1982, descobriu-se que um aterro para depósito de solo contaminado seria instalado numa comunidade negra em Warren County, Carolina do Norte. Em 1983, num estudo conduzido pela United States General Accounting Office, constatou-se que três em quatro aterros de material perigoso havia sido alocado em comunidades negras, embora estes correspondessem a aproximadamente apenas $20 \%$ da população da região, que abrangia oito estados norteamericanos. Em 1991, a Greenpeace aferiu que, no sudeste de Chicago, num contingente populacional de cento e cinquenta mil pessoas, dentre as quais oitenta e um por cento correspondia a negros e latinos, estavam localizados cinquenta aterros de lixo tóxico, cem fábricas e cento e três depósitos abandonados de lixo tóxico. (Herculano, 2008, p.3)

${ }^{23}$ Ao longo do período descrito foram conduzidos estudos que descobriram a preferência pela alocação de ônus ambientais em sítios próximos ou contidos em comunidades de minorias étnicas nos Estados de Nova Iorque, Carolinas do Norte e do Sul, Alabama, Flórida, Kentucky, Mississipi, Louisiana (parte sul), Chicago (sudeste), Califórnia, Los Angeles (na zona leste, de ocupação latina) e em mais de 36 reservas indígenas. (ibid., p. 2-3).

${ }^{24}$ No original: "refers to environmental policies, practices, or directives that differentially affect or disadvantage (whether intentionally or unintentionally) individuals, groups, or communities based on race or colour (...) is reinforced by governmental, legal, economic, political and military institutions." (Bullard, 2002, p. 2).
} 
subordinados" (ibid., p. 2). ${ }^{25}$ Com efeito, vale dizer que o racismo institucional se manifesta através de mecanismos, ações, estratégias, políticas, decisões, etc., de instituições públicas e de agentes privados, explicitamente ou não, que imponham tratamento diferencial ou inferiorizem a populações de minorias raciais ou étnicas. ${ }^{26}$

Disso decorrem diversos obstáculos à análise do racismo ambiental sobretudo no Brasil - já que a discriminação institucional pode ser pouco aparente e sua demonstração normalmente impõe a análise de estatísticas racialmente específicas quanto ao órgão sob exame, muitas vezes indisponíveis ou inexistentes. E não é só. Há que se considerar também o caráter não pessoal, individualizado, dessa ordem de discriminação, que é mais frequentemente - sistêmica, podendo, portanto, ser internalizada, incorporada e naturalizada por discursos amplamente aceitos pela sociedade.

Não se trata de averiguar se o indivíduo tomador da decisão que produz o racismo ambiental o fez intencionalmente ou não, ou de levantar a hipótese da existência de uma conspiração de determinado grupo racial para deliberadamente condenar outros grupos raciais a condições precárias de vida. O que se avalia são dados da realidade, reflexos de falhas estruturais no âmago do núcleo informador da sociedade.

Pertinente realizar alguns apontamentos antes de se proceder à análise do desenvolvimento de teorias racistas e ao debate quanto ao racismo institucional e ambiental no Brasil. Tendo-se que o racismo ambiental, enquanto espécie de discriminação étnico-racial institucional, não pressupõe que necessariamente um grupo dominante deliberada e intencionalmente pretende produzir a discriminação, "mesmo que as instituições sejam administradas, governadas por pessoas não racistas ou

\footnotetext{
${ }^{25}$ No original: "actions or practices carried out by members of dominant (racial or ethnic) groups that have differential and negative impact on members of subordinate (racial and ethnic) groups" (ibid., p. 2).

${ }^{26}$ Por exemplo, "há racismo ambiental quando um órgão, entidade, organização ou estrutura social cria um fato social hierárquico - estigma visível, espaços sociais reservados -, mas não reconhece as implicações raciais do processo" [de criação do mesmo]. (Santos, I. A. A., 2015, p. 27).
} 
crentes em teorias racistas, elas podem estar sujeitas ao racismo inconsciente" (Santos, I. A. A., 2015, p. 25).

Além disso, observe-se que ainda que haja consenso quanto a existência do racismo, as formas de discriminação institucional, por natureza, guardam dificuldades de comprovação - o que no Brasil se agrava por barreiras metodológicas -, mas que podem ser visibilizadas a partir de indicadores que denotam situações de inferioridade ou desigualdade imposta a população negra. Tais barreiras em muito encontram fundamento no racismo epistemológico, eis que a formulação de todo um sistema de apreensão e tratamento de dados é informado por uma perspectiva forjada de acordo com o saber da cultura dominante.

A qualificação do racismo ambiental como forma institucionalizada de racismo é bem explicada por Herculano nos seguintes termos:

"Os mecanismos e processos sociais movidos pelo racismo ambiental naturalizam as hierarquias sociais que inferiorizam etnias e percebem como vazios os espaços físicos onde territórios estão constituídos por uma população que se caracteriza por depender estreitamente do ecossistema no qual se insere. Em suma, trata-se aqui da construção e permanência de relações de poder que inferiorizam aqueles que estão mais próximos da natureza, chegando a torna-los invisíveis. [...] Assim, nosso racismo nos faz aceitar a pobreza e a vulnerabilidade de enorme parcela da população brasileira, com pouca escolaridade, sem renda, sem políticas sociais de amparo e de resgate, simplesmente porque naturalizamos tais diferenças, imputando-as a 'raças'." (Herculano, 2008, p. 17).

Como se verá em subcapítulo próprio, a luta contra o racismo ambiental guarda íntima relação com o movimento pelos direitos civis norte-americano. É bem de ver que

"[...] a luta pelos direitos civis nos EUA, a luta contra o apartheid na África do Sul e o fim do colonialismo nos países africanos e asiáticos representaram mudanças profundas nos estudos sobre o racismo no mundo. Reconheceu-se que as instituições, práticas administrativas e estruturas políticas e sociais podiam agir de maneira adversa e racialmente discriminatória ou excludente. Também se reconhecia que os processos discriminatórios têm vida própria causalmente, de modo independente da ação de uma pessoa individualmente racista. O conceito de racismo foi ampliado para cobrir as formas de racismo institucional e racismo estrutural. $\mathrm{O}$ racismo passou a ser identificado como uma situação que poderia ocorrer independentemente da vontade das pessoas, e se 
reconheceu que certas práticas, realizadas por instituições, não têm atitudes, mas podem certamente discriminar, criar obstáculos e prejudicar os interesses de um grupo por causa de sua raça, de sua cor." (Santos, I. A. A., 2015, p. 23)

Finalmente, antes de se passar à análise mais aprofundada do racismo ambiental no Brasil há que se ter em conta dois importantes elementos: em primeiro lugar, note-se que o conceito de racismo ambiental emerge da aproximação entre a preocupação ambiental e a luta por equidade social; em segundo lugar, que o meio ambiente não se limita a questões ecológicas, englobando não só o meio ambiente natural como também o artificial. Assim sendo, consigne-se que a proteção ambiental não só comporta a não submissão à níveis insalubres de poluição, como o acesso equitativo a condições mínimas de moradia, saneamento básico e mobilidade urbana.

\subsection{Movimento por Justiça Ambiental: da gênese à internacionalização}

Como visto, há inegável pluralidade de perspectivas epistemológicas no contexto dos movimentos sociais ambientalistas. ${ }^{27}$ Esclarece-se, de antemão, que a perspectiva adotada no presente trabalho não se limita a avaliar as mazelas decorrentes da questão ambiental somente a partir do ponto de vista técnico-científico ${ }^{28}$, mas debruça-se também sobre os elementos sociopolíticos concernentes à questão. Cuida-se de adotar instrumentos de análise cunhados a partir da ebulição do movimento por justiça ambiental, que logrou visibilizar aspectos influenciadores da distribuição dos ônus ambientais tanto em nível nacional quanto global.

\footnotetext{
${ }^{27}$ No item supra foram apresentadas duas perspectivas: a dos "ambientalistas tradicionais" e dos "ambientalistas modernos". Admite-se, ainda, existirem apostas em outros olhares de enfrentamentos da problemática ambiental.

${ }^{28}$ Explica-se: cuida-se aqui não somente de avaliar o grau de impacto das mais diversas formas de poluição ambiental ao meio ambiente ecológico, mas também vislumbrar em que medida questões sociais e políticas afetam o grau de exposição de determinados povos a tipos específicos de ônus ambientais. Parte-se da premissa de que externalidades ambientais negativas, especialmente no contexto urbano, não atingem a todos de maneira igualitária e democrática, mas afeta de forma distinta e desproporcional grupos específicos.
} 
Historicamente, os grupos ambientalistas negros norte-americanos teriam surgido a partir de articulações desenvolvidas em organizações sociais já estabelecidas, tais como as igrejas e outras formas de associações voluntárias que decidiriam se opor às formas de discriminação racial e de injustiça social. Isto, em função do precário grau de representação políticas de seus interesses nas entidades ambientalistas tradicionais, que não consideravam a existência de disparidades no nível de exposição de diferentes grupos sociais a passivos ambientais. Ao revés, entendia-se que os males da questão ambiental afetavam igualmente a todos os indivíduos.

Posteriormente, grupos de ação social passaram a incorporar às suas pautas questões de equidade social, ampliando sua base de apoio e esfera de influência, com o objetivo de atrair e conferir algum grau de representatividade àquelas demandas. Não seguiu despercebido o fato de que vinham sendo reiteradamente criados sítios de alocação de lixo tóxico, aterros sanitários, assim como outros tipos de depósito de material indesejado, em regiões majoritariamente habitadas por populações com menores chances de resistir tanto a decisões estatais como a agentes econômicos poluidores. Desse modo, comunidades de minorias étnicas e pobres terminavam por arcar com problemas ambientais de maneira desproporcional quando comparadas com comunidades não pertencentes a tais grupos.

O movimento por equidade social se tornaria, então, uma extensão do movimento pelos direitos civis, surgido no sul dos Estados Unidos e potencializado na década de sessenta, com o enfrentamento da discriminação racial. Não por coincidência, é da mesma região que nasce o movimento por equidade social, eis que o tratamento desigual era ainda mais acentuadamente sentido em comunidades negras e latinas sulistas.

Embora a cronologia de Bullard (2002) demonstre que inicialmente não teria ocorrido grande aproximação do ativismo negro à questão da poluição ambiental, uma vez iniciado o movimento por equidade social houve efetivo esforço pela união daqueles movimentos sociais: buscou-se 
forjar alianças com entidades de classe, de modo que se pudesse compatibilizar as agendas ambientais com a justiça e equidade social. Além disso, foram realizadas conferências e workshops com vistas a estreitar os laços entre as organizações, de modo que a pretensão da justiça ambiental ganhasse cada vez maior espaço dentro do movimento pelos direitos civis.

É possível que se leia o surgimento do movimento por justiça ambiental justamente como a síntese do processo de aproximação e intercâmbio entre a agenda ambientalista moderna e o movimento negro, pelo que a agenda de entidades ambientais passa a integrar demandas em prol da equidade social com status de direito civil. Segundo Scholberg (2009), seria possível identificar duas correntes dentro desse movimento ambientalista: o "movimento contra a contaminação tóxica" e o "movimento contra o racismo ambiental" (Scholberg, 2009, p. 46). ${ }^{29} \mathrm{~A}$ expressão justiça ambiental ganharia maior notoriedade política a partir do segundo (Rammê, 2012), eis que a perspectiva emerge eminentemente a partir de mobilizações que se opuseram a casos locais de racismo ambiental.

Dois casos emblemáticos de contaminação fortaleceram as bases do movimento por justiça ambiental nos EUA, conferindo visibilidade à questão e mobilizando maior contingente populacional nos protestos, além de promover ainda maior estreitamento dos laços com o movimento pelos direitos civis: os casos Love Canal e Warren County.

O caso Love Canal se passou em Niagara Falls, no Estado de Nova Iorque. Inicialmente elaborado em 1892 e posteriormente abandonado - em 1920 -, o projeto Love Canal consistia na construção de um canal fluvial que conectaria as partes alta e baixa do rio Niagara. $\mathrm{O}$ espaço foi vendido na primeira metade do século XX e transformado em um depósito de lixo que abrigava resíduos de dejetos químicos industriais e bélicos. O depósito ficou ativo durante três décadas, transformando-se, anos depois, na base de

\footnotetext{
${ }^{29}$ A distinção terminológica não indica uma cisão no movimento, mas denota a especialização que as articulações e alianças políticas permitiam, à luz da diversidade da natureza das denúncias que emergiam.
} 
construção de uma escola primária e de diversas residências. Em meados da década de setenta, a comunidade local observou a ocorrência de diversas doenças.

De acordo com moradores da região, "as crianças não mais podiam brincar fora de casa porque as solas de seus pés ficavam queimadas" (Rammê, 2012, p. 14) e "as árvores morriam na região e que os focinhos dos cães queimavam quando em contato com a terra do quintal das casas" (ibid., p. 14). Em virtude da ocorrência de numerosos casos de aborto espontâneo, além do nascimento de cerca de duzentos de bebês com anomalias genéticas, o Departamento de Saúde determinou que fossem evacuados do local todas as gestantes e crianças de até dois anos de idade.

Diante da situação, os moradores da região se organizaram e fundaram a Love Canal Homeowners Association ${ }^{30}$, com a finalidade de pressionar autoridades públicas e constituir fundos de auxílio aos moradores locais. Efetivamente constatada a existência de riscos concretos à saúde da população local, encerrou-se o caso com a compra das residências e a realocação da comunidade pelo governador do Estado. O caso ganhou repercussão e gerou grande impacto político - no que exemplifica o caráter difuso das formas de organização da sociedade norte-americana contra os casos de racismo ambiental.

Outro caso bastante notório se passou em Warren County, Carolina do Norte, cuja população de dezesseis mil habitantes era majoritariamente negra e vivia em condições de extrema pobreza. Em 1982, o governo do Estado decidiu implantar no local um depósito para resíduos de bifenilpoliclorado $^{31}$, o que provocou o surgimento de protestos pacíficos pela população. A mobilização alcançou, então, visibilidade e apoio nacional, difundindo amplamente o movimento. No mesmo ano, ocorreu o primeiro protesto nacional contrário ao racismo ambiental.

\footnotetext{
${ }^{30}$ Em tradução livre: Associação de Proprietários de Casas em Love Canal.

${ }^{31}$ Substância utilizada em sistemas de produção industrial que apresenta riscos à saúde humana e que podem, inclusive, contaminar o solo e a água. Uma vez absorvida pelo organismo, pode ser transportada pela corrente sanguínea e provocar danos ao fígado, bem como ocasionar problemas de pele, oculares, dentre outros.
} 
No ano seguinte, a U.S. General Accounting Office conduziu um estudo $^{32}$ com o fito de averiguar a existência ou não de uma relação entre a alocação de depósitos de resíduos tóxicos ou perigosos e o caráter socioracial das comunidades em que eram comumente instalados. ${ }^{33}$ Os resultados obtidos demonstraram que três dentre quatro aterros de material perigoso havia sido alocado em comunidades negras, a despeito da quantidade de negros na área objeto do estudo corresponder a somente vinte por cento da população total. Evidenciou-se, com o referido estudo, a predominância do elemento racial sobre o caráter socioeconômico como determinante da escolha locacional. ${ }^{34}$

Ademais da análise da escolha locacional para diversos sítios de alocação de poluentes diversos, como materiais tóxicos e dejetos, foram avaliadas as áreas de maior precariedade e saneamento básico e distribuição de água, por exemplo. Verificou-se que as localidades mais sujeitas aos respectivos abusos ambientais eram aquelas ocupadas por minorias étnicas. Já empiricamente demonstrada a identidade geográfica entre as áreas de maior privação de serviços públicos, sociais e do pleno gozo da proteção ambiental, cunhou-se o conceito de racismo ambiental nos termos já apresentados.

Visibilizados sucessivos casos de contaminação, na década de 80 o governo norte-americano promulgou uma nova lei federal de proteção ambiental, além de promover a criação de um fundo cujos recursos se destinariam a indenização e recuperação de comunidades atingidas. ${ }^{35}$ Além disso, houve significativo avanço do ponto de vista da participação

\footnotetext{
${ }^{32} \mathrm{O}$ título do estudo produzido era Siting of harzadous waste landfills and their correlation with racial and economic status surrounding communities.

${ }^{33}$ A região objeto do referido estudo abrangia os Estados do Alabama, Carolinas do Norte e do Sul, Flórida, Geórgia, Kentucky, Mississipi e Tennessee.

${ }^{34}$ Merece menção também o caso Cancer Alley, apresentado por Herculano (2008), que expõe o fato da alocação do maior aterro comercial de lixo tóxico do país estar localizado numa região em que a população negra corresponderia a noventa por centro da população total.

${ }^{35}$ Dentre os casos que inspiraram a legislação em comento é possível destacar os de "leucemia infantil em Woburn, Massachussets; más-formações congênitas em San José, Califórnia; ocorrência de crianças sem cérebro em Brownsville, Texas; câncer pancreático e cânceres no sistema nervoso de crianças vizinhas à fábrica da Kodak, em Rochester, Nova York" (HERCULANO, 2001, p. 215-238)
} 
democrática da população e do direito à informação com a promulgação do The Community Right-to-know Act, que conferia à comunidade local o direito ser previamente informada acerca de empreendimentos que poderiam ser instalados na região.

A corroborar os estudos já realizados, a Comissão por Justiça Racial foi igualmente capaz de verificar que o fator determinante para a alocação de passivos ambientais nos Estados Unidos consistia principalmente no caráter étnico ou racial da comunidade local, mais do que o índice socioeconômico dos residentes. ${ }^{36}$ No mesmo sentido, tanto as pesquisas conduzidas por Bullard (2000) como diversas outras realizadas nos EUA entre os anos de 1978 e 1991 apontaram que eram preferencialmente submetidas a ônus ambientais desproporcionais comunidades negras, latinas ou indígenas. ${ }^{37}$

Havendo a contínua exposição de casos e considerando o progressivo aumento do apoio popular ao movimento por justiça ambiental e à luta contra o racismo ambiental, as discussões, pautas e agendas levantadas começaram a ganhar notoriedade no cenário internacional. Intensificaramse as discussões a respeito das relações forjadas entre raça, meio ambiente e pobreza, com a elaboração de estudos que buscavam novos instrumentos e variáveis de análise da problemática ambiental, eis que o método até então consagrado impossibilitava aferir os graus de equidade social.

Conforme defendem Acserald, Mello e Bezerra

"Nesse novo tipo de avaliação, a pesquisa participativa envolveria, como co-produtores do conhecimento, os próprios grupos sociais ambientalmente desfavorecidos, viabilizando uma integração analítica apropriada entre os processos

\footnotetext{
${ }^{36}$ Toxic Waste and Race in the United States foi o primeiro estudo nacional produzido pela Comission for Racial Justice. Dedicava-se a aferir características demográficas das áreas de alocação de depósitos de dejetos. O relatório resultante concluiu que a variável determinante no processo de alocação dos sítios de dejetos era, efetivamente, a característica do ponto de vista étnico-racial da comunidade que seria submetida ao ônus ambiental, eis que superava outras variáveis tais como o indicador socioeconômico da população ou o valor imobiliário.

${ }^{37}$ De acordo com os dados apresentados por Bullard (2000) em Dumping in Dixie: race, class and environmental equality, seria inegável a predominância da variável "raça" na escolha, visto que se aferiu a preferência em submeter comunidades de minorias étnicas a piores condições ambientais mesmo quando, comparativamente às alternativas, essas comunidades tinham indicador socioeconômico mais elevado.
} 
biofísicos e sociais. Postulava-se, assim, que aquilo que os trabalhadores, grupos étnicos e comunidades residenciais sabem sobre seus ambientes deve ser visto como parte do conhecimento relevante para a elaboração não discriminatória das políticas ambientais" (Acserald et al, 2009, p. 22 )

Em 1991, a Greenpeace aferiu que, no sudeste de Chicago, num contingente populacional de cento e cinquenta mil pessoas, dentre as quais oitenta e um por cento correspondia a negros e latinos, estavam localizados cinquenta aterros de lixo tóxico, cem fábricas e cento e três depósitos abandonados de lixo tóxico. ${ }^{39}$ No ano seguinte, após estudos, o National Law Journal afirmou que haveria uma divisão racial na alocação de dejetos tóxicos no país, bem como havia também distinção quanto às penalidades aplicadas aos infratores da legislação ambiental. ${ }^{40}$ Levou-se em conta dados fornecidos pela Environmental Protection Agency (EPA) concernentes a um total de 1.177 (mil, centro e setenta e sete) sítios de dejetos, que serviram de amostra.

A partir da análise efetuada, mais uma vez se comprovou empiricamente que a referida divisão não se dava em razão do índice socioeconômico das comunidades afetadas - variável que, quando posta no centro da análise, revelava existir uma diferença média de apenas 3\% (três por cento) no valor das indenizações impostas. Por outro lado, observou-se que as penalidades aplicadas aos agentes poluidores por infrações cometidas em comunidades majoritariamente brancas eram aproximadamente cinco vezes mais altas quando comparadas a comunidades negras (Bullard, 1994).

\footnotetext{
${ }^{38}$ A perspectiva com a qual alguns autores analisam a temática da injustiça ambiental no Brasil em certa medida se alinha à adotada no presente trabalho, que advoga o uso de uma "metodologia colorida", sob o paradigma da justiça ambiental e da Teoria Crítica da Raça. Desse modo, atentase à possibilidade de determinados levantamentos técnicos e científicos, bem como a produção de determinados dados, serem influenciados por uma perspectiva racial discriminatória. Por essa razão, foram também utilizadas fontes de pesquisa que consideram fontes frequentemente negligenciadas pela epistemologia dominante. Sobre "metodologia colorida" ver Scheurich e Young (1997).

${ }^{39} \mathrm{O}$ resultado é apresentado por Herculano (2008, p. 3).

40 "There is a racial divide in the way the US government cleans up toxic waste sites and punishes polluters. White communities see faster action, better results and stiffer penalties than communities where blacks, Hispanics and other minorities live. This unequal protection often occurs whether the community is wealthy or poor" (Cole \& Foster, 2001, p. 57).
} 
Reputa-se evidente, pois, a insuficiência da proteção tão somente jurídico-formal dessas populações sem que se façam presentes instrumentos que efetivamente assegurem a tutela do direito ao meio ambiente saudável. Em virtude disso, defende-se não só a criação de boas instituições e leis como também a sua aplicação de modo igualitário, equitativo, isonômico, impessoal. Isto, frise-se, demanda que a igualdade não exista somente do ponto de vista formal, mas que se adote uma perspectiva racialmente centrada para que seja possível que finalmente se assegure a igualdade material. Retomando o questionamento inicial do trabalho, é possível a leitura do racismo ambiental como fenômeno através do qual leis e políticas de proteção ambiental podem também ser capazes de afetar de modo desigual - intencionalmente ou não - grupos racialmente distintos.

A conclusão publicada pela National Law Journal expôs o caráter institucional do racismo ambiental. Ocorre que, a despeito dos constantes ataques aos casos de racismo e da edição de normas legislativas em resposta, bem como apesar de haver a penalização das infrações racialmente discriminatórias, a população negra permanecia em condição de inferioridade, recebendo menor proteção estatal. Isto porque

“[...] as próprias instituições normais para o funcionamento da sociedade americana estavam a provocar consequências que eram prejudiciais para os negros e representavam uma espécie de racismo institucional" (Rex, 1988, p. 170) ${ }^{41}$

Foi realizada em Washington a I Conferência Nacional de Lideranças Ambientalistas dos Povos de Cor $^{42}$, em 1991, que contou com a presença de líderes de diversos países ao redor do globo a fim de desenvolver estratégias e planos comuns de combate ao racimo ambiental. ${ }^{43}$

\footnotetext{
${ }^{41}$ Disso decorrem diversos obstáculos à análise do racismo ambiental - sobretudo no Brasil - já que a discriminação institucional é pouco aparente e sua demonstração normalmente impõe a análise de estatísticas racialmente específicas quanto ao órgão sob exame. O principal problema é que, no Brasil, tais dados são deveras escassos, sendo habitual que, em nome da impessoalidade e isonomia - e, curiosamente, produzindo resultados avessos às mesas - não se anota ou registra dados racialmente relevantes. Veja-se, por outro lado, que não se pode deixar de questionar ou buscar meios alternativos aptos a denotar a institucionalização da discriminação racial neste país em virtude da invisibilização de cor ser traço das metodologias e epistemologias dominantes.

${ }^{42}$ No original: First National People of Color Environmental Leadership Summit.

${ }^{43}$ Houve o processo de internacionalização do movimento, eis que países que compartilhavam semelhante processo de subjetivação racial experimentavam o mesmo problema, temperadas as
} 
De acordo com Bullard (2002), durante a conferência, oficialmente ampliou-se o leque de pautas do racismo ambiental para conferir especial relevo a questões de moradia, saúde pública e uso do solo, por exemplo. Ao final do evento aprovou-se os “17 Princípios da Justiça Ambiental”, consolidando o movimento de justiça ambiental como uma rede internacional de enfrentamento ao racismo ambiental. ${ }^{44}$

Em grande medida responsável pela difusão do movimento por justiça ambiental no cenário internacional, foi a publicação do documento que fora popularmente batizado de Memorando Summers. ${ }^{45}$ Conforme explica Rammê:

"No referido memorando, Lawrence Summers economista chefe do Banco Mundial à época, apontou três razões para que os países pobres fossem o destino dos polos industriais de maior impacto ao meio ambiente. A primeira delas: o meio ambiente seria uma preocupação "estética", típica dos países ricos; a segunda: os indivíduos mais pobres, na maioria das vezes, não vivem tempo suficiente para sofrer os efeitos da poluição ambiental; e a terceira: pela lógica econômica de mercado, as mortes em países pobres têm um custo mais baixo do que nos países ricos, pois seus moradores recebem menores salários" (RAMMÊ, 2012, p. 24)

O choque que o conteúdo das palavras de Summers provocou na comunidade internacional colaborou com o fortalecimento do movimento por justiça ambiental. Emergiu um novo debate acerca da proteção do meio ambiente, não mais exclusivamente dedicado à vertente ecológica mas também incorporando os demais aspectos ambientais fundamentais para a subsistência humana.

Questiona-se, ainda, a relação entre o modelo econômico de produção e práticas generalizadas de injustiça ambiental. Como bem aponta Acserald (2010), o movimento por justiça ambiental promoveu uma verdadeira "ressignificação da questão ambiental". Evidenciou-se, por fim,

particularidades internas. A conferência, portanto, buscava estratégias políticas de combate ao racismo ambiental não só nos Estados Unidos mas também em outros países.

${ }^{44}$ Através da Ordem Executiva 12.898/94, o então presidente dos Estados Unidos, Bill Clinton, não só determinou que todos - indistintamente - eram titulares do direito ao meio ambiente saudável, como obrigou que a Administração incorporasse as demandas por justiça ambiental.

${ }^{45}$ Destinado a circular somente entre funcionários do Banco Central, o memorando foi publicado pela The Economist em 8 de fevereiro de 1992. 
que práticas de racismo ambiental eram intencionalmente executadas não somente nos Estados Unidos, mas de maneira global. ${ }^{46}$

É certo que a existência de injustiças ambientais em diversos países, sobretudo os do continente americano, justifica-se por um processo comum de construção da subjetividade a partir da noção de "raça" que definiu as bases de organização da sociedade. Por outro lado, é também inegável que, num mundo globalizado, certamente a manutenção - e até fomento, como no caso do memorando supracitado - de práticas de racismo ambiental acarretaria impactos globais, a partir de uma configuração não equitativa de proteção dos diferentes povos. Não é outro o entendimento de PortoGonçalves que assevera que "[...] há uma geografia desigual dos proveitos e dos rejeitos conformando o sistema mundo moderno-colonial, o que coloca na ordem do dia o movimento por justiça ambiental" (Porto-Gonçalves, 2006, p. 388).

De acordo com Brulle e Pellow (2005), os arranjos internacionais frequentemente submetem países da América Latina, África e Ásia à desproporcional imposição de ônus ambientais, sobretudo pela dimensão política de decisões tomadas por países do hemisfério Norte - ou "de primeiro mundo". É que

“[...] a dimensão global alcançada pelo movimento por justiça ambiental introduziu uma crítica nova ao debate ambiental, direcionada ao processo de produção capitalista. No atual modelo neoliberal de desenvolvimento, há uma lógica econômica perversa, que ignora por completo a ideia de equidade na repartição das externalidades negativas do processo produtivo. Ainda, a crítica do movimento por justiça ambiental identifica as questões econômicas globais diretamente relacionadas com casos de injustiças ambientais em diversas partes do mundo, como, por exemplo, a ausência de uma efetiva regulação sobre os grandes agentes econômicos do risco ambiental, situação que possibilita a eles uma livre-procura por comunidades carentes, vítimas preferenciais de suas atividades geradoras de riscos ambientais. [...]

A internacionalização do movimento por justiça ambiental fez com que as demandas do movimentos passassem a abarcar as lutas e os protestos contrários à distribuição desigual dos

\footnotetext{
46 Como leciona Bullard, o “[...] clamor por justiça ambiental e econômica não termina nas fronteiras dos EUA, mas estende-se às comunidades e nações que são ameaçadas pela exportação de resíduos perigosos, produtos tóxicos e indústrias sujas” (Bullard, 2002, p. 59)
} 
perigos e riscos relacionados à poluição do ar e das águas; aos desastres ambientais; às mudanças climáticas; à insegurança alimentar; à degradação ambiental causada pelo setor industrial; aos modos de vida, tradições e cultura; ao acesso aos recursos naturais; sempre em abordagens vinculadas à desigualdade social e às práticas discriminatórias" (Rammê, 2012, p. 27)

$\mathrm{O}$ processo colonizatório, que primeiro integrou internacionalmente o mundo ocidental, produziu não só diferenciações raciais como uma série de efeitos gerais. Dentre esses, como bem assevera Bomfim (2005), há que se notar: o progressivo enfraquecimento da nação explorada; a imposição e instauração de uma série de processos violentos às nações parasitas; e a adaptação do colonizado às relações constituídas nos termos forjados pelo colonizador. Tais efeitos, defende, não só perduram na vigência do regime originalmente instaurado, mas naturalmente seguem influenciando a sociedade posteriormente, mesmo após a sua emancipação. ${ }^{47}$

É por essa razão que a supervisão do sistema democrático no Brasil e a análise da presença de racismo ambiental e da discriminação institucional demandam a utilização de lentes historicamente calibradas. Isto é, deve-se levar em consideração os impactos produzidos por processos políticos e sociais específicos, cujos efeitos se manifestam a médio e longo prazo. É o que se apresenta no segundo capítulo do presente trabalho, que trata das bases do racismo e, por conseguinte, dos males que fundamentam o racismo ambiental no Brasil.

\footnotetext{
${ }^{47}$ De acordo com o autor, "o regime parasitário sob o qual nasceram e viveram as colônias da América do Sul influiu naturalmente sobre o seu viver posterior, quando já emancipadas. Há no caráter das novas nacionalidades uma série de qualidades - vícios - que são o resultado imediato desse mesmo regime imposto pelas nações ibéricas. Essas qualidades traduzem a influência natural do parasita sobre o parasitado, influência constante, fatal mesmo, nos casos de parasitismo social, máxime quando o parasitado procede diretamente do parasita, quando é gerado e educado por ele" (BOMFIM, 2005, p. 135)
} 


\section{Capítulo 2: As relações raciais e o racismo no Brasil}

\subsection{O mito da democracia racial brasileira no cenário internacional: o Projeto Unesco}

O mito da democracia racial foi um discurso difundido e bem aceito no Brasil, tanto que colocou o país no cenário internacional como paradigma de inspiração em termos de relações raciais. Com efeito, foi amplamente divulgada e consolidada a imagem do país como plena democracia racial, auferida a partir de um bem sucedido processo de mestiçagem entre os povos fundadores. Assim, havia grande interesse em refletir a respeito da evolução das relações entre brancos e não-brancos no Brasil, a forma como teriam se transformado desde o período colonial até aquela época, pelo que houve, dos anos 40 a 50, exponencial crescimento de pesquisas relativas ao tema.

Em virtude disso, a Unesco - Organização das Nações Unidas para a Educação, Ciência e Cultura - promoveu a realização de uma série de estudos e pesquisas - o chamado "Projeto Unesco" com vistas a identificar os indicadores que proporcionaram o sucesso da experiência brasileira. Foi aprovada na quinta sessão da Conferência Geral da Unesco, em 1950, a realização de uma pesquisa sobre as relações raciais no Brasil (Maio, 1999). ${ }^{48}$

Como bem assevera Maio, o Projeto não só "gerou um amplo e diversificado quadro das relações raciais no Brasil" como "contribuiu para o surgimento de nova leituras acerca da sociedade brasileira em processo acelerado de modernização capitalista" (ibid., p. 142). Ademais, permitiu-se avaliar os termos em que vinham se consolidando determinados ramos do conhecimento, tais como a antropologia e a sociologia, as perspectivas com

\footnotetext{
${ }^{48}$ Dentre os estudos e pesquisas publicados, destaque-se os seguintes: WAGLEY, C. et al. Race and class in rural Brazil, publicado em 1953; NOGUEIRA, O. Relações raciais no município de Itapetininga. In: Relações raciais entre negros e brancos em São Paulo, e Preconceito racial de marca e preconceito racial de origem, ambos publicados no ano de 1955; e, por fim, BATISDE, R. e FERNANDES, F. Relações raciais entre negros e brancos, também publicado em 1955. Acerca da história do Projeto Unesco, pertinente ver MAIO, M. C. A história do Projeto Unesco: estudos raciais e ciências sociais no Brasil. Rio de Janeiro: Iuperj, 1997.
} 
que intelectuais brasileiros se debruçavam sobre o tema. A prioridade desses estudos foi estabelecida por Arthur Ramos ao assumir a direção do Departamento de Ciências Sociais da Unesco, segundo Maio (1999), ao lado de pesquisas que analisassem as problemáticas socioeconômicas sofridas.

Ramos, conquanto acreditasse na veracidade do mito da democracia racial, não deixou de observar e denunciar a existência do "preconceito de cor" e de profundas desigualdades raciais nas relações sociais brasileiras. O autor apontava a importância de estudos que buscassem analisar o período escravocrata e seus impactos na ordem social brasileira, não só para vislumbrar de um ponto de vista racial e objetivo as relações remanescentes como também com o fito de compreender as influências psicológicas que a noção de "raça" e as relações racialmente forjadas teriam provocado nos grupos dominantes, além da formação de "estereótipos de opiniões e atitudes" (ibid., p. 142-143).

O "programa da Antropologia brasileira", desenvolvido pelo diretor da organização intergovernamental, punha em evidência a importância de estudar no que mudanças culturais vultuosas, dentro de um contexto histórico, podiam resultar de forma sistemática, máxime sob o viés do grau de inserção de determinados grupos em classes sociais determinadas. Daí, vale dizer, seria possível começar a compreender a dinâmica da discriminação racial e as desigualdades que impõe.

Há que se pôr em evidência a relevância desse circuito de pesquisas naquele contexto: o mundo, ainda abalado com os horrores da Segunda Guerra Mundial, buscava respostas, diretrizes, mecanismos e estratégias para fomentar relações igualitárias e verdadeiramente democráticas entre os povos. Máxime em função das barbaridades realizadas na Alemanha nazista em nome da supremacia racial, as notícias acerca do patamar de igualdade brasileira despertaram especial interesse da Unesco. ${ }^{49}$

\footnotetext{
${ }^{49}$ De acordo com Hofbauer, "somente com o desmonte dos projetos políticos ideologicamente fundamentados em concepções raciais, depois da Segunda Guerra Mundial, que a comunidade acadêmica internacional fez um esforço para desqualificar o conceito de raça como critério único
} 
O Brasil se apresentava, então, como a consolidação dos valores políticos que o mundo buscava consagrar. A tese da democracia racial, no interior do país, se desenvolvia sobretudo como um esforço de fortalecer a identidade nacional. As pesquisas empreendidas visavam não somente compreender o estado das relações raciais no país como também avaliar estratégias de inclusão de certos segmentos sociais ao corpo social.

Foi criado o Setor de Relações Raciais do Departamento de Ciências Sociais da Unesco, dirigido por Alfred Métraux ${ }^{50}$, que, auxiliado por Ruy Coelho, conduziu e coordenou o Projeto Unesco. Inicialmente, as empreitadas se circunscreveriam tão-só ao Estado da Bahia, pelo que foram realizados diversos estudos sobre o negro na região, especialmente em função da remanescente forte presença da cultura africana (MAIO, 1999). Wagley, antropólogo norte-americano que já conduzia estudos raciais no Brasil, formou então um projeto com a Unesco: com vistas a desenvolver estratégias e políticas de modernização das áreas, seriam conduzidos estudos em três comunidades em Salvador. O objetivo era compreender as condições de vida e relações inter-raciais formuladas nos grandes centros urbanos brasileiros.

Por outro lado, Otto Klineberg chamava atenção às pluralidades inerentes a um país de dimensão continental. ${ }^{51} \mathrm{O}$ Rio de Janeiro, também por influência de Luiz Aguiar Costa Pinto, foi rapidamente posto sob os holofotes do Projeto Unesco, sobretudo por apresentar tensões raciais latentes ao tempo em passava por um processo de crescente urbanização e industrialização, embora o epicentro dos estudos permanecesse sendo experiência baiana.

de definição e explicação das diferenças humanas" (Hofbauer, 2006, p. 219). Foi desenvolvido o Projeto Unesco como esforço de elaborar uma campanha de combate ao ódio racial. O Brasil, que não só se apresentava como uma democracia racial mas também como um país que rechaçava o preconceito de cor, foi escolhido como laboratório de estudos.

50 Métraux assumiu a direção do Setor no ano de 1950, era antropólogo e já possuía vasta experiência em pesquisas etnológicas em relação a índios e negros na América Latina.

${ }^{51}$ De acordo com o autor, seria "[...] muito importante estudarem-se as relações raciais sob um certo número de condições distintas e, nesse caso, é imprescindível que, mais uma vez, o estudo não fique restrito à situação na Bahia e à sua volta" (Klineberg apud Maio, 1999, p. 144-145). 
À época, ganhavam fôlego empreendimentos de propagação dos discursos de igualdade racial. Acontecia na França, em 1950, o $1^{\circ}$ Congresso do Negro Brasileiro, que objetivava aproximar a elite intelectual e o movimento negro e tinha Abdias Nascimento como uma das suas principais lideranças (MAIO, 1999). Através dele, atraiu-se a atenção da Unesco para pesquisadores já interessados e engajados em pesquisas cuja temática eram as relações raciais desenvolvidas na América Latina. Além disso, os objetivos do TEN - Teatro Experimental do Negro -, que patrocinara o referido Congresso, eram compatíveis com os objetivos da organização intergovernamental.

Nascimento (1950) já alertava que, conquanto muito se divulgasse de forma positiva as condições das relações raciais no Brasil, restavam evidentes disparidades socioeconômicas racialmente discriminadas, não resolvidas com a mera extinção do regime escravocrata. Com efeito, é bem de ver que a abolição negligenciou necessidades fundamentais do povo negro, criando um contingente populacional expressivo que, em sua maioria, não tinha condições jurídicas de adquirir terras ou ascender socialmente. Sem qualquer amparo institucional, o povo negro se viu na ponta de políticas públicas que o buscavam extirpar, ao revés de integrar, do corpo social. O discurso que se estabeleceu, contudo, foi o de que no Brasil se vivia numa democracia racial.

Embora o Congresso tenha buscado oferecer uma linha de pesquisa alternativa à Unesco, não logrou êxito. O que se evidencia, contudo, é que, apesar de fortemente influenciador do pensamento intelectual, o Projeto Unesco enfrentou certa disputa, tanto em termos acadêmicos quanto políticos. Vale dizer, diversos dos acadêmicos contactados pela Unesco para integrar o projeto estavam presentes no Congresso ou mantinham relações com cientistas que lá apresentaram teses.

O resultado do embate, conforme resposta do diretor do Setor de Relações Raciais da Unesco, foi que, para além dos estudos promovidos pela entidade, houvesse um esforço no desenvolvimento de estratégias e 
políticas de efeito prático. Isto é, de um conjunto de ações que buscasse, a partir das reflexões teóricas, empregar técnicas que aplacassem as tensões raciais.

Para viabilizar os estudos, tomou-se como referência dados fornecidos pelo Instituto Brasileiro de Geografia e Estatística - IBGE - a respeito da composição racial da população brasileira. Digno de nota é fato de que existem críticas ao modo que o indicador "raça" é tomado pelo IBGE. É que, como se pode ver, a questão se conectava diretamente ao tema da miscigenação racial - cuja tese de harmonia se buscava reforçar. O mito da democracia racial se prestaria, para a elite intelectual, como um meio de incluir o Brasil ao rol de nações “civilizadas” (Anjos, 2013).

A imprecisão conferida ao indicador racial fortaleceria as crenças no mito da democracia racial e sofria ingerência do projeto de branqueamento que vinha sendo aplicado ao país:

“A própria Diretoria Geral de Estatística, em 1872, propunha o estabelecimento de uma política educacional como solução para esse problema (Camargo, 2010, p. 228; Loveman, 2009, p. 443). No entanto, o que se impõe a essas elites é a ideia de que o Brasil se civilizaria pelo "branqueamento de sua população" (Andrews, 1996, p. 485; Loveman, 2009). Essa concepção propunha que a população brasileira iria se tornando progressivamente branca pela mistura entre as raças, contribuindo para isso tanto o decréscimo "natural" da população negra - por conta de uma taxa de natalidade mais baixa, doenças e desorganização social, ou seja, pela ausência de políticas de mitigação das péssimas condições de vida de exescravos e seus descendentes - quanto a imigração de europeus ao Brasil (Camargo, 2010, p. 231-232; Loveman, 2009, p. 466; Skidmore, 1976, p. 81).

As estatísticas oficiais foram usadas para demonstrar esse processo. Muito embora o quesito racial nos censos tenha sido, em vários momentos, questionado por membros do IBGE a partir de argumentos técnicos - e justamente esse, da imprecisão das categorias raciais e da possibilidade de declarações "inverídicas" sobre a "raça" do informante -, nas publicações do Instituto "raça" é central para a imagem de nação brasileira, é parte do trabalho de "[...] não apenas descrever a realidade, mas de modelar o auto-entendimento nacional" (Loveman, 2009, p. 439). Assim, mesmo no Censo de 1920, no qual o quesito racial não foi pesquisado, em seu texto de introdução é assinalado que o Brasil atingiria a pureza étnica através da miscigenação e da imigração europeia [...]" (Anjos, 2013, p. 109-110). 
Ainda assim, impende notar que o Censo se mostra como um dos métodos objetivos, dentre escassos disponíveis, de aferição do caráter racial por localização geográfica, dentre outras categorias. ${ }^{52}$

É importante ressaltar, no mais, que os estudos do Projeto Unesco não tratavam da questão racial de forma autônoma, mas sempre incorporada a outras mazelas sociais. Havia a crença de que abolição da escravatura teria erradicado os males sofridos pelo povo negro no Brasil, o que poria em destaque trabalhos como os de Nina Rodrigues e Arthur Ramos até a primeira metade do século $\mathrm{XX} .{ }^{53} \mathrm{~A}$ visão do negro estabelecida por esses autores viria a ser mitigada a partir da notoriedade conferida aos esforços de autores como Gilberto Freyre, Caio Prado Jr. e Sergio Buarque de Holanda.

Com o aprofundamento dos olhares do Projeto sobre o Brasil, os coordenadores registraram a efetiva "carência de estudos sobre o padrão de relações raciais existente no Brasil" (Maio, 1999, p. 147). Outrossim, questionava-se a eficácia do emprego de determinadas técnicas e métodos para analisar o preconceito racial:

"É duvidoso, por exemplo, que o uso de questionários que lidem diretamente com atitudes raciais dê um retrato adequado da situação. Deve-se ter em mente que, no Brasil, considera-se uma vergonha o fato de se ter preconceito racial. Como resultado disso, tais preconceitos, quando realmente existem, podem assumir formas ocultas e sutis que não são reveladas pela técnica de questionários" (Métraux \& Coelho, 1950, p. 3)

Conquanto fosse amplamente aceita a tese de que o Brasil vivia uma democracia racial, já havia a percepção de que nessa sociedade se

\footnotetext{
${ }^{52}$ Note-se que "partindo de uma perspectiva de branqueamento, que termina por sustentar a realização gradual de valores paradigmáticos supremos (religioso-morais, biológico-evolutivos, cultural-civilizatórios), um "mais escuro" pode ser visto como um ser que - a longo prazo contribui para o aperfeiçoamento desse "projeto societal". Mas pode ser considerado também moral, biológica e culturalmente "inferior" àquele que consegue apresentar-se como "menos escuro". Assim, qualquer denominação de cor e/ou raça ganha uma forte carga de ambiguidade. Essa ambiguidade, que marca os processos de inclusão e exclusão e que pode ser interpretada como uma consequência da força do ideário do branqueamento, foi provavelmente também uma das razões porque o Brasil oficial conseguiu, com sucesso, apresentar-se durante tanto tempo como país não-racista" (Hofbauer, 2006, p. 213)

${ }^{53}$ Válido o apontamento de Hofbauer a respeito da alforria: "não provocava um rompimento com as estruturas de domínio; não era garantia de uma "vida em liberdade". O Brasil escravista não permitia a existência de um "cidadão livre". A sociedade era marcada por laços de dependência, de lealdades, de poder patrimonial. O liberto não constituía a antítese do escravo, mas apenas um possível - passo em direção à diminuição da exploração direta, um precondição para ocupar uma posição menos desprivilegiada no jogo de manipulação dos laços de pertencimento." (ibid., p. 150).
} 
experimentava formas peculiares de racismo: bastante sutis e por vezes veladas, porém não menos violentas. Por essa razão, velhos métodos de análise não se prestariam a detectar com eficiência as nuances das relações raciais brasileiras. Destaque-se que "os estudos deveriam levar em conta o padrão de vida de brancos e não-brancos, incluindo salários, tipos de ocupação e, de modo mais abrangente, a interferência da religião na dinâmica das relações raciais". (Maio, 1999, p. 148).

Foi somente no final do ano de 1950 que o coordenador do Projeto, após visita ao Brasil, reconheceu que não só eram necessárias pesquisas complementares em outros Estados que não a Bahia, como que existiam particularidades locais no trato socioracial. Assim, os principais estudos baianos focaram não só na vida dos negros que habitavam em comunidades rurais, como as condições de vida que detinham no centro urbano - na cidade de Salvador - e as suas possibilidades de ascensão social. As pesquisas promovidas no Rio de Janeiro e em São Paulo buscavam principalmente entender os efeitos da industrialização e do processo de urbanização nas comunidades negras e nas relações raciais. Essas cidades foram incluídas no Projeto com a finalidade de tornar mais completo o relatório final.

Posteriormente, a Bahia deixou de ser o epicentro das pesquisas promovidas pelo Projeto Unesco. ${ }^{54}$ No ano seguinte, o coordenador do Projeto incluiu, ainda, estudos sobre a cidade de Recife - PE. No mesmo ano, Freyre começou a se aproximar academicamente da empreitada da organização internacional. Assumiu, então, o cargo de Diretor do Departamento de Ciências Sociais da Unesco.

\footnotetext{
54 Maio relata a decisão que Métraux comunica por carta: "Contrariamente a meus planos anteriores, a Bahia não será mais o foco de nosso projeto. Estudaremos as relações raciais como estas aparecem em quatro comunidades e nos concentraremos no problema de mobilidade social na cidade de Salvador. Por outro lado, deveremos nos concentrar na situação racial em São Paulo, que está em vias de se deteriorar rapidamente. Dr. Costa Pinto empreenderá um estudo semelhante - porém em maior escala - no Rio de Janeiro. Espero conseguir, no final do ano, um quadro da situação racial no Brasil que seja próximo da realidade e que cubra, ao mesmo tempo, tanto seus aspectos positivos quanto os negativos" (Métraux apud Maio, 1999, p. 150).
} 
Ocorre que muito se afirma que, ao revés do objetivo inicial, que seria encontrar os indicadores que teriam viabilizado o estabelecimento e manutenção de relações raciais harmoniosas, a UNESCO teria encontrado dados concretos que certificavam a existência do forte racismo brasileiro. Um dos principais esforços teria sido esvaziar de sentido e validade da noção de raça, em virtude do traumático desfecho da recente guerra mundial. ${ }^{55}$

Contudo, o amplamente referendado mito da democracia racial e a fiel crença de muitos pesquisadores não foi capaz de invisibilizar a realidade das relações raciais. Embora visível o grau de resistência da cultura africana e a existência de muitos de seus traços impregnando a cultura brasileira, a identidade negra se mostrava seriamente prejudicada:

"No primeiro semestre de 1951, cinco meses após visitar o
Brasil, Alfred Métraux publicou um balanço de sua viagem na
revista Courier, da Unesco, sob o sugestivo título "Brasil: terra
de harmonia para todas as raças?" ("Brazil: land of harmony for
all races?"). Nele, o autor apresentou um painel contrastante do
cenário racial brasileiro (Métraux, 1951b, p. 3). De início,
Métraux tece alguns comentários históricos, antropológicos e
sociológicos sobre Salvador. Do seu ponto de vista, "a grande
'metrópole negra' brasileira" causava uma impressão paradoxal:
por um lado, era visível a forte presença da cultura africana; por
outro, o número de pessoas "realmente negras" era pequeno.
[...] A intensa miscigenação, segundo o antropólogo, gera
ausência de preocupação quanto à identidade racial. A seu ver,
são os problemas de natureza social que prevalecem." (Maio,
1999, p. 151). Note-se que a visão de Métraux fora influenciada pelos ensinos de Freyre, que, como se observa pelo que expõe em Casa Grande e Senzala, não eram de todo negativas. Buscando combater o preconceito de cor e a predominante visão, no país, do negro, do mestiço, do índio, do mulato, como inferiores e menos virtuosos, o autor exalta não só as características desses sujeitos como retrata a mestiçagem como um processo um tanto

\footnotetext{
${ }^{55}$ Azevedo, um dos pesquisadores do Projeto, rejeitava a premissa de que brancos e negros seriam grupos claramente delimitados. Apontando a existência de uma relação entre o status social e a cor, o autor "descreve o branqueamento como um fenômeno fundamentalmente social". Afirma, ainda, a possibilidade, no Brasil, do acesso a um determinado capital eminentemente branco como dinheiro, educação, "boas maneiras" e "boas relações pessoais" - permitiriam que um "mulato claro" ocupasse um lugar "socialmente branco", reconhecendo que isso não se aplicaria a negros de pele escura. Conclui que "para adquirir status, o escuro necessita assimilar-se cultural e socialmente ao branco adotando sua "epiderme social"” (Hofbauer, 2006, p. 266)
} 
menos violento do se tem registro. De fato, a nota de cordialidade da discriminação racial no Brasil é capaz de desnortear os indicadores comumente utilizados para identifica-la.

Ainda assim, Métraux percebe que havia um limite fenotípico no trato socioracial. $\mathrm{O}$ autor reconhece, ao analisar laços matrimoniais, que estes muito raramente aconteciam entre indivíduos em posição distante no espectro de cores de pele. Não passou despercebido, inclusive, a existência e perpetuação de uma série de estereótipos em relação ao negro, bem como a marca do fenótipo nas relações inter-raciais, sobretudo no Rio de Janeiro e em São Paulo. As razões identificadas remetem às relações coloniais. $\mathrm{O}$ diagnóstico do Projeto Unesco contemplou, finalmente, um misto das perspectivas positivas e otimistas a respeito da sociedade brasileira e os inegáveis traços do racismo que se manifestaram durante as pesquisas.

\subsection{Racismo ambiental e o racismo no Brasil: análise histórica}

Debater acerca do racismo ambiental no Brasil demanda incursões históricas: não se pode compreender os elementos desagregadores das relações raciais brasileiras sem estudar seus males de origem. É fundamental que se compreenda o forte impacto da invenção de uma nova concepção de "raça" e principalmente como essa noção foi incorporada e atualizada pelos mecanismos sociais que aqui se tem. Como visto, mesmo para cientistas sociais, antropólogos, sociólogos, com plena convicção na existência de harmonia entre brancos e não-brancos em solo brasileiro, as formas de violência próprias aqui mantidas têm claro resquício do período escravocrata e produzem segregação. É que o parâmetro comparativo daqueles cientistas, cumpre atentar, era o Holocausto.

De toda forma, há que se cuidadosamente analisar as técnicas de genocídio da população negra empreendidas no país e seus impactos no tecido social, já originariamente calcado em relações de desigualdade. Diga-se, de antemão, que a despeito da força das correntes que apostam no critério socioeconômico como determinante das discriminações sociais, 
adota-se aqui paradigma diverso. Ocorre que, como se verá, até mesmo os estratos socioeconômicos se organizaram a partir de indicadores raciais, o que não deve ser desconsiderado. À conta disso, o indicador racial afetará o trato social mesmo quando razoavelmente nivelado o patamar socioeconômico.

É somente a partir da segunda metade do século XX que a percepção da existência de uma relação entre a justiça ambiental e a justiça social começa a receber certa notoriedade no Brasil. Atualmente, a persecução da justiça social é amplamente consagrada. A questão se encontra presente em todo o texto constitucional que consagra o princípio da dignidade humana (art. $1^{\circ}$, inciso III, CRFB), a construção de uma sociedade igualitária (art. $5^{\circ}$, caput, CRFB), a erradicação da pobreza (art. $3^{\circ}$, inciso III, CRFB), a extinção de todas as formas de discriminação (art. $3^{\circ}$, inciso IV, CRFB), o direito ao meio ambiente equilibrado (art. 225, caput, CRFB), o valor social do trabalho (art. $1^{\circ}$, inciso IV, CRFB), etc. Conquanto seja necessário apontar que a discussão a respeito da injustiça ambiental chegue ao Brasil com claro aporte internacional, o presente trabalho busca analisá-la a partir de conjunturas e elementos particulares à sociedade brasileira.

Ademais, busca-se apontar - e se valer de - instrumentos aptos a conferir certa visibilidade às possíveis formas de racismo ambiental na nossa sociedade, sobretudo no campo da habitação e do direito à cidade. Entende-se ser possível, a partir do olhar sobre o passado, compreender a construção de pilares que sustentam a manutenção de uma série de tensões e injustiças raciais no contexto urbano, especialmente na cidade do Rio de Janeiro. A lente que se utiliza para analisar o presente se presta a visibilizar, ao menos em certa medida, alguns dos graus de discriminação sofridos pela população negra e seus efeitos, bem como expor as dificuldades que obstam maiores avanços em determinadas análises.

Uma das peculiaridades brasileiras é o vínculo do racismo com a desigualdade social, laço que não ocorre necessariamente com a alocação racista de ônus ambientais nos EUA. Por isso, é necessário, para aprofundar 
os estudos do racismo ambiental no Brasil, estudar os processos de desenvolvimento e relação entre o racismo e a pobreza no país, atentandose para o fato de que isto decorre de processos políticos e sociais específicos.

O Brasil, antes de ser um fim em si mesmo, teria sido meio, ao integrar o mercado colonial português. Considerando que processo capitalista opera por regime de desterritorialização - e mediante constante expansão cultural, do mercado, da indústria, das técnicas e da tecnologia, das cidades e edificações, por exemplo -, a divisão do trabalho, antes contida na lógica camponesa, sofreria um processo de internacionalização, do qual o Brasil fez parte. A mão de obra seria, em princípio, importada do continente africano, depois, da Europa e, por fim, o país desenvolveria uma divisão interna, na medida em que o sudeste brasileiro passou a absorver mão de obra produzida no nordeste.

Diferente de outras colônias do continente americano, a colonização lusitana teria caráter semicapitalista, eminentemente comercial, sendo o povoamento do país realizado principalmente para assegurar a manutenção do controle de pontos estratégicos, sobretudo portos, para o desenvolvimento do circuito comercial internacional a que pretendia a Metrópole. Para tanto, uma das técnicas utilizadas era a de assimilação do povo outro, em certa medida viabilizada pelo prévio contato dos portugueses com os mouros, que teriam ocupado o território antes das Grandes Navegações e, assim, influenciado aquela população (Freyre, 2013).

Uma vez assentada a colônia portuguesa, a lavoura estabelecida no Brasil seria crucial para o perfeito funcionamento do circuito comercial internacional português. O Brasil produziria mercadoria suficiente para a compra de escravos africanos, que seriam a mão de obra e motor da produção latifundiária na colônia, restando o excedente da venda da produção, com fins de exportação, pertencente a Portugal. O povomento, nesse momento, se daria em grande medida pelo estupro de escravas negras, 
que assentaria as bases da miscigenação brasileira e teria ainda um fim econômico em si: além da dominação, o de multiplicar o contingente de mão de obra, visto que os filhos das escravas pertenceriam ao senhor de direito.

Não se sustenta a tese de relação harmoniosa entre brancos e nãobrancos quando verificado o modo com o qual a política colonialista lidou com a reinvenção da noção de "raça". Com efeito, o processo de integração e mistura dos povos se deu mediante a incorporação dos elementos culturais que não se conseguia extirpar - como forma de dominação e apagamento da cultura original - e de subjugação dos povos não-brancos. $\mathrm{O}$ mecanismo utilizado para a subjugação era a introdução forçada daquelas pessoas na relação colonial, sob novo regramento social, econômico e religioso, despidas do sentido de comunidade e, por vezes, da relação que tinham com o próprio corpo, como única alternativa à morte.

É verdade que o intercâmbio aqui operado deu origem a um povo novo, uma nova unidade celular populacional com características diversas dos seus fundadores. A etnia que se produziu, porque fruto da junção de tão variados e diversos povos - não se esqueça, afinal, de que os povos africanos e indígenas afetados não se tratavam de uma massa homogênea -, formou tendências e manifestações culturais inéditas. Por outro lado, "essa unidade étnica básica não significa, porém, nenhuma uniformidade, mesmo porque atuaram sobre ela três forças diversificadoras" (Ribeiro, 2005, p. 21). ${ }^{56}$

Essa unidade cultural e étnica orientou, em certa medida, cientistas sociais a incorrer no erro de enxergar a existência de uma democracia racial no país, acreditando que todos, independente de raça, etnia ou cor, viveriam harmoniosamente, de forma igualitária e equitativa. Esse caráter - o grau de

\footnotetext{
${ }^{56}$ As forças diversificadoras a que alude o autor seriam: (1) a ecológica, responsável por fazer surgir condições ambientais muito distintas nesse país de dimensão continental, o que certamente influi - sem qualquer fatalismo - nas relações humanas forjadas em determinado espaço; (2) A econômica, porque cria "formas diferenciadas de produção, que conduziram a especializações funcionais e a seus correspondentes gêneros de vida"; e (3) A imigração, "que introduziu, nesse magma, novos contingentes humanos, principalmente europeus, árabes e japoneses" (Ribeiro, 2005, p. 21).
} 
mestiçagem - da sociedade brasileira não pode ser utilizado para maquiar as profundas disparidades, antagonismos e tensões existentes.

Como visto, as lições de Freyre (2013) em muito influenciaram não apenas a imagem do Brasil no cenário internacional, como o olhar com que a sociedade brasileira debruçava sobre sua própria etnografia. $\mathrm{O}$ autor ressalta a plasticidade do povo lusitano e o impacto de seu prévio contato com os mouros nas relações que aqui seriam constituídas.

Por outro lado, o mesmo autor adotou posição expressamente contrária ao racismo científico, o que certamente impactou a elite intelectual, considerando a força que aquele discurso havia atingido no país. Afirma:

"O depoimento dos antropólogos revela-nos no negro traços de capacidade mental em nada inferior à das outras raças: "considerável iniciativa pessoal, talento de organização, poder de imaginação, aptidão técnica e econômica", diz-nos o professor Boas. E outros traços superiores. O difícil é compararse o europeu com o negro, em termos ou sob condições iguais. [...] Quanto aos testes chamados de inteligência, muitos deles de resultados tão defavoráveis ao nero, sua técnica tem sofrido restrições sérias. Goldenweiser ridiculariza-os como método de medir qualidades de raça; deixam o negro pouco acima do macaco, escreve ele. "O ponto de vista estatístico", acrescenta, "o desejo de exprimir os fatos em números e curvas e uma louvável atitude, resultado do método crítico e objetivo: mas tem seus perigos. Quando alguém exprime qualquer bobagem em palavras não há dano nenhum; mas se a exprime em fórmulas matemáticas surge o perigo da roupagem matemática dissimular a bobagem." Também Kelsey critica os testes na sua pretensão de medirem qualidades de raça; e aponta neles grossos defeitos e irregularidades de técnica desfavoráveis ao negro.

Aliás, os resultados desses testes têm sido contraditórios; e não unânimes em fixarem a "inferioridade mental" do negro, como pretende Sorokin." (Freyre, 2013, p. 379-380).

É verdade que a escrita elogiosa poderia ter levado a crer, num contexto de desgastação das relações inter-raciais, haver no Brasil uma democracia racial, mas não há propriamnte, na obra, uma defesa do termo. A unidade auferida pelas exaltadas platicidade do português e qualidades do mestiço, como bem expõe Ribeiro,

"[...] resultou de um processo continuado e violento de unificação política, logrado mediante um esforço deliberado de supressão de toda identidade étnica discrepante e de repressão e 
opressão de toda tendência virtualmente separatista. Inclusive de movimentos sociais que aspiravam fundamentalmente edificar uma sociedade mais aberta e solidária. A luta pela unificação potencializa e reforça, nessas condições, a repressão social e classista, castigando como separatistas movimentos que eram meramente republicanos ou antioligárquicos." (Ribeiro, 2005, p. 23).

Um dos principais fundamentos que indicam a existência racismo ambiental no Brasil é justamente a perpetuação e modernização dessa relação de dominação, que se manifesta no binômio: repressão e opressão. As formas de opressão se manifestam, por exemplo, pelo desenho geográfico que aloca discriminatoriamente a população sob pretensa neutralidade; pelas formas sutis, naturalizadas, e altamente violentas de discriminação cotidianas; pela vedação de acesso ao espaço urbano pela desigual distribuição, injustificada, da alocação de políticas públicas e obras de mobilidade urbana.

A sociedade brasileira não evoluiu das suas antigas formas de sociabilidade, perpetuando relações originalmente escravocratas travestidas por máscaras de modernidade e civilidade. Esses recursos se prestam a afogar tensões reprimindo levantes, assim como outrora. O resultado, como aponta Ribeiro (2005), são um genocício e etnocídio implacáveis, o agravamento do distanciamento social e o acúmulo de tensões dissociativas de caráter traumático. 57

Com o processo de colonização dos continentes americano e africano houve a convergência de dois processos políticos específicos. Esses processos serviram não só como ponto inicial para a organização da sociedade americana como para o posicionamento dos países envolvidos em determinados assentos na sociedade internacional. Veja-se que a ótica do racismo ambiental se aplica ao Brasil não só no plano doméstico, mas

\footnotetext{
${ }^{57}$ Leia-se o seguinte excerto: "O povo-nação não surge no Brasil da evolução de formas anteriores de sociabilidade, em que grupos humanos se estruturam em classes opostas, mas se conjugam para atender às suas necessidades de sobrevivência e progresso. Surge, isto sim, da concentração de uma força de trabalho escrava, recrutada para servir a propósitos mercantis alheios a ela, através de processos tão violentos de ordenação e repressão que constituíram, de fato, um continuado genocídio e um etnocídio implacável. Nessas condições, exacerba-se o distanciamento social entre as classes dominantes e as subordinadas, e entre estas e as oprimidas, agravando as oposições para acumular, debaixo da uniformidade étnico-cultural e da unidade nacional tensões dissociativas de caráter traumático." (ibid., p. 23).
} 
também internacional, eis que o país ocupou historicamente espaços de subalternidade..$^{58}$

Um desses processos consistiu na codificação das diferenças entre colonizadores e colonizados, haja vista que os avanços tecnológicos da Era das Grandes Navegações permitiu novas relações com povos antes não alcançados - ou pelo menos a intensificação do contato com esses grupos. Ao lado disso, articulou-se uma distribuição do trabalho, envolvendo a transposição de mão de obra africana para as colônias americanas - o tráfico negreiro -, escravizada com base no desenvolvimento e resignificação do que se entendia por "raça". O conceito seria moldado com o objetivo de justificar uma suposta inferioridade natural de determinados indivíduos em relação a outros. Nesses termos se construiria a relação entre brancos e não-brancos.

Esses processos, como se pode perceber, retroalimentaram-se, viabilizando a formação de um circuito comercial internacional que se justificaria também por crenças racistas. Com efeito, a noção de "raça" se tornou parte integrante desse sitema de relações de poder, de controle do trabalho e dos corpos, influenciando um contingente numeroso de nações que conceberia o termo sob um processo de resiginificação que associaria à "raça" uma série de características fenotípicas e relativas à capacidade moral-intelectual do indivíduo. É que esse processo de resignificação funcionou justamente para traduzir as diferenças entre o fenótipo apresentado por colonizadores e colonizados.

À luz de uma epistemologia eurocentrada, que atribuia aos seus modelos de sociedade o título de máximo expoente de desenvolvimento e civilização, a noção de "raça" foi utilizada para justificar e forjar relações de dominação. Serviu, inclusive, como critério de posicionamento dos indivíduos em determinado lugar social, atividade laboral, nível hierárquico. Sobretudo na América Latina, a ideia de "raça" fora utilizada

\footnotetext{
${ }^{58}$ De modo que Ribeiro (2005, p. 20) afirma que o país se colocaria, no cenário internacional, como "proletariado externo".
} 
para legitimar as relações de dominação necessárias ao projeto de colonização pretendido (Quijano, 2005).

Há predominância do uso de mão de obra escrava até meados do século XIX, ganhando importância o uso do trabalhador imigrante europeu a partir de 1850, com o descréscimo do tráfico negreiro. A substituição da mão de obra escrava não buscou empregar o contingente de libertos disponibilizado com a abolição, mas investiu na imigração europeia como aposta de embranquecimento da população.

A consagração do racismo, segundo Theodoro (2008), dar-se-ia justamente no pós-abolição, com o fortalecimento do racismo científico e a difusão de suas premissas como matriz interpretativa do desenvolvimento nacional. Tais interpretações, que ganhariam substancial notoriedade da década de 1930, constituiriam a base de uma série de políticas públicas que contribuiriam para o agravamento das desigualdades na sociedade brasileira (Theodoro, 2008, p. 24)

A codificação das raças foi o pontapé inicial do que viria a constituir um aglomerado de estudos científicos e políticas públicas que se retroalimentariam e fundamentariam a discriminação racial, naturalizando o tratamento díspar a indivíduos pertencentes a grupos distintos em razão da sua raça, etnia ou cor de pele. A noção de raça, que antes correspondia à ascendência e família do sujeito, tornou-se uma referência conceitual para pensar diferenças humanas (Hofbauer, 2006), substituindo o critério religioso como elemento central organizador das sociedades ocidentais e, posteriormente, fortalecendo crenças de pureza racial.

Veja-se que

"Num primeiro momento, nobres protugueses e espanhóis recorriam ao termo raça (raza) para - de forma semelhante ao uso árabe-beduíno - destacar sua origem, sua descendência. Os princípios da história da noção de raça, portanto, nada têm a ver com uma diferenciação de grupos humanos segundo cores de peles diferentes ou outros critérios fenotípicos. [...] "Ser de boa raça", escreve Venturino (2003, p. 30; trad. do autor), "significa[va] pertencer a uma boa família, mas não a um grupo étnico ou racial no sentido moderno do termo. [Era] o conjunto das boas raças que [fazia] a nobreza". O mesmo autor enfatiza 
ainda que o ideário do "sangue puro" expressava em primeiro lugar, além das qualidades do "homem virtuoso", uma metáfora corporal de filiação e não, como posteriormente no séculos XIX, uma valorização de características biológicas." (Hofbauer, 2006, p. 100-101).

No entanto, é possível observar que o conceito começa a ser alargado já no séc. XVII, desconectando-se, com o passar do tempo, da característica genealógica e passando a servir como identificador de agrupamentos humanos. ${ }^{59}$ A raça - substituindo progressivamente aspectos religiosos e morais - se impunha como critério de exclusão ou inclusão de indivíduos, tomando como base suas características físicas (Hofbauer, 2006). Tais aspectos fenotípicos se atrelariam a características mais ou menos virtuosas para qualificar os seres humanos. ${ }^{60}$

Ao longo do respectivo século surgiriam tentativas de categorização dos seres humanos por diferentes cientistas e pensadores, tais como Carl Lineu, cuja sistematização biológica, que alinhava seres humanos e macacos, tornar-se-ia importantíssima referência em estudos do gênero. É na sua avaliação que a cor de pele dos indivíduos é cientificamente utilizada como fundamental na classificação dos diferentes grupos humanos, pelo que aproximava os povos africanos da bestialidade. ${ }^{61}$

O projeto de embranquecimento do Brasil assume importância na medida em que, com o avanço do racismo científico, ao tom de pele e à raça

\footnotetext{
${ }^{59}$ François Bernier, como aponta Hofbauer (2006), em 1684, aplicaria o conceito de raça para categorizar agrupamentos humanos com base em suas características físicas - ou fenotípicas - no artigo "Nouvelle division de la terre, par les différentes espèces ou races d'hommes"; o conceito de raça já seria expandido, em relação ao uso original, por Pierre Charron, em 1601, em "De la sagesse".

${ }^{60}$ Existem discussões a respeito da noção de "raça" como "dado biológico" ou "construção social". Embora, para autores como Wulf D. Hund exista um consenso no sentido de que o conceito se trataria de uma construção social, haveria ainda discussões sobre tal fenômeno consistir num "fato social" ou em "invenção", dentre outras controvérsias. Sobre o assunto, ver Hofbauer (2003).

${ }^{61}$ Ressalte-se: "Lineu subdivide o grupo homo em quatro categorias, juntando-lhe ainda dois grupos misteriosos (pouco definidos pelo autor), denominados ferus e monstrosus: (1) Europaeus albus: engenhoso, inventivo; branco, sanguíneo. É governado por leis. (2) Americanus rufus: contente com sua sorte, amante da liberdade; moreno, irascível. É governado pelos costumes. (3) Asiaticus luridus: orgulhoso, avaro; amarelado, melancólico. É governado pela opinião. (4) Afer niger: astuto, preguiçoso, negligente, negro, fleumático. É governado pela vontade arbitrária de seus senhores [...]" (Hofbauer, 2006, p. 104). Veja-se, ainda, que um dos mais importantes teóricos da raça, Gobineau, defendia que "a raça negra - chamada por ele também de hamitas e, menos frequentemente, de "variedade negra" - encontra-se no "degrau mais baixo da escada" da humanidade. Atribui aos negros que "nunca sairão do círculo mais estreito" um "caráter de animalidade" [...]" (ibid., p. 126).
} 
se condicionaram as possíveis virtudes e vícios de seres humanos. Criou-se um vínculo entre características fenotípicas e as de ordem intelectual e moral. Uma sociedade embranquecida corresponderia, então, a uma sociedade mais bela, evoluída, civilizada. Segundo Schwarcz, ganhava força o "evolucionismo social", que "concebia o desenvolvimento humano a partir de etapas fixas e pré-determinadas, e vinculava de maneira mecânica elementos culturais, tecnológicos e sociais" (Schwarcz, 1996, p. $83) .{ }^{62}$

A defesa da escravidão, por ter como um dos principais argumentos econômicos a questão da mão de obra, produziria impactos na organização do mercado de trabalho no pós-abolição, fortalecendo a divisão socioracial orientada pela cor de pele dos indivíduos. Com efeito, desenvolveram-se argumentos para ocultar as bases raciais e o preconceito de cor. Segundo Jaccoud:

“[...] se a elite colonial brasileira não organizou um sistema de discriminação legal ou uma ideologia racista que justificasse as posições sociais dos grupos raciais, ela compartilhava um conjunto de estereótipos negativos em relação ao negro que amparava sua visão hierárquica de sociedade. Nesse contexto, o elemento branco era dotado de uma positividade que se acentuava quanto mais próximo estivesse da cultura européia. [...]

Contudo, a abolição não significou o início da desconstrução dos valores associados às "designações de cor". Não apenas se observou a continuidade dos fenômenos de preconceito e da discriminação racial, como esses foram fortalecidos com a difusão das teses do chamado "racismo científico". A adoção, pela elite brasileira, de uma "ideologia racial" teve início nos anos 1870, tendo se tornado amplamente aceita entre as décadasde 1880 e 1920. A disseminação das teses racistas no Brasil e sua reconstrução na forma de uma ideologia racial ocorrem, assim, no período final da escravidão, quando estava em curso o processo de adaptação da sociedade à mudança do status jurídico dos negros" (Jaccoud, 2008, p. 47-48)

\footnotetext{
${ }^{62}$ A adoção de um projeto de branqueamento como política de Estado é noticiada nos debates da Assembleia Constituinte de 1823 , em que se debatia a concessão ou não do título de cidadão brasileiro a escravos forros, sendo-lhes imposto como condição o exercício de ofício ou cargo num contexto de ampla exclusão de negros do mercado de trabalho formal. As pretensões de incorporação de brancos e exclusão de negros se evidenciaria nas entrelinhas dos debates travados, que buscavam sempre alternativas que beneficiassem brancos e o embranquecimento da população (Rodrigues, J. H., 1974).
} 
Conforme afirma a autora, a abolição da escravidão no Brasil não foi capaz de aniquilar o preconceito de cor. As formas de discriminação inauguradas pelo regime escravocrata não só permaneceram como se fortaleceram com o desenvolvimento do racismo científico e das teorias raciais.

O racismo científico motivou a formulação de políticas que promovessem a submissão ou eliminação das "raças subalternas". Foram empregadas técnicas que buscavam intervir na reprodução humana, controlando o avanço populacional. A codificação racial serviu, inclusive, para justificar um tratamento institucional desigual entre brancos e nãobrancos. $^{63}$

Discussões e preocupações sanitárias, que atribuíam à mestiçagem e aos afrodescendentes um enfraquecimento biológico, o surgimento e a proliferação de doenças, fundamentaram intervenções autoritárias e políticas de segregação da população mestiça e negra (Schwarcz, 1996). A tese seria reforçada

"[...] pelos acadêmicos da faculdade de direito de São Paulo que buscavam impedir a entrada de imigrantes asiáticos e africanos. É nesse ambiente que os médicos cariocas passam a fazer elogios rasgados à política de imigração empregada na África do Sul [...]; fazem projetos de controle eugênico; ou dão apoio às leis de esterilização aplicadas em Nova Jersey [...]" (ibid., p. 95).

Outro exemplo se encontra nas lições de Nina Rodrigues (1957), que, em termos de política criminal, defendeu o tratamento desigual entre brancos e negros. Para o autor, a legislação penal deveria distinguir os criminosos de acordo com seu "desenvolvimento racial", eis que "raças

\footnotetext{
63 "Com efeito, desde os anos 1870, teorias raciais passam a ser largamente adotadas no país sobretudo nas instituições de pesquisa e de ensino brasileiras predominantes na época [...]. Já em maio de 1888, saía em vários jornais brasileiros um artigo polêmico, assinado por Nina Rodrigues, onde o famoso médico da escola baiana concluía que "os homens não nascem iguais. Suppõe-se uma igualdade jurídica entre as raças, sem a qual não existiria o Direito". Dessa maneira, e solapando o discurso da lei, esse "homem de sciencia", logo após a abolição formal da escravidão, passava a desconhecer a igualdade, e o próprio livre arbítrio, em nome de um determinismo científico e racial." (Schwarcz, 1996, p. 87-88)
} 
inferiores" naturalmente apresentariam menor aptidão ao respeito às leis (Hofbauer, 2006). ${ }^{64}$

Esse ideário municiaria a execução de um projeto de embranquecimento da população negra brasileira. Seriam elaborados esquemas de "cruzamento" interracial que calculariam a quantidade de gerações necessárias para extirpar a negritude do sujeito. Acreditava-se que os mestiços apresentariam maior aptidão intelectual em relação aos negros, o que motivara a elaboração de políticas "evolutivas" a partir de projetos de genocídio da população negra através do embranquecimento e do empobrecimento. Isto fora viabilizado pela institucionalização de mecanismos e técnicas destinados a concretizar o referido discurso.

Como bem explica Jaccoud,

"o ideal do branqueamento consolida-se nas décadas de 1920 e 1930, mesmo com o progressivo enfraquecimento das "teorias deterministas da raça". As elites nacionais percebiam a questão racial de forma cada vez mais positiva: para eles, o Brasil parecia branquear-se de maneira significativa, e o problema racial se encaminhava para uma solução. É o que apontam, por exemplo, os debates parlamentares que acompanharam a apresentação, ainda na década de 1920 , de projetos de lei, na Câmara dos Deputados, visando impedir a imigração de "indivíduos da cor preta". Seus opositores reuniam não apenas os que identificaram um teor racista nesses projetos, mas também aqueles que os consideravam inócuos, pois a trajetória recente já assegurava que o negro estava fadado ao desaparecimento no país em algumas décadas. Esse mesmo discurso é encontrado, ainda, nos debates da Assembleia Constituinte de 1934." (Jaccoud, 2008, p. 50)

O projeto de branqueamento serviria como "[...] suporte ideológico de relações de poder de tipo patrimonial que aqui se estabeleceram e se firmaram desde a Colônia" (Hofbauer, 2003, p. 68). É importante ressaltar que receberiam maior proeminência teses de autores que, embora

\footnotetext{
${ }^{64}$ Houve quem se insurgisse contra as ideias pregadas pelo racismo científico, mas essas vozes não receberiam grande notoriedade. Bomfim já em 1905 definia as relações forjadas pelos colonizadores como parasitária de povos africanos e nativo-americanos (ou ameríndios). O autor criticava a Teoria Científica do Valor das Raças, hegemônica na sociologia oficial europeia e estadunidense. Afirmava não só a igualdade racial como a aptidão de negros para o progresso premissa que era amplamente rechaçada por intelectuais e cientistas da época. Defendia-se que a mestiçagem sul-americana formaria populações inferiores e que o efeito desse cruzamento interracial seria a regressão moral e intelectual. Bomfim, já àquela época, rebatia sob o argumento de que a mistura de raças viabilizaria a duração e civilização dos povos, sendo a sociedade mestiça, em relação a muitos dos seus elementos de origem, superior.
} 
postulassem o extermínio da "raça inferior", rejeitavam conceitualmente a existência de limites rígidos entre brancos e não-brancos. ${ }^{65}$ Estes não seriam qualificados como racistas, mas seriam apoiados por toda uma elite intelectual que, apesar de seguir futuramente apoiando e naturalizando práticas racistas, consagrariam o "preconceito de ter preconceito" e afirmariam o mito da democracia racial. Além disso, "a crença na possibilidade de uma metamorfose da cor de pele (raça) ofereceu um suporte ideológico para a continuidade do exercício do poder patrimonialescravista" (id., 2006, p. 212).

Se por um lado destacava-se os "perigos da miscigenação e a impossibilidade da cidadania universal" (Schwarcz, 1996, p. 87), por outro, havia claro intento em marcar a representação do Brasil pela mistura de elementos que o tornavam um povo novo. Assim, se num momento se evidenciava a composição racial peculiar do brasileiro, noutro ocultava-se as raízes de influências de matriz africana e indígena, absorvidas pelo embranquecimento.

Tais teorias pregavam que uma célula populacional miscigenada, como a que aqui havia, estaria fadada ao fracasso, ofuscando importantes debates acerca da construção da cidadania. Empregou-se esforços concretos em técnicas de "evolução social" - branqueamento - ao revés de políticas públicas de distribuição de terra e inclusão do amplo contingente de libertos no mercado de trabalho e no corpo social.

Uma vez consolidada a teoria racial que justificaria uma suposta natural inferioridade de negros em relação aos brancos, foram fomentadas políticas de branqueamento no Brasil. No séc. XIX, as teses de "branqueamento rumo ao progresso" tinham maior força em relação ao

\footnotetext{
${ }^{65}$ Exemplifica-se pelo seguinte apontamento: "É curioso constatar também que a obra de um autor como Nina Rodrigues - que, baseado em concepções raciais essencialistas e, consequentemente, emprenhado na formalização das diferenças humanas, exigia medidas rígidas tanto de exclusão (a tentativa de elaborar graus de "responsabilidade penal", por exemplo) como de inclusão (por exemplo, a defesa do candomblé como uma confissão religiosa cuja prática era garantida pela Constituição) - tem sido, frequentemente, qualificada de "racista". Em contrapartida, o pensamento de Lacerda - que rejeitava a ideia de limites rígidos entre as raças e postulava, no fundo, o extermínio da "raça atrasada" para o "bem" da nação, num período de três a quatro gerações - tem sido, geralmente, poupado dessa acusação.” (Hofbauer, 2006, p. 212).
} 
período colonial, posto que encontravam maior grau de naturalização na população. Passaram a compor, então, políticas e práticas governamentais.

O projeto de embranquecimento teria consistido numa política de fomento à entrada de brancos europeus no país, sobretudo os que habitavam o norte da Europa, somada a imposição de barreiras à imigração de asiáticos e africanos e carência de políticas de inclusão social da população negra. Foram trazidos mais de 3,5 milhões de imigrantes, principalmente italianos, portugueses, espanhóis e alemães, durante quarenta e nove anos - de 1871 à 1920. ${ }^{66}$ Estimava-se que negros e mestiços corresponderiam a somente $3 \%$ da população no ano de $2012 .^{67}$

É a partir da década de 1930 que se inicia o esforço em abandonar o critério "raça" como categorizador das diferenças humanas e norteador de políticas de Estado, sobretudo em razão dos impactos da Segunda Guerra Mundial. Afirma-se a igualdade jurídico-formal dos seres humanos. O relatório do Projeto Unesco foi um trabalho significativo neste ponto, impulsionando discussões sobre a distinção entre raça e cultura, a inexistência de efetiva distinção racial entre os seres humanos e os fundamentos científicos do preconceito racial. A exemplificar os impactos e influência do Projeto na comunidade científica, destaca-se o avanço de geneticistas que lograram demonstrar a incompatibilidade entre as teorias raciais e a concepção biológica de raça. ${ }^{68}$

No Brasil, é principalmente a partir dos anos 1950 que o discurso até então hegemônico - do branqueamento passou a sofrer severos

\footnotetext{
${ }^{66}$ Já no Estado Novo, de acordo com Hofbauer (2006), haveria o reforço ao estímulo de imigração europeia com um Decreto-Lei de1945.

67 "Para essa estimativa, Roquette-Pinto recorreu aos censos de 1872 e 1890, que demonstravam uma redução gradual dos negros $(16,5 \% ; 12 \%)$ e mestiços $(38,4 \% ; 32 \%)$. Os números apresentados pelos censos refletiram certamente as baixas da guerra do Paraguai, das más condições de vida dos não-brancos e da chegada dos primeiros imigrantes europeus. Além disso, é difícil avaliar até que ponto a "ideologia do branqueamento" pode ter contribuído para "branquear" os dados. [...] Franco e Sequeira - apoiados em análises e propostas quase idênticas - tinham projetado o fim da raça negra igualmente num período de cem anos" (ibid., p. 211)

${ }^{68}$ No pós-guerra, intensificaram-se pesquisas no campo da diversidade racial entre seres humanos, comprovando-se que "[...] o conceito "raça", mesmo quando usado como uma categoria estritamente genética, não corresponde a nenhuma "realidade" observável no mundo da empiria (cf. tb. Santos e Maio, 2004). Cientistas como Templeton, Cavalli-Sforza e Jacquard demonstrariam que qualquer classificação dos seres humanos baseada em critérios genéticos é, no fundo, arbitrária" (ibid., p. 231).
} 
questionamentos (Hofbauer, 2006). A invalidação da noção de "raça" para referenciar distinções entre grupamentos humanos faz emergir as concepções de cultura, etnia e identidade. Os efeitos do racismo científico, porém, seguiram sendo produzidos, ante a naturalização e institucionalização de seus ideais.

É da relação entre o histórico negligenciamento do povo negro e sua imposição a condições de pobreza que surgem alguns dos problemas no debate da questão racial no Brasil. Vale ressaltar que

\begin{abstract}
"A pobreza não é um fenômeno inscrito na naturez das coisas, mas sim um produto de processos sociais precisos de despossessão (da terra, dos instrumentos de trabalho, de capital cultural, enfim, dos meios que permitam a reprodução das condições de existência), disciplinamento (dos corpos e das mentalidades) e exploração (da força de trabalho) para produção de bens e riquezas que são apropriados por outrem. Esse esquema, grosso modo, é um dos motores centrais da produção da desigualdade social e, consequentemente, da pobreza, seu efeito mais visível. Assim, a pobreza não é um estado, mas um efeito, fruto de um processo social determinado e com características próprias" (Acserald, 2009, p. 76)
\end{abstract}

A análise da problemática relativa ao racismo ambiental no Brasil apresenta complexidades em relação aos estudos norte-americanos. Não apenas a profunda desigualdade social mascara a desigualdade ambiental, a herança patrimonialista arraigada nas instituições e na sociedade cria obstáculos à separação entre espaço público e privado e referentes à temática do bem comum (Holanda, 1995).

De fato, o desprezo pelo espaço público se confunde com o desprezo por pessoas e comunidades, criando espaços privilegiados e restringindo o seu acesso. Há o enobrecimento de uma determinada região da cidade, "marcado pela valorização imobiliária, atração da população residente e usuária de maior renda e expulsão da população e atividades de baixa renda" (Rolnik, 1989, p. 51). Com isso, configura-se "uma situação constante de injustiça socioambiental no Brasil, que vai além da problemática de localização de depósitos de rejeitos químicos e de incineradores da experiência norte-americana" (Herculano, 2008, p. 5-6). 


\subsection{Segregação espacial socioracial no contexto urbano}

A aparente cordialidade do racismo brasileiro lança o desafio do estudo das suas especificidades. Por essa razão, a análise do racismo ambiental como obstáculo à concretização do direito à cidade impôs digressões históricas ao longo do trabalho. É fundamental, para a lúcida leitura do problema, que se tenha em mente o panorama já apresentado.

Não é razoável, ao analisar o problema da segregação espacial e dos diferentes graus de exposição a males ambientais, concebê-los como um dado natural. Isto é, como se essa organização territorial e a concomitante imposição de ônus desproporcionais resultassem de um processo espontaneamente regido pela natureza. Não se trata aqui do acaso, mas do resultado de processos políticos bem definidos - como a colonização e consecutivas práticas racialmente discriminatórias -, que produziram divisões sociais reproduzidas em relações estabelecidas em menor escala, capilarizando-as. Segundo Acserald, Mello e Bezerra, "esses efeitos desiguais ocorrem através de múltiplos processos privados de decisão de programas governamentais e de ações regulatórias e de agências públicas" (Acserald et al, 2009, p. 73).

É imperativo notar o papel do Estado na formação - e no agravamento - da segregação socioracial, que se manifesta por decisões governamentais, políticas públicas (por vezes insuficientes ou discriminatórias). Com efeito,

\footnotetext{
“As demandas mais específicas por direitos iguais à 'proteção ambiental' sugerem que qualquer distribuição desigual dos danos decorre da ausência concreta de políticas, a saber, da inexistência de um conjunto de medidas capazes de impedir que os agentes dotados de maior poder projetem sobre os destituídos a maior parte dos males ambientais do desenvolvimento" (ibid., p. 79)

É bem de ver que para que determinado ato configure racismo
} ambiental prescinde-se da existência de dolo ou culpa, não se exige que o ato seja necessariamente intencional, bastando que se verifique se foram 
produzidos resultados racistas. ${ }^{69} \mathrm{Ou}$ seja, não se avalia a intenção do agente, mas o resultado produzido pelo ato. É que um sistema regulatório que favorece o racismo ambiental se vale da institucionalização da discriminação a fim de manter maior oferta de bens e serviços em localidades determinadas, sobrepondo a populações de minorias étnicas piores condições de vida.

Considerando que a divisão colonial e internacional de trabalho produziu relações de poder calcadas em teorias raciais e que foram aproveitadas, em certa medida, pelo Estado Moderno, o corpo negro seguiu confinado a determinados lugares, socialmente e economicamente distribuídos, de inferioridade. De acordo com Rolnik (1989), a despeito das políticas de embranquecimento introduzidas no Brasil, haveria o confinamento de negros a determinados espaços. O trabalho da autora refuta a tese de que pobres brancos e negros partilhariam da mesma forma os mesmos espaços, atribuindo maior relevo ao fator racial.

A autora remonta o confinamento do corpo negro a determinados espaços ao período colonial. Em princípio, a senzala seria o espaço que ilustraria a submissão e a brutalidade dos senhores de engenho, impondo o totalitarismo empregado na divisão do trabalho. A disposição espacial e arquitetônica do modelo de produção soberanamente adotado no Brasil à época, bem como as regras de hierarquia social do período colonial, introduziriam "a diferença social em um contexto urbano pouco segregado" (Rolnik, 1989, p. 37). Existiriam, inicialmente, até mesmo quilombos urbanos.

Uma vez consolidada a teoria racial que "justificaria" uma suposta natural inferioridade de negros em relação a brancos, foram fomentadas políticas de branqueamento no Brasil. O Rio de Janeiro, em particular, embora também tenha sido alvo dessas políticas, de acordo com Rolnik (1989), seguiria sendo a área de maior concentração da população negra no

\footnotetext{
69 "O racismo ambiental não se configura apenas por meio de ações que tenham uma intenção racista, mas igualmente por meio de ações que tenham impacto racial, não obstante a intenção que lhes tenha dado origem" (Herculano, 2008, p. 16).
} 
Sudeste, em razão da menor entrada de imigrantes europeus e de uma intensa migração de libertos da zona rural fluminense para a urbana. Este fato teria provocado maior intervenção nos territórios negros no Rio de Janeiro quando, posteriormente, o governo municipal teria promovido uma reorganização territorial da cidade. ${ }^{70}$ Segundo Rolnik,

"A face urbana desse processo é uma espécie de projeto de 'limpeza' da cidade, baseado na construção de um modelo urbanístico e de sua imposição através de um poder municipal recém-criado. Um dos principais alvos de intervenção foram, nas duas cidades, justamente os territórios negros. [...] Em São Paulo, desde logo se configurou um padrão de segregação urbana marcado por uma espécie de zoneamento social: os ricos abandonaram a contiguidade dos sobrados do Centro da cidade para desenhar um espaço de privacidade e exclusividade burguesas" (ibid., p. 41)

As mencionadas políticas não só resultariam na reserva de determinados nichos de trabalho a pessoas brancas como promoveriam uma substituição da mão de obra negra em funções urbanas, confinando negros e pardos sobretudo ao trabalho doméstico. ${ }^{71}$ É nesse contexto de implementação de políticas de segregação racial e embranquecimento da população afro-brasileira que se constrói a marginalidade do negro e de seus territórios. ${ }^{72}$

\footnotetext{
${ }^{70}$ Em São Paulo, a população negra seria desalojada como etapa de concretização de um projeto urbanístico que demandava obras de "melhoramento da capital", as quais redefiniriam a face da cidade o acesso ao espaço público. Tratou-se de um "processo de limpeza" do Centro que, segundo Rolnik, consolidaria o Bexiga como território negro em São Paulo. As obras teriam seu ápice no período de 1899 a 1914. Já no Rio de Janeiro, o processo, "drástico e violento", ficaria conhecido como a "era do bota-abaixo". Iniciadas em 1904, as obras demoliriam os mais importantes quilombos da cidade - como enumera Rolnik: "a região portuária da Saúde e Gamboa e os cortiços e habitações coletivas da Cidade Nova (Sacramento, Santa Rita, Santana e Santo Antônio) (1989, p. 43) - afetando, inclusive, as relações de trabalho, na medida que houve o estreitamento de oportunidades de trabalho para a população negra com a reorganização espacial. No Rio de Janeiro, ademais, haveria justificativas sanitárias para o uso de medidas autoritárias, em grande medida fortalecidas pelo racismo científico que se consolidara dentre a elite intelectual.

${ }^{71}$ Dados do Recenseamento Geral da República dos Estados Unidos do Brasil, datados de 31 de dezembro de 1890, apontam que, naquele ano, $48 \%$ dos não-brancos inseridos no mercado de trabalho exerciam o trabalho doméstico e $16 \%$ não possuíam ofício. Além disso, os bairros proletários seriam habitados majoritariamente por imigrantes brancos, apresentando porcentagem de pretos e pardos sensivelmente inferior à média da cidade. Anote-se que foram levantados dados dos seguintes bairros: Sé, Santa Efigênia, Consolação, Bráz, Frequesia do Ó e Penha. (Rolnik, 1989).

${ }^{72}$ Veja-se o exemplo do Código de Posturas do Município de São Paulo, de 6 de outubro de 1886 (Arquivo Histórico Washington Luís): o diploma efetuou a proibição de práticas típicas de territórios negros. As quituteiras foram proibidas de vender seus quitutes, os mercados populares deveriam ser transferidos e os pais de santo não mais poderiam trabalhar.
} 
Rolnik (1989) destaca como territórios negros específicos dentro do contexto urbano: antigos quilombos urbanos, que remeteriam, no imaginário popular, à ideia de desorganização; ${ }^{73} \mathrm{e}$ os cortiços, que também tinham o caráter de marginalidade ante a sua inadequação aos parâmetros burgueses de habitação. Consigna também os terreiros como territórios eminentemente negros, ante o caráter de marginalização das religiões de matrizes africanas, à época, que ainda atualmente precisam combater fortemente o preconceito religioso, cuja raiz relaciona-se também com a demonização das suas práticas religiosas como forma de dominação. Há, finalmente, que se incluir as escolas de samba nesse conjunto de territórios bem definido.

Observa-se a importância do papel desempenhado pelo Estado na relação de subjugação racial por interesses econômicos. Esse processo se conjuga aos já mencionados na produção da segregação espacial socioracial. A partir de processos urbanísticos de redefinição do espaço, efetivamente se projetaria e concretizaria um modelo de cidade desigual, cujas premissas têm origem racialmente discriminatória.

Na definição de Marcuse, segregação "é o processo pelo qual um grupo populacional é forçado, involuntariamente, a se aglomerar em uma área definida, em um gueto" (Marcuse, 2004, p. 24). Com efeito, por intermédio da segregação sócio-espacial é possível que grupos dominantes controlem e produzam o espaço urbano, fazendo com que, organizado conforme seus interesses, o espaço afete o tecido social. ${ }^{74}$ Vale dizer, o espaço não deixa de ser um aspecto que integra o social, pelo que é capaz de sobre ele produzir efeitos.

\footnotetext{
${ }^{73}$ A autora explica que os quilombos urbanos eram identificados, ainda, pela não proletarização de sua população. Destaca, ainda, o corpo do negro como espaço seu, em virtude da sua importância cultural, manifestada na linguagem corporal contrária ao padrão moral judaico-cristão. (Rolnik, 1989, p. 42)

74 “Segregação, quer dizer, diferenciação residencial segundo grupos, significa diferencial de renda real - proximidades às facilidades da vida urbana como água, esgoto, áreas verdes, melhores serviços educacionais, e ausência de proximidade aos custos da cidade como crime, serviços educacionais inferiores, ausência de infraestrutura, etc. Se já existe diferença de renda monetária, a localização residencial implica em diferença maior ainda no que diz respeito à renda real" (Negri, 2008, p. 138)
} 
Para Negri (2008),

"Cada vez mais a cidade é lugar de atuação dos agentes de produção do espaço. Uma vez humanizados, esses espaços refletirão na sua arquitetura e na sua organização o padrão de desenvolvimento da complexidade das relações sociais. Este padrão ocorre por meio da segregação sócio-espacial, também denominada de segregação residencial da sociedade, principalmente por meio da diferenciação econômica. [...] A partir da Revolução Industrial, a maioria dos tipos de segregação encontrados no espaço urbano ocidental são por classe ou por etnia" (Negri, 2008, p. 130-131)

Rolnik (1989) destaca pelo menos dois processos estatais que viriam a definir a ocupação residencial da população negra. O primeiro deles diz respeito a operações urbanas administrativas na cidade de São Paulo que desalojariam a população negra do centro da cidade em função da incompatibilidade com o projeto urbano europeizado que se buscava implantar. O segundo diz respeito a obras executadas na cidade do Rio de Janeiro que provocariam intensa revolta na população negra e na sua consequente expulsão para os morros, hoje chamados "favelas" ou "comunidades", que se tornariam territórios eminentemente negros, ainda que não o sejam exclusivamente.

Veja-se que

"Se no Rio de Janeiro a luta pela apropriação do solo urbano acabou por consolidar as favelas como os espaços mais caracterizadamente negros da cidade é porque para ali afluiu uma mistura peculiar de histórias, um caminho singular que passou pela África, pela experiência da senzala e pelo deslocamento e marginalização operados pela abolição e a República. Da mesma forma, embora a população negra de São Paulo fosse menor do que a do Rio na década de 20, na Barra Funda, Bexiga, Liberdade, além de certos pontos da Sé, não só moravam negros como se configuraram territórios negros importantes, com suas escolas de samba, terreiros, times de futebol e salões de baile. Ainda nas primeiras décadas século, nas duas cidades, organizaram-se também sociedades negras, com atividades culturais e recreativas que envolviam a publicação de jornais, a produção literomusical e teatral, passeios, piqueniques e bailes de fim de semana em salões alugados. Em São Paulo, no Rio, os chamados 'Salões de Raça', situados no Centro da cidade, eram a opção de lazer da 'elite negra' (funcionários públicos, comerciários, contadores e técnicos). Os locais apontados até aqui como territórios negros jamais foram exclusivamente negros: desde os tempos da escravidão misturavam os pobres da cidade" (Rolnik, 1989, p. 44-45). 
Em São Paulo, a população negra seria desalojada como etapa de concretização de um projeto urbanístico que demandava obras de "melhoramento da capital", as quais redefiniriam a face da cidade o acesso ao espaço público. Tratou-se de um "processo de limpeza" do Centro que, segundo Rolnik (1989), consolidaria o Bexiga como território negro em São Paulo. As obras teriam seu ápice no período de 1899 a 1914.

Já no Rio de Janeiro, o processo, "drástico e violento", ficaria conhecido como a "era do bota-abaixo". Iniciadas em 1904, as obras demoliriam os mais importantes quilombos da cidade - como enumera Rolnik: "a região portuária da Saúde e Gamboa e os cortiços e habitações coletivas da Cidade Nova (Sacramento, Santa Rita, Santana e Santo Antônio)" (Rolnik, 1989, p. 43) - afetando, inclusive, as relações de trabalho, na medida que houve o estreitamento de oportunidades de trabalho para a população negra com a reorganização espacial. No Rio de Janeiro, ademais, haveria justificativas sanitárias para o uso de medidas autoritárias, em grande medida fortalecidas pelo racismo científico que se consolidara dentre a elite intelectual. As medidas geraram crises habitacionais e uma série de revoltas e depredações, resultando, ao final, na ocupação dos morros e expansão adjunta à linha férrea. ${ }^{75}$

Para Vargas (2005),

“A exclusão geográfica, tão bem expressa na manutenção, demonização e contínua desumanização das favelas, funciona como uma metáfora e como a corporificação concreta irrefutável de um sem-número de outros tipos de marginalização às quais as/os negras/os estão submetidas/os no Brasil - nas áreas de moradia, emprego, saúde, educação e representação política. É apenas confrontando a natureza multifacetada do racismo antinegra/o que seremos capazes de compreender (e contribuir para a eliminação de) as desigualdades raciais óbvias que caracterizam as relações sociais brasileiras." (Vargas, 2005, p. 80).

\footnotetext{
${ }^{75}$ É bem de ver que "As reformas realizadas no final do século XIX e início do século XX lançaram modelos estéticos e paisagísticos de embelezamentos das cidades e de ocultamento da pobreza. Para isso, ocorreu a regulação da atuação de alguns instrumentos urbanísticos, como a legalização de atuação do mercado imobiliário, implantação de projetos de saneamento ambiental e paisagismo, enquanto a população de baixa renda era expulsa para as áreas mais afastadas da cidade. Era a conjugação do modelo de embelezamento das cidades e segregação sócio-espacial das camadas mais pobres da sociedade" (Negri, 2008, p. 146).
} 
Um dos pilares do desenvolvimento econômico do Brasil seria a divisão racial do trabalho, em virtude de práticas de discriminação racial, já que determinadas funções seriam historicamente majoritariamente reservadas a pessoas negras, especialmente descendentes de escravos. Holanda (1995) defende que, ante o caráter lusitano de valorização de conquistas pessoais e aversão ao trabalho braçal, era comum que determinado indivíduo e sua descendência ficasse marcado negativamente pelo exercício de determinado labor.

Entretanto, acredita-se que, historicamente, não seria determinante a atividade laboral para tal discriminação, mas o elemento racial. Isto porque, mesmo após a Lei Áurea, dados os paradigmas sociais da época, considerando que os escravos foram libertos ao passo que, entretanto, nenhuma política pública houve que os integrasse ao mercado de trabalho ou fornecesse capacitação profissional para que viessem a exercer funções diversas das exercidas anteriormente, o trabalho braçal se reservou principalmente aos negros antes escravizados. Sendo certo que tais funções foram exercidas por esses indivíduos principalmente por conta de sua raça, seria mais adequado falar em discriminação racial nesta hipótese, ao invés de discriminação em função do labor exercido.

Assim, tem-se que no Brasil as relações de poder que impõem o racismo ambiental a negros e outras minorias étnicas estariam mascaradas, além de agravadas, pela profunda desigualdade social desenvolvida por processos políticos produtores de discriminação racial, bem como pelas práticas de racismo institucionalizado no país.

É possível falar em duas modalidades de segregação: voluntária e involuntária. Enquanto na primeira o indivíduo, por iniciativa própria e de forma autônoma, decide habitar determinada área da urbe, na segunda, é por razões heterônomas que ele é levado a habitar ou deslocar-se de determinados espaços (Negri, 2008). De acordo com Villaça (2001), as cidades brasileiras se organizaram pela segunda modalidade de segregação. 
Vasconcelos (2004) apresenta que o processo de segregação, inicialmente calcado na língua e na cultura, posteriormente seria determinado com base na raça. Considerando que não há como se controlar plenamente o crescimento urbano, fica à cargo do mercado imobiliário e das condições de aquisição de propriedade privada as regras últimas que afetam a possibilidade de acesso à moradia nas diversas regiões urbanas. Isso reforça a crença de que haveria uma organização natural do espaço, impessoalmente organizado por uma entidade invisível e sem um projeto determinado - o mercado - ignorando-se todos os elementos que impactam o acesso àquele espaço. Até mesmo o mais óbvio desses elementos - o preço da terra - poderia passar despercebido se não levado em consideração o seguinte: a) a história demonstra que a pobreza no Brasil se entrelaça com a questão racial; b) o meio afeta o valor da terra, sendo que por vezes a disposição do meio é realizada por instituições contaminadas estruturalmente pelo racismo.

Apontando entendimento diverso do apresentado no parágrafo supra, veja-se o assim sintetizado por Negri (2008):

"Ainda fazendo uma analogia com o 'mundo natural', a Escola
de Chicago criou os conceitos de competição e dominância para
analisar as várias atividades urbanas (comercial, industrial e
residencial), explicando o alto valor da terra em determinadas
áreas pela grande competição entre os gêneros de atividades por
localizações vantajosas, ou seja, nas palavras de hoje, o valor da
terra seria dado única e exclusivamente pelo 'mercado'. [...] O
maior equívoco desta escola foi o de ter tomado para a
sociedade uma teoria construída para os elementos naturais e ter
construído bases para a 'naturalização' das relações sociais nas
cidades. A segregação sócio-espacial foi tomada como algo
inerente a cidades, através de questões de cunho racial, étnico e
cultural. Como se ser segregado ou não fizesse parte do
cotidiano do espaço urbano, das relações 'naturais' entre as
pessoas, ou seja, somente aquele que se adaptasse mais
facilmente e mais rapidamente ao modo de vida urbano poderia
sair-se melhor e, consequentemente, habitar as melhores áreas e
ter as melhores oportunidades de trabalho e renda" (Negri,
2008 , p. 134-135) Levando-se em conta o aspecto já levantado, é certo que a organização do espaço urbano se dá de forma menos natural e aleatória do que econômica. Desta feita, imperativo observar que terá elevada 
importância para a forma com a qual a população se distribui no espaço urbano a capacidade de acúmulo de capital que cada indivíduo é capaz de realizar. Pertinente, por conseguinte, ressaltar que "morar um bairro periférico de baixa renda hoje significa muito mais do que apenas ser segregado, significa ter oportunidades desiguais em nível social, econômico, educacional, renda, cultual" (ibid., p. 136). O resultado da segregação é produção, dentro da cidade, de regiões com elevado grau de homogeneização socioeconômica e racial mas que apresentam alto teor de disparidade entre si, frequentemente materializado na prestação e acesso a bens e serviços públicos em geral.

Há que se ter em vista que a disposição do espaço guarda direta proporção com mecanismos de interação social, "a partir da qual os indivíduos derivam seus valores, expectativas, hábitos de consumo, capacidade de se fazer valer (market capacity) e estado de consciência" (ibid., p. 137). Veja-se aqui que resta demonstrada a relação entre o processo histórico de ocupação territorial e o seu papel determinante não só na naturalização de uma posição social de inferioridade da população negra como também no processo de institucionalização da discriminação, na medida em que as condições determinantes de acesso a terra não visibilizam obstáculos criados com fundamento étnico-racial. A relação é institucionalizada, naturalizada e perpetuada, vez que a segregação já estabelecida implica também o acesso diferenciado a recursos escassos e necessários para que seja possível adquirir oportunidades que permitam a ascensão social.

A coincidência da discriminação racial com a histórica imposição de condições desvantajosas de avanço econômico a essa população colabora com a manutenção e agravamento da segregação espacial. Não raro, é possível verificar que determinadas regiões, cuja população tem menores condições de resistir à pressão de agentes econômicos e do Estado, além de piores condições ambientais - como saneamento básico e mobilidade deficientes - suportam a imposição desproporcional de agentes poluentes. 
Com efeito, formam-se verdadeiras "zonas de sacrifício" que concentram uma numerosa quantidade de atividades poluidoras numa mesma localidade, impondo à população local seus efeitos negativos, como o aparecimento de problemas de saúde.

O Estado é um importantíssimo agente no processo urbano, eis que não há como produzir um padrão urbanístico sem a sua participação-e isto independe do fato de o referido padrão assumir ou não caráter segregatório (Marcuse, 2004). Ocorre que o Estado é capaz de mobilizar todo um aparato institucional para moldar o espaço urbano, desde leis que regulem o direito de propriedade ao uso da força através de aparelhos de coerção social, ademais de toda uma configuração que envolve obras de implantação de infraestrutura, tais como a pavimentação de ruas, construção de estradas, iluminação pública, etc. (Negri, 2008).

Há, quando menos da intervenção direta, aceitação tácita do Estado, que se queda inerte diante da perpetuação de padrões coloniais de dominação e organização socioespacial. Ademais do mercado imobiliário, que dá vazão aos anseios locacionais da classe dominante, há fundamental papel do Estado no que concerne à concretização da segregação espacial, máxime porque é estatal o controle da infraestrutura urbana, da localização de aparelhos essenciais à cidadania e ao pleno uso do espaço, bem como da legislação que regula o uso e ocupação do solo urbano.

$\mathrm{Na}$ América Latina os padrões de segregação passaram por transformações. Inicialmente marcado, durante a sociedade colonial, pela dinâmica estabelecida com a formação dos engenhos de açúcar, posteriormente - aproximadamente entre 1850 e 1930 -, com avanços tecnológicos que revolucionaram a mobilidade urbana, esse padrão se modificou, permitindo que habitações de classe média alta começassem a se distanciar do centro da cidade. Essa desocupação permite que se aloje no espaço a população de baixa renda, formando cortiços. A partir da década de trinta, como leciona Negri (2008), o interesse da classe alta se centra em áreas dotadas de amenidades, paralelamente ao fluxo migratório que atraia 
principalmente trabalhadores rurais para os centros urbanos. Prolifera-se, então, a ocupação de periferias, a formação de favelas, loteamentos e conjuntos habitacionais populares financiados pelo Estado.

De acordo com Negri (2008),

"Atualmente, este modelo centro-periferia (paradigma que sobreviveu dos anos 1940 a 1980) tem sido muito contestado pelo modelo fractal, que apresenta uma aproximação física entre as classes sociais, porém, um grande distanciamento psicológico e social" (Negri, 2008, p. 142).

No mesmo sentido afirma Caldeira (2000):

"Sobrepostas ao padrão centro-periferia, as transformações recentes estão gerando espaços nos quais os diferentes grupos sociais estão muitas vezes próximos, mas estão separados por muros e tecnologias de segurança, e tendem a não circular ou interagir em áreas comuns. O principal instrumento desse novo padrão de segregação espacial é o que chamo de 'enclaves fortificados'. Trata-se de espaços privatizados, fechados e monitorados para residência, consumo, lazer e trabalho. A sua principal justificação é o medo do crime violento. Esses novos espaços atraem aqueles que estão abandonando a esfera pública tradicional das ruas para os pobres, os 'marginalizados' e os sem-teto" (Caldeira, 2000, p. 211) ${ }^{76}$

A segregação de que ora se fala nada é senão reflexo de um profundo processo de desigualdade social. A despeito de [as diferentes nações] experimentarem distinções e particularidades históricas, o modelo de segregação latino-americano possui um núcleo comum: a relação de dominação colonial, que fundou a base dos critérios de segregação que viria a organizar essas sociedades. Há a tendência de grupos socialmente homogêneos - vale dizer, não se fala aqui em absoluta homogeneidade - de se agruparem em proximidade, havendo baixa interação entre grupos socialmente distintos.

É possível traçar um dos indicadores embrionários do racismo ambiental no contexto urbano à Lei de Terras de 1850, que criaria uma série

\footnotetext{
${ }^{76}$ Merece destaque a correlação existente entre a caracterização da rua como território negro (Rolnik, 1989), a marginalização da população negra e o seu encarceramento em massa como resultado da política criminal adotada nas últimas décadas (Santos, 2015) e a produção desses espaços de segregação espacial. É certo que os afetos exercem grande poder sobre os indivíduos e a vida em sociedade. $\mathrm{O}$ medo, em particular, sobretudo quando inflamado, alimentado, tem enorme potencial desagregador das relações humanas e é capaz de obstruir a formação de laços de fraternidade, dificultando encontros ampliadores de potência. Veja-se o relato trazido por Vargas (2005) a respeito do caso da comunidade do Jacarezinho, no Rio de Janeiro, que denota a complexidade da questão.
} 
de restrições de acesso à terra para a camada de mais baixa renda da população - cujo caráter racial era bem definido. A emergência do trabalho livre, sem qualquer política de inclusão social, mas ao revés, acompanhada de esforços de exclusão e genocídio pelo embranquecimento, contribuiria para o empobrecimento e formação de núcleos de segregação da população não branca. ${ }^{77}$

Há que se notar, portanto, o papel do Estado na concretização desse modelo de segregação e a importância da atividade estatal para o seu desfazimento. Deve-se considerar que diversos elementos do espectro de variáveis que organizam o espaço urbano sofrem forte influência - direta ou indireta - da atuação estatal. Note-se, sobretudo, que integra a atividade estatal o design de um certo projeto de cidade e prestação de uma série de serviços essenciais à sua concretização. A segregação, por sua vez, surge justamente a partir da implementação de um certo projeto de cidade: que produz espaços de exclusão e não fomenta a interação de grupos sociais distintos, antes, pelo contrário, os distribui em espaços geográficos distintos, muito bem definidos pela intensidade e forma de manifestação da presença do Estado mesmo quando contíguos.

Como evidenciado, a forma de segregação apontada impacta diretamente o exercício da cidadania, na medida em que as distinções impostas determinam um diferente acesso a políticas públicas e ao bemestar social, vez que possuem direta relação com a localização espacial e a renda. É necessário combater um projeto de cidade que historicamente vem buscando assegurar - quiçá acentuar - um padrão de segregação marcado pela discriminação racial e de classe.

\footnotetext{
${ }^{77}$ A Lei de Terras, "apesar de muito conhecida por criar valor de troca para o solo rural, também o fez em relação ao solo urbano. A autora lembra que esta lei diferencia pela primeira vez na história brasileira o que é solo público e o que é solo privado" (Maricato apud Negri, 2008, p. 147).
} 


\section{Capítulo 3: O combate ao racismo ambiental no Brasil}

\subsection{A luta por justiça ambiental no Brasil}

Discussões que relacionam a justiça ambiental e a justiça social começam a ter visibilidade no Brasil no final do séc. XX. Em 1998, integrantes do Movimento de Justiça Ambiental vieram ao país buscando compartilhar a experiência norte-americana, oferecer apoio e formar alianças com organizações locais da sociedade civil interessadas em combater a "exportação da injustiça ambiental". ${ }^{78}$

Embora o uso da expressão "justiça ambiental" no vocabulário dos movimentos sociais brasileiros seja relativamente recente, lutas por pautas abrangidas pela justiça socioambiental já vinham sendo travadas no país. Com efeito, desde a década de 1970 é possível traçar movimentos contrários à utilização de agrotóxicos na produção agrícola pelos danos provocados ao meio ambiente e à saúde humana; à exploração predatória da Amazônia e aos ônus que impõe às populações tradicionais e ribeirinhas, dentre outros. No campo das relações raciais destacam-se esforços de integração do negro à sociedade na desde a década de 1930, a partir de um olhar sensível à segregação socioespacial. ${ }^{79}$ A Frente Negra Brasileira defendia a reorganização do território negro como condição para o combate à desigualdade entre negros e brancos. ${ }^{80}$

\footnotetext{
78 "Uma primeira iniciativa de releitura da experiência norte-americana por entidades brasileiras deu-se pela realização de um material de discussão elaborado e publicado por iniciativa da Ong Ibase, da representação da Comissão de Meio Ambiente da Central Sindical CUT no Rio de Janeiro e de grupos de pesquisa do Ippur/UFRJ. Os três volumes da série Sindicalismo e justiça ambiental (Ibase/CUT-RJ/Ippur-UFRJ, 2000) tiveram circulação e impacto restrito, mas estimularam outros grupos da universidade, do mundo das ONG e do sindicalismo a explorar o veio de tal debate, o que levou à organização do Seminário Internacional Justiça Ambiental e Cidadania, realizado em setembro de 2001 na cidade de Niterói”" (Acserald, 2010, p. 111).

${ }^{79}$ Evidentemente, não se ignora a existência de formas de resistência negra e seus esforços de integração ao corpo social e ao mercado desde o período colonial. O destaque realizado denota escolha que tão-só se presta a exemplificar esse esforço dentro do recorte efetuado no presente trabalho, eis que empreendida no período abordado e relativa à segregação espacial racialmente discriminatória.

${ }^{80}$ De acordo com Rolnik (1989, p. 45), uma das iniciativas da FNB em São Paulo foi a compra de terrenos em loteamentos na periferia com o propósito de viabilizar a formação de bairros negros com estrutura para o núcleo familiar e a vida em comunidade.
} 
É a partir do início do séc. XXI que se observa maior intensificação nas discussões que associam as problemáticas ambientais com outras relevantes questões de justiça social, como a questão da moradia, do emprego e da distribuição de renda. Em 2001, no campus da Universidade Federal Fluminense, localizado na cidade de Niterói/RJ, foi criada a Rede Brasileira de Justiça Ambiental, que teve seu manifesto apresentado no Colóquio Internacional sobre Justiça Ambiental, Trabalho e Cidadania, realizado em 2001. A Rede se consolidaria no ano seguinte como um espaço de debate, denúncias, mobilizações e elaboração de alternativas e estratégias para o combate à injustiça ambiental, bem como de articulação de ações de resistência desenvolvidas por movimentos sociais, ONGs, associações de moradores, sindicatos, pesquisadores universitários e núcleos de instituições pesquisa e ensino. ${ }^{81} \mathrm{~A}$ realização do evento contou com a presença de representantes de movimentos sociais, pesquisadores e ambientalistas de todo o Brasil e dos Estados Unidos, incluindo Bullard, importante referência na área. ${ }^{82}$

Juntamente à criação da Rede Brasileira de Justiça Ambiental foi elaborada a Declaração de Princípios da Rede Brasileira de Justiça Ambiental, que define a luta por justiça ambiental no Brasil como o conjunto de princípios e práticas que:

“(a) asseguram que nenhum grupo social, seja ele étnico, racial ou de classe, suporte uma parcela desproporcional das consequências ambientais negativas de operações econômicas, de decisões de políticas e programas federais, estaduais, locais, assim como da ausência ou omissão de tais políticas;

(b) asseguram o acesso justo e equitativo, direto e indireto, aos recursos ambientais do país;

(c) asseguram amplo acesso às informações relevantes sobre o uso dos recursos ambientais e a destinação de rejeitos e localização de fontes de riscos ambientais, bem como processos democráticos e participativos na definição de políticas, planos, programas e projetos que lhes dizem respeito;

\footnotetext{
${ }^{81}$ Sobre a Rede Brasileira de Justiça Ambiental consultar <http://www.justicaambiental.org.br〉.

${ }^{82} \mathrm{O}$ Colóquio logrou promover debates de cunho acadêmico e político a respeito da promoção da justiça ambiental no país e visava "[...] ampliar o diálogo e a articulação entre sindicatos, movimentos sociais, ambientalistas e pesquisadores, no sentido de estimular o fortalecimento da luta por justiça ambiental no Brasil”" (Acserald et al apud Rammê, 2012, p. 49).
} 
(d) favorecem a constituição de sujeitos coletivos de direitos, movimentos sociais e organizações populares para serem protagonistas na construção de modelos alternativos de desenvolvimento, que assegurem a democratização do acesso aos recursos ambientais e a sustentabilidade do seu uso" (Rammê, 2012, p. 50)

O enfrentamento da injustiça ambiental no Brasil, como leciona Herculano,

\begin{abstract}
"implica desenvolver articuladamente as lutas ambientais e sociais: não se trata de buscar o deslocamento espacial das práticas danosas para áreas onde a sociedade esteja menos organizada, mas sim de democratizar todas as decisões relativas à localização e às implicações ambientais e sanitárias das práticas produtivas e dos grandes projetos econômicos e de infraestrutura." (Herculano, 2008, p. 13)
\end{abstract}

Rammê (2012) aponta a existência de pelo menos quatro fatores que provocam a execução e perpetuação de práticas de injustiça ambiental estas se aplicariam não só a um contexto doméstico de violações, mas podem ser escaladas às relações forjadas em nível global. Todas as causas apontadas se inter-relacionam, formando um verdadeiro sistema que funciona como plataforma de transferência dos prejuízos ambientais para a coletividade.

A produção de externalidades ambientais negativas que não só provocam danos ecológicos como a todo um espectro de direitos fundamentais é um dado real. Igualmente, no atual modelo produtivo, os ônus produzidos precisam ser suportados - isto é, alguém precisa arcar com a responsabilidade e os custos da sua produção. Ao revés de haver a incorporação do respectivo ônus ao processo produtivo - seja arcando com técnicas não poluentes, seja com o emprego de mecanismos que aplaquem os impactos produzidos -, há a externalização de custos pelos agentes produtores, o que barateia a produção através do repasse do encargo relativo aos ônus ambientais ao Estado, à coletividade ou à natureza. ${ }^{83}$

O primeiro fator elencado pelo autor como provocador de injustiça ambiental seria a "transformação do consumo numa prática antropológica"

\footnotetext{
${ }^{83}$ Daí advém uma série de críticas de teóricos da justiça ambiental ao atual modelo econômico; “[...] embora o núcleo da crise provocada pelo capitalismo na conjuntura da globalização neoliberal seja econômico, é no meio ambiente e nas relações socioambientais que os resultados da atual conjuntura econômica se mostram mais avassaladores" (Rammê, 2012, p. 60).
} 
(Rammê, 2012, p. 62), traço do atual curso de desenvolvimento do modelo econômico capitalista. A criação de mercados de massa e exponencial elevação das práticas de consumo acarretariam uma série de problemas ecológicos - como o aumento da produção de lixo - como distorções em hábitos sociais que impactam o gozo da liberdade econômica individual. Isto, porquanto se fomentaria o consumo ostensivo e da captura do poder de compra através da "invenção de necessidades": é neste aspecto que assume importância a publicidade e o marketing, empenhados em resignificar a felicidade e a inclusão social pela propriedade de determinados bens. No que concerne o consumo, de acordo com Acserald, Mello e Bezerra (2009), "[...] o acesso desigual ao meio ambiente vai expressar-se na extrema concentração de bens em poucas mãos: estima-se que $20 \%$ da população mundial consome entre $70 \%$ e $80 \%$ dos recursos do mundo" (Acserald et al, 2009 , p. 75). ${ }^{84}$

O curso de desenvolvimento desse modelo viabilizou a formação de mercados globais e entidades transnacionais que são capazes de condensar poderes que rivalizam - e, por vezes, ultrapassam - o poder e controle estatal. O que indica o segundo fator elencado por Rammê (2012): "a soberania dos mercados financeiros e o enfraquecimento do Estado" (Rammê, 2012, p. 63). Há ambiguidades na análise do papel do Estado quando se trata da promoção da justiça ambiental, porque: de um lado, há o desafio da construção e preservação de instituições que assegurem a manutenção de um Estado forte o suficiente para repelir externalidades que ameacem a liberdade dos cidadãos; de outro, o Estado, em muitos casos, alia-se ao capital privado e atua no sentido de facilitar ou viabilizar contextos de violação ou, em outros casos, omite-se permitindo a perpetuação dessas violações.

\footnotetext{
84 De acordo com a United Nations Development Program (UNDP), esses mesmos 20\% da população mundial seriam os responsáveis pelo consumo de $45 \%$ de toda carne e peixe produzidos, bem como pelo consumo de $68 \%$ da eletricidade no mundo. Além disso, essa mesma parcela da população consumiria $84 \%$ do papel fabricado e $87 \%$ de todos os automóveis ao redor do globo. Os resultados constam do Human Development Report, publicado pela Oxford Univ. Press, em 1992.
} 
De acordo com Rammê (2012), a hegemonia assumida pelo mercado financeiro e o consecutivo enfraquecimento do Estado acarretaria a flexibilização de direitos sociais, a partir do que seriam chanceladas práticas de injustiça ambiental. Esse enfraquecimento, argumenta, decorreria "tanto da adoção de políticas públicas insatisfatórias, quanto da omissão na adoção de políticas voltadas ao enfrentamento de injustiças ambientais" (ibid., p. 63). A construção de um Estado forte, com instituições estáveis, capaz de repelir ameaças externas, não é um problema novo no campo da ciência política.

Com efeito, entende-se que o caminho que apresenta alternativas para os novos problemas trazidos pela atual sistemática econômica global passa pela constatação de que cumpre ao Estado reunir os meios necessários para a sua conservação. Isto implica necessariamente o combate aos intentos de injustiça ambiental promovidos por entes públicos e privados, eis que a autonomia e liberdade estatal frente a esses atores somente é possível, segura e duradoura na mesma medida em que o povo é livre. As práticas de injustiça ambiental, como visto, não só refletem como agravam desigualdades sociais, bem como minam e criam obstáculos a ampliação e exercício de uma série de liberdades individuais.

Outro fator seria a desigual aplicação da legislação ambiental, o que, como apresentado anteriormente, foi empiricamente aferido nos estudos acerca do racismo ambiental nos Estados Unidos. A esse respeito, Acserald, Mello e Bezerra afirmam que a legislação ambiental "[...] é mais rigidamente aplicada quando se tratam de pequenos agricultores, pescadores, e extrativistas do que quando se trata do agronegócio e de grandes corporações industriais" (Acserald et al, 2009, p. 79). A desigualdade ambiental pode se dar tanto por uma proteção ambiental deficiente - desigual - quanto pelo acesso desigual a recursos ambientais. ${ }^{85}$

\footnotetext{
${ }^{85} \mathrm{O}$ autor traz à baila exemplo da distribuição de resíduos tóxicos no Rio de Janeiro: "Segundo estimativas da Comissão de Meio Ambiente da Assembleia Legislativa do Estado do Rio de Janeiro, são produzidos anualmente no Estado 240 mil toneladas de resíduos tóxicos. Desse volume, estima-se não haver controle algum por parte das agências ambientais sobre 120 mil toneladas (50\%). A Fundação Estadual de Engenharia do Meio Ambiente (FEEMA), órgão
} 
É que

"a constatação da desigualdade ambiental, tanto em termos de proteção desigual como de acesso desigual, nos leva a reconhecer que o que está em jogo não é simplesmente a sustentabilidade dos recursos e do meio ambiente, ou as escolhas técnicas descoladas da dinâmica da sociedade, mas sim as formas sociais de apropriação, uso e mau uso desses recursos e desse ambiente." (ibid., p. 76).

Um quarto fator apontado por Rammê (2012) seria a "neutralização da crítica potencial", que pode se manifestar de múltiplas formas:

"Uma forma decorre da ação estratégica de grandes setores da economia global que incutem a ideia de que a contaminação e a poluição são um mal necessário decorrente da necessidade de desenvolvimento. Outra forma é a prática, por grandes empresas e indústrias, de ações políticas simpáticas aos olhos de comunidades carentes, visando a evitar o surgimento de manifestações que venham a questionar as condições de funcionamento de atividades poluidoras ao meio ambiente ou prejudiciais à saúde das comunidades vizinhas. Também os discursos de negação das injustiças ambientais, de culpabilização dos pobres, de descrédito ou ridicularização de reivindicações de cunho ecológico ou cultural, são exemplos de estratégias de neutralização de críticas e reivindicações contra injustiças ambientais" (Rammê, 2012, p. 64)

Acserald critica fortemente o chamado sistema de "neutralização de críticas" que agentes privados utilizariam atualmente. Para o autor, a "modernização tecnológica" fomentada por esses atores visaria tão somente compatibilizar o crescimento econômico com as preocupações ecológicas, de modo que estas não venham a obstruí-lo, impedindo a perda da superioridade relativa da qual gozam os agentes dominantes. Não haveria, portanto, uma preocupação real em combater efetivamente e por completo as mazelas da problemática ambiental, efetivamente promovendo um modelo sustentável de desenvolvimento e que aplacasse todas as

ambiental do Estado, por sua vez, estima haver 24 mil indústrias funcionando sem controle das agências ambientais, muitas delas contribuindo para a produção desse lixo tóxico. Mas além das fontes incontroladas situados no próprio Estado, registra-se um fluxo de resíduos proveniente de fora, de São Paulo, Minas Gerais e Bahia, um deslocamento licenciado para a queima em fornos do Rio de Janeiro, mas que, em parte, estima-se, para evitar o pagamento dos custos de incineração, resulta no lançamento em despejos clandestinos ao longo do percurso, no usufruto das fragilidades do aparelho fiscalizatório. Esses despejos clandestinos, bem como a alocação de plantas industriais que oferecem maior risco, concentram-se efetivamente em áreas pobres da periferia metropolitana da cidade do Rio de Janeiro" (Acserald et al, 2009, p. 80). 
externalidades negativas hoje produzidas por práticas de injustiça ambiental. ${ }^{86}$

Com a difusão da noção de responsabilidade social das empresas, tendo em vista que muitos dos agentes industriais se localizam em áreas empobrecidas, os entes econômicos buscam, em contrapartida, construir creches, escolas e postos de saúde, por exemplo. Dessa forma, reduz-se a capacidade de resistência da população local, eis que, ante a ameaça de retirada dos poluidores da localidade, a prestação de serviços básicos e essenciais também se encontraria ameaçada, haja vista a frequente omissão do Estado em promovê-la. Assim, além da chantagem econômica e trabalhista, adiciona-se elementos que desmotivem a população a se insurgir contra os empreendimentos. As chantagens empregadas por agentes econômicos são bem explicadas por Acserald:

\begin{abstract}
"a força desses agentes reside na "chantagem locacional" pela qual os grandes investidores envolvem, quando não submetem a todos aqueles que buscam o emprego, a geração de divisas e a receita pública a qualquer custo. No plano nacional, se não obtiverem vantagens financeiras, liberdade e remessa de lucros, estabilidade, etc., os capitais internacionalizados ameaçam se "deslocalizar" para outros países. No plano subnacional, se não obtiverem vantagens fiscais, terreno de graça, flexibilização de normas ambientais, urbanísticas e sociais, também se "deslocalizam", penalizando, consequentemente, os Estados e municípios onde é maior o empenho em preservar conquistas sociais e ambientais. Ao mesmo tempo, ao escolherem o espaço mais rentável onde se relocalizar (ou seja, aqueles locais onde conseguem obter vantagens fiscais e ambientais), acabam premiando com seus recursos os Estados e municípios onde é menor o nível de organização da sociedade e mais débil o
\end{abstract}

\footnotetext{
86 A crítica apresentada se relaciona também ao questionamento da cultura do consumismo fomentada pelo modelo capitalista. O capitalismo de consumo, de acordo com Lipovetsky, passaria por três eras: (a) a primeira delas entre 1880 e 1945, em que os mercados locais seriam substituídos por mercados nacionais, impactando os meios de produção, transporte e comunicação, e iniciando o chamado processo de "democratização do desejo" - o consumo se tornaria sinônimo de felicidade, simbolizando status social; (b) a segunda fase é descrita como a emergência da "sociedade de consumo de massa", do pós-guerra à década de 1970; o crescimento econômico, a elevação da produtividade e do poder de compra ampliaria significativamente o mercado consumidor - é nessa fase que haveria o "boom" de diversificação de produtos e redução da sua durabilidade, elevando a produção de lixo; (c) a terceira fase é a da "sociedade de hiperconsumo", que potencializa a produção, a publicidade, os sonhos, o descarte, a produção de lixo e a poluição ambiental - seriam incorporados à sociedade de consumo mesmo os mais pobres, que priorizariam a obtenção de objetos "desejo de consumo" como forma de evitar maior "humilhação social" e tentativa de diminuir o gap que marca uma sociedade profundamente hierarquizada; É que aqueles que não são capazes de consumir determinados produtos experimentam verdadeira exclusão social, sendo estigmatizados como pertencentes a uma "subclasse social". (Rammê, 2012, p. 56-58)
} 
esforço em assegurar o respeito às conquistas legais. Ou seja, nesse quadro político-institucional, os capitais conseguem "internalizar a capacidade de desorganizar a sociedade", punindo com a falta de investimentos os espaços mais organizados, e premiando, em contrapartida, com seus recursos, os espaços menos organizados" (Acserald, 2010, p. 113).

Fortaleceu-se a aposta na modernização tecnológica como principal ferramenta para a solução das problemáticas ambientais. Com isso, foca-se principalmente na redução de efeitos globais, em detrimento de questões sociais e políticas tais como a concentração de emissão de poluentes em áreas específicas - que frequentemente possuem legislação ambiental flexível e dispensam o uso de técnicas ou equipamentos menos danosos. Trata-se de um processo pelo qual as empresas absorvem as críticas realizadas e, já as antecipando, moldam um mecanismo de resposta adequado à economia de mercado e seus paradigmas atuais. Essa corrente foca principalmente em parâmetros técnico-científicos de aferição e neutralização da poluição ambiental.

Da chantagem locacional exsurge também um quinto fator - que recebeu destaque no presente trabalho por sua relação com as práticas de racismo ambiental - a segregação socioespacial. ${ }^{87}$ A respeito da segregação socioespacial promovida pelas práticas de injustiça ambiental destacam Acserald, Mello e Bezerra (2009):

"As elites socioeconômicas são mais capazes de assegurar que seus interesses sejam satisfeitos em primeiro lugar nos conflitos de localização das atividades. Os mais ricos tendem a escapar dos riscos ambientais residindo em áreas mais protegidas, cujo solo tem maior valor. Aos pobres correspondem condições ambientais de existência mais degradadas por um duplo mecanismo: 1) empurram-se as populações de menor renda para áreas de maior risco e menos atendidas por infraestrutura e 2) situam-se fontes de risco e de grande impacto ecológico em áreas habitadas por grupos sociais menos capazes de se fazer ouvir no espaço público e de se deslocar para fora do círculo de risco" (Acserald et al, 2009, p. 78).

\footnotetext{
${ }^{87}$ Não se nega que a questão apresenta desafios: "Não há dúvida de que o locus por excelência da evidenciação da injustiça ambiental está exatamente nos contextos intra-urbanos. A verificação de dados internacionais, nacionais, regionais ou até municipais acerca da distribuição dos riscos ecológicos, de um modo geral, não explicita sua sobreposição aos mais pobres. Isto se dá porque a coincidência socioespacial entre privação social e privação ambiental costuma ficar encoberta pelas "médias" alcançadas por aquele dado território em geral, em termos de renda ou de provisão de serviços" (ACSERALD et al, 2009, p. 50)
} 
A produção da desigualdade ambiental no campo da segregação socioespacial se relaciona com a chantagem locacional na medida em que grandes empresas ou agentes privados

“[...] impõem condições ao Poder Público (isenções fiscais, favores fundiários, flexibilização de normas ambientais, urbanísticas, etc.), acenando com a possibilidade de, caso não atendidas as condições impostas, se instalarem em outra cidade, estado ou país" (Rammê, 2012, p. 63).

Do excerto supra se verifica o entrelace entre os cinco fatores apontados. A questão da segregação socioespacial, por exemplo, guarda íntima relação com o enfraquecimento do Estado e, em grande medida, com o modo como o grau desse enfraquecimento viabiliza a flexibilização de normas prescritas, direitos sociais e difusos. Todos esses aspectos confluem também para a concretização e manutenção de práticas de racismo ambiental.

É de se notar que a luta por justiça ambiental, no Brasil, volta-se para a justa distribuição do espaço ambiental coletivo e o combate a violações de direitos fundamentais relacionadas a problemáticas de degradação ambiental, de todos os seres humanos, inclusive os de populações marginalizadas e de baixa renda (Rammê, 2012). Válido traçar uma breve cronologia de pontos significativos da luta por justiça ambiental no Brasil a partir da criação da Rede Brasileira de Justiça Ambiental.

Desde a criação, a Rede se envolveu em uma série de casos, denúncias e reivindicações relativas a promoção da justiça ambiental:

“[...] campanhas contra grandes empreendimentos, em especial contra barragens e monoculturas; pelo banimento de substâncias tóxicas; contra a violência no campo, onde grupos indígenas, quilombolas e populações que vivem do extrativismo são vítimas de agressões que produzem desigualdade ambiental; de questionamento da ideologia do crescimento econômico a qualquer custo" (Acserald et al, 2009, p. 44)

Dois anos após o Colóquio Internacional sobre Justiça Ambiental, Trabalho e Cidadania, a Rede Brasileira de Justiça Ambiental se mobilizou contra a transferência de resíduos sólidos produzidos no Estado de São Paulo para a Bahia, onde a legislação pertinente à incineração de dejetos era menos rígida. Foi criado um grupo de trabalho que iniciou uma campanha 
em prol da articulação de movimentos de resistência à deslocalização de riscos e passivos ambientais (Rammê, 2012). É bem de ver que a questão da transferência dessas externalidades negativas ocorre tanto em nível doméstico quanto internacional. A partir de uma "[...] resistência integrada à deslocalização de passivos e riscos ambientais" (Acserald et al, 2009, p. 43), "elaborou-se um posicionamento coletivo que motivou outras ações contra a exportação das injustiças ambientais" (ibid., p. 43)

Em 2004, a Rede Brasileira de Justiça Ambiental associou-se a movimentos internacionais de combate a exportação de injustiças ambientais para promover uma campanha contrária à exploração de petróleo em terras indígenas no Equador pela Petrobras. A empresa pretendia iniciar a exploração de petróleo em áreas pertencentes ao Parque Nacional Yasuni e no território indígena Huaorani. Haja vista que no Brasil é vedada a exploração em tais localidades, a Rede e os movimentos sociais por justiça ambiental detectaram a adoção de um duplo-padrão - fenômeno frequentemente observado especialmente em casos de exportação de injustiça ambiental. Assim, "[...] impedida em seu país de explorar áreas reconhecidamente frágeis, como são os parques nacionais e os territórios indígenas, a empresa se aproveitava de uma regulação mais permissiva no Equador" (ibid., p. 43).

Já em 2006 a organização se mobilizou contra a exportação, pela União Europeia, de externalidades ambientais para o Brasil. A UE acionou a Organização Mundial do Comércio em virtude da proibição no Brasil de importação de pneus reformados por razões ambientais e de saúde pública. Foi solicitada a abertura de um painel arbitral com o objetivo de obrigar o Brasil a receber os pneus a despeito da vedação legislativa para sua entrada no país. A motivação principal era o fato de que os próprios países integrantes da União não poderiam mantê-los em virtude de uma diretiva interna da própria União Europeia que impedia "dispor de seus pneus inservíveis nos aterros sanitários da região" (ibid., p. 43), bem como impôs a redução de queimadas com o fito de preservar a atmosfera. 
A postura da Rede, observa-se, não se confunde com a dos movimentos anteriormente apresentados de "not in my backyard", visto que não se propõe o deslocamento desses passivos. No último caso, forjou-se uma aliança com acadêmicos da Fiocruz, movimentos sociais de âmbito nacional e internacional, para debater os destinos desses dejetos e elaborar propostas.

Válido, para a caracterização do "estado da arte" do combate à injustiça ambiental no Brasil, apontar estudos emblemáticos que tem sido realizados nesse campo - para além dos trabalhos dos pesquisadores anteriormente indicados.

A Fiocruz em parceria com a Fase e com o apoio do Departamento de Saúde Ambiental e Saúde do Trabalhador do Ministério da Saúde elaborou o Mapa da Injustiça Ambiental e Saúde no Brasil, “[...] um amplo e aprofundado estudo que objetiva sistematizar e socializar as informações disponíveis sobre a situação da injustiça ambiental no Brasil" (Rammê, 2012, p. 52). ${ }^{88}$ Os resultados iniciais datam de março de $2010^{89}$ e denotam que as regiões Norte e Nordeste concentrariam aproximadamente metade de todos os conflitos analisados. Quanto à região Sudeste, a conclusão a que se chegou foi a de que a injustiça ambiental guardaria relação com o processo histórico de ocupação da terra combinado ao processo de industrialização sofrido pela região. No mapa de conflitos, a região Sudeste comportaria $27,7 \%$ do total nacional contra $29,45 \%$ da região Nordeste e $21,28 \%$ do Norte do país. Com isso, o relatório também concluiria que a maioria dos

\footnotetext{
${ }^{88} \mathrm{O}$ projeto realizou o levantamento de 15 a 30 casos por estado, sendo contabilizadas denúncias a partir de janeiro de 2006, inclusive aquelas originadas em fatos anteriores, levando em consideração: a) o tipo de população atingida e o local do conflito (povos indígenas, operários, quilombolas, agricultores familiares, moradores em encostas, ribeirinhos, pescadores e outros tantos, urbanos ou rurais); b) o tipo de dano à saúde (contaminação por chumbo, desnutrição, violência física, dentre outros) e de agravo ambiental (desmatamento, queimada, contaminação do solo e das águas por agrotóxicos, por exemplo); c) a síntese do conflito e o contexto ampliado do mesmo, apresentando os principais responsáveis pelo conflito, as entidades e populações envolvidas na luta por justiça ambiental, os apoios recebidos ou não (como participação de órgãos governamentais, do Ministério Público e de parceiros da sociedade civil), as soluções buscadas e/ou encontradas; d) os principais documentos e fontes de pesquisa usadas na pesquisa sobre o caso (MAPA DA INJUSTIÇA AMBIENTAL E SAÚDE NO BRASIL, 2010, metodologia).

89 Os resultados estão disponíveis no sítio $\langle$ http://www.conflitoambiental.icict.fiocruz.br/index.php?pag=resumo〉. Acesso em 15 de nov. de 2016.
} 
conflitos se daria em áreas rurais, atingindo uma diversidade de grupos distintos, tais como indígenas, quilombolas, extrativistas, pescadores e até pequenos agricultores. Por outro lado, destaca-se a previsão de que

"[...] várias lutas urbanas no país envolvendo questões de saúde, meio ambiente, moradia, saneamento, qualidade de vida, direitos humanos e cidadania ainda não incorporaram o conceito de justiça ambiental, numa trajetória diferente de países como os EUA, onde tais lutas urbanas marcaram o início dos movimentos contra o racismo e a injustiça ambiental. O desenvolvimento de movimentos por justiça ambiental, por moradia digna e por direitos humanos nas cidades brasileiras, em especial nos territórios das favelas e áreas afetadas por lixões, fábricas, poluição atmosférica e enchentes, deverá aumentar o número de conflitos nos próximos anos." (MAPA DA INJUSTIÇA AMBIENTAL E SAÚDE NO BRASIL, 2010, resultados iniciais).

Os resultados iniciais, nessa mesma linha, apontariam que as populações atingidas seriam majoritariamente povos indígenas (18\%), agricultores familiares (17\%), quilombolas (12\%), pescadores artesanais $(8 \%)$ e ribeirinhos $(7 \%)$. Foram também mapeados os principais danos e impactos ambientais - majoritariamente associados à disputa de terras - e os principais danos e riscos à saúde - majoritariamente vinculado à piora nas condições de vida dessas populações. O relatório de 2010 identificou as atividades responsáveis por provocar conflitos de injustiça ambiental, apontando a liderança da atuação de entidades estatais - em $22 \%$ dos casos - e a monocultura - em $14 \%$ dos casos..$^{90}$

Cumpre frisar

"[...] o dado que mais impressiona no estudo da Fiocruz e da Fase é o que aponta a atuação deficitária do Poder Público como a principal atividade responsável pelas injustiças ambientais brasileiras, tanto pela forma deficitária como os licenciamentos ambientais são realizados, quanto pela ausência de políticas públicas mais efetivas, ou ainda pela própria morosidade e deficiência das instituições da Justiça, na defesa dos interesses coletivos das populações vítimas de injustiças ambientais no Brasil" (Rammê, 2012, p. 52)

A partir das informações fornecidas pelo projeto, é possível observar que em certa medida a metodologia empregada pelos pesquisadores se

\footnotetext{
90 Os resultados atuais não foram ainda disponibilizados, pelo que não é possível tecer comparações e verificar se, sob a mesma metodologia, seria possível verificar alterações ou a concretização da projeção de aumento dos conflitos urbanos.
} 
coaduna a algumas questões levantadas no presente trabalho. Conquanto o estudo tenha sido feito da forma mais abrangente possível, houve notório empenho em discriminar e ressaltar os distintos grupos que sofrem diferentes tipos de violação. Além disso, levou-se em consideração as narrativas dos atingidos e se tomou como objetivo justamente visibilizar essas denúncias. Além disso, o que o Mapa pretende é não só um levantamento dos impactos ecológicos como também englobar problemas referentes a distribuição da terra, alimentação saudável, democracia, cultura e tradições, etc.

Assim,

"[...] o mapeamento dos conflitos ambientais realizado tem por foco a visão das populações atingidas, suas demandas, estratégias de resistência e propostas de encaminhamento. O estudo não desenvolveu trabalhos e avaliações de campo que aprofundassem, do ponto de vista técnico-científico, os detalhes dos impactos ambientais e de saúde. As informações destacadas no casos revelam posições assumidas por parcela expressiva das populações atingidas, seja a partir de suas experiências, seja a partir de relatórios e artigos desenvolvidos por entidades, ONGs e instituições parceiras, inclusive grupos acadêmicos, instituições governamentais, Ministérios Públicos ou órgãos do judiciário. $\mathrm{O}$ fato de tais posições serem muitas vezes contraditórias com as versões apresentadas por outras instituições ou empresas envolvidas expressa, mais que o grau de incertezas e falta de informações existentes, o nível de conflito e de dificuldades no encaminhamento de soluções que atendam aos interesses legítimos das populações atingidas. Ao privilegiarmos a visão de tais populações, buscando não cair em reducionismos ou denúncias inconsequentes, estamos contribuindo, acreditamos, com o papel de dialogar com a sociedade e transformá-la para que sejamos mais democráticos, sustentáveis e saudáveis.” (MAPA DA INJUSTIÇA AMBIENTAL E SAÚDE NO BRASIL, 2010, metodologia)

Também merece menção o Atlas da exclusão social no Brasil: dinâmica e manifestação territorial, resultante um projeto desenvolvido por pesquisadores da Unicamp e da PUC-SP. A pesquisa foi realizada no ano de 2000 e teve por amostra o total de 5.507 municípios e logrou relacionar as áreas de degradação ambiental com os indicadores de exclusão social das regiões. Concluiu-se que, de um total de 33 áreas de risco: a) 24 estavam situadas na área de maior exclusão social; b) 5 estavam localizadas na região representada pela segunda maior exclusão; c) 2 estavam na área de 
terceira maior exclusão; d) somente uma dessas áreas de risco se localizava numa zona de baixa exclusão. (Rammê, 2012). O Índice de Exclusão Social, cumpre elucidar, "[...] é composto a partir de sete outros subíndices, que incorporam as seguintes variáveis: pobreza, emprego, desigualdade, alfabetização, escolaridade, presença juvenil e violência" (Acserald et al, 2009, p. 51).

Como se pode observar, o estudo supracitado não adotou parâmetro racialmente referenciado. Consigne-se, por outro lado, os resultados obtidos pelo IBGE na Pesquisa Nacional de Saneamento Básico que, dentre os indicadores, incluiu a variável "cor". ${ }^{91}$ De acordo com Acserald, Mello e Bezerra, os resultados encontrados apontam que indubitavelmente o aspecto racial constitui uma importante variável de análise da injustiça ambiental no país. Contudo, afirmam não ser ainda possível atestar a existência de racismo ambiental no Brasil;

"De qualquer forma, pode-se atestar a desigualdade racial em
termos de acesso à infraestrutura de saneamento básico pela
referida pesquisa [...]. Repare-se, como um agravante do quadro
de desigualdade racial na oferta de saneamento, que a
metodologia empregada na pesquisa necessariamente joga os
dados sobre o abastecimento dos brancos 'para baixo',
aproximando-os das porcentagens dos não-brancos. Afirmamos
isso baseando-nos no seguinte raciocínio: dado que a 'cor' é
dada pela auto-atribuição do indivíduo, é bem provável que um
número expressivo de pessoas sem saneamento que costuma ser
vítima de discriminação racial tenha afirmado ser de 'cor
branca"” (ibid., p. 52)

Em 2010, o IBGE apresentou resultados de pesquisa sob o seguinte título: Indicadores de Desenvolvimento Sustentável: Brasil 2010, publicado no sítio eletrônico do Instituto. O Programa das Nações Unidas para o Meio Ambiente, por seu turno, publicou documento chamado Geo Brasil 2002: perspectivas do meio ambiente no Brasil. Em ambos, “[...] traçam-se paralelos entre a relação da degradação ambiental e a questão social no

\footnotetext{
${ }^{91} \mathrm{O}$ estudo concluiu que somente $67,2 \%$ da população preta e parda tinha acesso a água canalizada e rede geral de distribuição, no ano de 1999 , contra $82,8 \%$ da população branca, em todo o território nacional. No que diz respeito ao acesso a tratamento de esgoto e fossa séptica, registrouse que enquanto $62,7 \%$ da população branca tinha acesso, somente $39,6 \%$ de negros - pretos e pardos - estavam em condições semelhantes; nas regiões Norte e Nordeste, vale notar, este indicador aponta que apenas $12,7 \%$ e $19,8 \%$ de negros, respectivamente, teriam acesso a esgoto tratado e fossa séptica.
} 
Brasil, amparados em indicadores ambientais, sociais, econômico e institucionais" (Rammê, 2012, p. 53).

Conquanto os estudos empreendidos não sejam racialmente referenciados - isto é, não se dediquem propriamente a aferir a existência ou não de racismo ambiental no Brasil ou em que medida, objetivamente, haveria desigualdades raciais na distribuição dos males ambientais -, há certo consenso de que a variável raça não deve ser desconsiderada. Para Paixão (2004), haveria uma relação entre o processo histórico de incorporação da população afrodescendente no território nacional e os indicadores de violência na zona rural. É que "[...] por um processo histórico de exclusão dos setores dinâmicos da sociedade, grande parcela dessa população acabou concentrando-se no setor agrícola no Brasil" (ibid., p. 54), além do que "em 1999, cerca de $56 \%$ da força produtiva total do setor agrícola brasileiro era formada por homens e mulheres afrodescendentes" (ibid., p. 54).

Em grande medida, o grau de invisibilização do racismo ambiental mesmo em meio a pesquisas relacionadas a justiça ambiental se daria porque

“[...] no Brasil, na medida em que o movimento negro ainda não goza de plena visibilidade quanto às suas demandas e ainda vigora um ideário mistificador das relações raciais, existe muito mais dificuldades para o reconhecimento dos determinantes raciais da maior parte das grandes questões sociais que afligem o país. Se isso ocorre onde todas as evidências são absolutamente incontestáveis (direitos humanos, pobreza e indigência, trabalho infanto-juvenil, acesso à terra, etc.), acaba ocorrendo de forma ainda mais intensa em frentes de luta e intervenção relativamente novas em nosso país, tal como é o caso da justiça ambiental" (Paixão, 2004, p. 166-167).

Finalmente, vale apontar o Mapa de conflitos causados por Racismo Ambiental no Brasil, cujo levantamento inicial data de junho de 2007, realizado por Ribeiro e Pacheco. ${ }^{92}$ Trata-se de extensa listagem de casos de denúncias de racismo ambiental, seja pela própria população afetada, pela mobilização de ativistas, organizações, instituições oficiais, veículos de

\footnotetext{
92 Acessível pelo link: <http://www.cppnac.org.br/wp-content/uploads/2013/11/Mapa-do-
} Racismo-Ambiental-no-Brasil.pdf $>$ Acesso em: 16 de nov. de 2016. 
imprensa, etc., organizados por estado da Federação. É bem de ver que o racismo ambiental não se restringe somente à população negra, como se infere dos resultados do Mapa da Injustiça Ambiental e Saúde no Brasil, mas todo um espectro que compõe a massa não-branca do país. ${ }^{93}$

Assim, a despeito os esforços de pesquisadores como Paixão (2004), Pacheco (2008) e Herculano (2008), é possível verificar que a discussão sobre o racismo ambiental é ainda embrionária no Brasil. As dificuldades apontadas em trabalhos acerca do tema referem-se principalmente às marcas históricas que condenaram não-brancos a piores condições de vida e acesso à terra; às consequências do mito da democracia racial; a hierarquização social experimentada na sociedade brasileira; ao contexto de segregação socioespacial construído no meio urbano; e aos desafios impostos pelo modelo econômico vigente. Há, por fim, a constatação de que a real investigação e combate às injustiças ambientais no país necessariamente demandam reflexões que conjuguem fatores particulares à sociedade brasileira e às camadas de violência nela presentes, não limitadas exclusivamente a uma visão norteada pela luta de classes. A própria configuração do racismo no Brasil aponta para a necessidade pesquisas voltadas ao racismo ambiental, eis que provoca o estabelecimento de condições sociais assimétricas que impactam diretamente questões como a renda, a moradia e o acesso à cidade, por exemplo.

\subsection{Por uma perspectiva racialmente centrada}

As disparidades encontradas na ocupação residencial das grandes cidades se atribuem, ante o exposto, não a um dado natural ou resultado impessoal das relações mercadológicas, mas reproduzem as relações sociais estruturalmente estabelecidas (Harvey, 1980). Com isso, haveria a decorrente imposição desigual de ônus ambientais desproporcionais a grupos racialmente determinados, com a seguinte agravante: tal imposição

\footnotetext{
${ }^{93}$ Tome-se como exemplo o fato de que o Mapa da Injustiça Ambiental e Saúde no Brasil identifica que, das populações que sofrem injustiça ambiental, $18 \%$ é indígena, o que corresponde a $0,25 \%$ da população nacional;
} 
obstacularizaria ainda mais as chances de dela se verem livres e ascender socialmente, na medida em que o acesso distinto à infraestrutura e a recursos básicos da urbe - como saneamento básico, mobilidade urbana e acesso à educação de qualidade - promovem a manutenção da ordem social já estabelecida.

Observe-se que essa alocação espacial da população produz, por si só, um fenômeno de imposição desproporcional de ônus ambientais a grupos racial ou etnicamente discriminados. Como visto, essa característica permanece mesmo quando há certa proximidade física entre os núcleos de agrupamento de classes dominantes e discriminados, potencialmente agravando-se com o distanciamento.

Conforme ressalta Caldeira (2000), mesmo quando as classes altas se movimentam em direção à periferia, não se reduziria o grau de segregação e alienação social, mas o acirramento das relações sociais e espaciais. Nessa esteira, como bem explica Negri (2008),

"o Estado adquire um papel crucial, porque acentua a segregação através de legalizações para a instalação de condomínios fechados, cerceamento de bairros, suburbanização da classe alta, facilitação do transporte, entre outros mecanismos que facilitam a segregação" (Negri, 2008, p. 149).

Há, ademais, os prejuízos da passividade da Administração que, além de permitir a criação de espaços de segregação, não cria espaços comuns de interação ou se dedica ao seu fomento. Daí o esforço do presente trabalho de, à luz dos parâmetros jurídicos de análise já apresentados, expor alternativas e sugestões no trato da questão - sem qualquer pretensão de esgotá-las. Vale ressaltar, o que se propõe é um diálogo construtivo sob e para a perspectiva centrada na busca e fomento da justiça ambiental, com enfoque no combate ao racismo ambiental.

Ante todo o exposto, cumpre questionar a normatividade - na medida em que reflete falhas estruturais presentes na sociedade - e as formas pelas quais o Direito incorpora e estabiliza fenômenos sociais indesejáveis e até incompatíveis com princípios consagrados. Mais do que 
isso, mostra-se pertinente a adoção do fator "raça" como variável de análise, sobretudo no que concerne a questões de justiça ambiental.

Os principais autores referência para o presente trabalho utilizados como termômetro do debate acerca da justiça ambiental no Brasil são Acserald, Mello e Bezerra (2009; 2010), Herculano (2001;2008), Rammê (2012), Rolnik (1989) e Pacheco (2008). O que se pretende é, a partir da conjuntura exposta nos capítulos anteriores, chamar atenção para determinados pontos concernentes a luta por justiça ambiental no Brasil. Não se discute a importância de tratar o meio ambiente como bem comum para o uso de todos e a necessidade de se estabelecer mecanismos para assegurar a sua preservação, mas aponta-se a aprofundar aspectos dessa discussão que transcendem a limitação do olhar ao meio ambiente natural e a não particularização dos graus de exposição a grupos particulares.

Com efeito, a análise da questão tendo o elemento socioeconômico como epicentro é pertinente, porém incompleta. Reconhece-se algumas vantagens - especialmente políticas - da organização do movimento no Brasil nesse sentido: a possibilidade de agregação de diversos segmentos de luta social é um deles. Ao definir a justiça ambiental nesses termos, permite-se que diferentes movimentos - sejam se ordem social, sindical ou racial - renovem e ampliem o alcance da sua luta ao incorporarem "[...] a dimensão da justiça ambiental, o direito a uma vida digna e em um ambiente saudável” (Herculano, 2008, p. 6). Para Herculano (2008), “todas essas lutas representam uma só e mesma luta pela democracia, pelo bem comum e pela sustentabilidade" (ibid., p. 6).

Argumenta a autora:

"Pensamos que o tema da 'justiça ambiental' - que indica a necessidade de trabalhar a questão do ambiente e não apenas em termos de preservação, mas também de distribuição e justiça representa o marco conceitual necessário para aproximar em uma mesma dinâmica as lutas populares pelos direitos sociais e humanos e pela qualidade de vida e a sustentabilidade ambiental. [...]

O termo Justiça Ambiental é um conceito aglutinador e mobilizador, por integrar as dimensões ambiental, social e ética da sustentabilidade e do desenvolvimento, frequentemente 
dissociados nos discursos e nas práticas. Tal conceito contribui para reverter a fragmentação e o isolamento de vários movimentos sociais frente aos processos de globalização e reestruturação produtiva que provocam perda de soberania, desemprego, precarização do trabalho e fragilização do movimento sindical e social como um todo" (ibid., p. 13-15)

A variável classe recebe proeminência - além de em virtude de todas as razões já apontadas no presente trabalho - porque agrupamentos de classe baixa ou menor renda estariam "mais sujeitos aos riscos decorrentes da proximidade de seus locais de moradia dos depósitos de lixo tóxico, das plantas industriais poluentes, das encostas perigosas e dos esgotos a céu aberto" (Acserald et al, 2009, p. 42). Anote-se, por outro lado, a “constatação de que entre os pobres encontra-se em maior proporção a população negra” (Santos, 2015, p. 25).

Ocorre que, dada a amplitude do conceito, as demandas por justiça ambiental abrigam múltiplas e distintas faces, conflitos em diferentes proporções - local, regional, nacional ou global -, podendo se restringir ou não a questões puramente ecológicas. Assim, como bem sintetiza Rammê (2012):

“[...] o conceito de justiça ambiental se apresenta como um conceito 'guarda-chuva', capaz de abarcar todas as formas de ação social vinculadas ao atendimento de que o meio ambiente equilibrado é fator determinante para a subsistência humana" (Rammê, 2012, p. 46).

O ponto nodal do que ora se apresenta permeia a discussão inicialmente apresentada: o perigo de, sob recortes que metodológica e epistemologicamente não distinguem diferentes graus de discriminação, haver certo apagamento ou invisibilização de determinadas formas de violência. Veja-se que o próprio clamor pelo combate ao racismo ambiental nasce por conta dessa prática institucionalizada não só por agências governamentais e entes privados como também por pesquisadores e acadêmicos.

Ocorre que, no Brasil, a questão do racismo ambiental - e de outras possíveis variantes que aumentam o grau de exposição à discriminação institucional - se vê mascarada por desigualdades sociais. Isso provoca a adoção de lentes primordialmente referenciadas pela classe ao invés da 
raça. De um lado, a ampliação da noção de justiça ambiental se mostra interessante e gera grande potencial agregador, por outro, chama atenção à necessidade de agregar múltiplos referenciais teóricos que sejam aptos a lograr estabelecer variáveis de análise que permitam um olhar menos incompleto e mais sensível a essas realidades. A desigualdade social experimentada na sociedade brasileira mascara a desigualdade ambiental:

"[...] dado nosso amplo leque de agudas desigualdades sociais, a exposição desigual aos riscos químicos fica aparentemente obscurecida e dissimulada pela extrema pobreza e pelas péssimas condições gerais de vida a ela associadas. Assim, ironicamente, as gigantescas injustiças sociais brasileiras encobrem e naturalizam a exposição desigual à poluição e o ônus desigual dos custos do desenvolvimento" (Herculano, 2008, p. 5)

Sob a variável classe não ficam em evidência fatores diferenciadores e - possivelmente - desagregadores de diferentes movimentos sociais que se insurjam contra práticas de injustiça ambiental. A realidade da exposição desigual a ônus ambientais no país faz emergir peculiaridades mesmo à luz da variável raça, haja vista a elevada multiplicidade de segmentos étnicoculturais. Há que se atentar ao possível apagamento de uma série de questões particulares sob as designações genéricas "grupos de negros" ou "de indígenas" quando se lida com diferentes formas de violência imposta a populações ribeirinhas, povos tradicionais - de diversas matrizes -, quilombolas, moradores de favelas, população rural, dentre outros.

$\mathrm{O}$ recorte ora estabelecido tem como enfoque o combate ao racismo ambiental, pelo que se defende uma perspectiva racialmente centrada - não se ignora, contudo, a necessidade de sobrepor outras lentes ante o reconhecimento de hierarquias sociais de outra natureza. ${ }^{94}$ Essa perspectiva, defende-se, deve nortear a própria prática jurídica - desde o processo legislativo à aplicação e interpretação das normas. Silva (2015) é incisiva:

\footnotetext{
94 Veja-se que, de acordo com Herculano (2008), "a irresponsabilidade ambiental das empresas atinge em primeiro lugar e com maior intensidade as mulheres, a quem cabe frequentemente a lavagem dos uniformes de trabalho contaminados de seus maridos ou o manejo de recipientes de agrotóxico transformados em utensílios de cozinha." (Herculano, 2008, p. 12)
} 
"Apesar da suposta universalidade das normas jurídicas, a seletiva indicação dos padrões morais e de normalização que identificam o tipo de proteção e os sujeitos protegidos impõe que uma avaliação crítica do direito - aquela comprometida com a identificação da realidade e suas estruturas de poder e obstáculos existentes à emancipação dos sujeitos subalternizados - descortine as estruturas de distribuição de poder, bem como os critérios que sustentam o modelo de dominação confrontado. A cegueira de cor, assim como a defesa de uma perspectiva neutra, objetiva, imparcial e ahistórica da realidade levam, ao contrário, à preservação das hierarquias raciais, de gênero, morais e sociais que se pretende superar." (Silva, 2015, p. 65).

Dentre os resultados negativos de uma perspectiva racialmente "neutra" está a produção de distorções pela sua aplicação a um contexto desigual, que não reflete a igualdade jurídico-formal. A padronização formulada nos moldes da cultura dominante provoca - dentre outras perversidades - a formação de uma autoimagem distorcida de grupos racialmente discriminados que, legitimada pelo método científico, alça a categoria de "verdade" e é absorvida ou naturalizada pela sociedade em geral e - importante ressaltar - pelos membros daquele grupo. ${ }^{95}$

Daí que se propõe a construção de uma perspectiva epistemológica que, centrada nas particularidades brasileiras, identifica e utiliza os parâmetros indicados pela Teoria Crítica da Raça. Cumpre anunciar, pelo intercâmbio de pesquisadores brasileiros com o trabalho de Bullard e outros pesquisadores estadunidenses, algumas iniciativas nacionais já fazem uso de uma das premissas da TCR que é a de privilegiar a narrativa dos sujeitos afetados, permitindo que os próprios grupos minoritários falem por si.

A partir da tese centro-periferia de Prebisch - de que dentro do sistema de relações econômicas internacional países industrializados ocupariam uma posição de centro, ao passo que países em desenvolvimento, tais como os latino-americanos, ocupariam uma posição periférica -, assinala-se que haveria a externalização do custo produtivo de economias centrais para economias periféricas (Rammê, 2012). Desse modo, haveria uma transferência de custos que perpetuaria a condição

\footnotetext{
${ }^{95}$ Essa distorção afeta especialmente crianças que, imersas num intenso processo de formação da sua própria auto-imagem e subjetividade somada ao pouco tempo de experiência de vida, têm menores condições de resistir.
} 
periférica e dependente dos países em desenvolvimento, gerando um gap de difícil superação em relação aos países centrais.

Young e Lustosa (2003) inserem a problemática ambiental na discussão apresentada por Prebisch, modo pelo qual organizam nesse contexto casos e demandas de justiça ambiental. $\mathrm{O}$ esquema elaborado evidenciaria a existência de uma "dupla exclusão": uma delas em virtude de uma desigual distribuição dos ônus ambientais resultantes dos "frutos do progresso" entre diferentes povos e nações; a outra, relacionada aos males ambientais, vez que seriam as parcelas da população global mais excluídas que arcariam com as mazelas oriundas da poluição gerada.

Assim,

“[...] com o despertar ecológico; a partir da década de 70, a matriz industrial dos países do centro, substancialmente baseada na queima de combustíveis fósseis, e, consequentemente, de alto grau poluente, passou a ser seriamente questionada por movimentos sociais desses países, que reivindicavam que as atividades produtivas fossem mais severamente controladas pelos governos ou mesmo banidas de seus territórios.Com as crescentes restrições ambientais para atividades poluidoras nos países do centro, ocorreu o fenômeno da expansão das indústrias poluentes para os países da periferia, fazendo com os países periféricos, além da dependência crônica dos países do centro, decorrente da desigual distribuição dos ganhos de produtividade, também passassem a conviver com elevados níveis de poluição industrial" (Rammê, 2012, p. 62)

A questão denota não só a necessidade de revisão dos parâmetros metodológicos e epistemológicos para a análise da questão no plano doméstico, como uma reavaliação da lente utilizada para a leitura da dinâmica internacional concernente à matéria. O diálogo proposto é a adoção de uma perspectiva afrocêntrica associada à noção de amefricanidade, ao invés de paradigmas eurocentrados. ${ }^{96}$

De acordo com Asante (2009),

"A ideia de afrocentricidade refere-se essencialmente à proposta epistemológica do lugar. Tendo sido os africanos [aqui entendidos como afrodescendentes no continente africano e na diáspora em todo o mundo] deslocados em termos culturais,

\footnotetext{
96 Vale dizer, o que se levanta não é novidade no cenário brasileiro, os ideais incorporados nessa perspectiva já compunham o leque de pautas de ícones como Abdias Nascimento e Guerreiro Ramos que já teriam levantado questões acerca do multiculturalismo e da noção de supremacia branca, o que se refletiria na atuação do Teatro Experimental Negro - TEN.
} 
psicológicos, econômicos e históricos, é importante que qualquer avaliação de suas condições em qualquer país seja feita com base em uma localização centrada na África e sua diáspora. Começamos com a visão de que a afrocentricidade é um tipo de pensamento, prática e perspectiva que percebe que os africanos como sujeitos e agentes de fenômenos atuando sobre sua própria imagem clura e de acordo com seus próprios interesses humanos" (Asante, 2009, p. 93)

Uma perspectiva afrocêntrica se apresenta como alternativa à adoção de paradigmas epistemológicos eurocêntricos, na medida em que “[...] reorienta as investigações sobre as relações raciais dando aos negros uma posição central na análise" (Silva, 2015, p. 69), e “[...] não essencializa identidades, tampouco romantiza os elementos constitutivos dos valores africanos" (ibid., p. 69).

Silva (2015) sintetiza algumas das características - elencadas por Asante - que devem estar presentes na configuração de um projeto afrocêntrico, são elas:

“1) interesse pela localização psicológica - pelo lugar psicológico, cultural, histórico ou individual ocupado por uma pessoa em dado momento e em determinado espaço - central ou marginal com respeito à sua cultura; 2) compromisso com a descoberta do lugar do africano como sujeito - normalmente as discussões sobre assimetrias raciais tem se dado com base naquilo que pensam, fazem e dizem os europeus, e não no que os próprios negros pensam, dizem e fazem; 3) defesa dos elementos culturais africanos - a orientação teórica voltada para a agência africana deve assumir e respeitar a dimensão criativa de suas personalidades; 4) compromisso com o refinamento léxico - com o objetivo de desvelar e corrigir as distorções decorrentes do léxico convencional (eurocentrado) sobre a história africana; 5) compromisso com uma nova narrativa da história da África - retirando a África do lugar de inferioridade nos campos de pesquisa, na deliberada falsificação do registro histórico empreendido pelas epistemologias dominantes" (ibid., p. 70).

A noção de amefricanidade de Gonzalez (1988) também se mostra pertinente, sobretudo com vistas a complementar as questões comunicadas pela Teoria Crítica da Raça e pela perspectiva afrocêntrica. De acordo com a autora,

"As implicações políticas e culturais da categoria amefricanidade ("Amefricanity") são, de fato, democráticas; exatamente porque o próprio termo nos permite ultrapassar as limitações de caráter territorial, linguístico e ideológico, abrindo novas perspectivas para um entendimento mais profundo dessa parte do mundo onde ela se manifesta: A AMÉRICA e como 
um todo (Sul, Central, Norte e Insular). Para além do seu caráter puramente geográfico, a categoria de Amefricanidade incorpora todo um processo histórico de intensa dinâmica cultural (adaptação, resistência, reinterpretação e criação de novas formas) que é afrocentrada, isto é, referenciada em modelos como: a Jamaica e o akan, se modelo dominante; o Brasil e seus modelos yourubá, banto e ewe-fon.

[...] Seu valor metodológico, a meu ver, está no fato de permitir a possibilidade de resgatar uma unidade específica, historicamente forjada no interior de diferentes sociedades que se formaram numa determinada parte do mundo. Portanto, a Améfrica, enquanto sistema etnográfico de referência, é uma criação nossa e de nossos antepassados no continente em que vivemos, inspirados em modelos africanos. [...] Embora pertençamos a diferentes sociedades do continente, sabemos que o sistema de dominação é o mesmo em todas elas, ou seja: o racismo, essa elaboração fria e extrema do modelo ariano de explicação, cuja presença é uma constante em todos os níveis de pensamento, assim como parte e parcela das mais diferentes instituições dessas sociedades." (Gonzalez, 1988, p. 76-77)

Retomando as críticas iniciais a respeito do racismo civilizacional, chama-se à construção de metodologias e epistemologias que, voltadas à análise do racismo ambiental no Brasil, fundamentem-se na experiência africana e latino-caribenha. Somado a isso, defende-se a adoção de variáveis de análise que não só vislumbrem a questão de classe, mas que também ponham em evidência aspectos relacionados a perspectivas de raça, gênero, religiosidade, etc. Como bem assinala Silva (2015), a categoria político-cultural de Gonzalez denota “[...] um inegável compromisso com o rompimento com qualquer resquício do colonialismo imperialista, notadamente em termos epistêmicos" (Silva, 2015, p. 71).

Reconhece-se a importância dos esforços ora empreendidos pelo movimento por justiça ambiental no Brasil. Há, de fato, urgência na luta por mudanças pontuais e mais imediatas, tais como: o pleito por garantia de livre e seguro acesso à informação pela população afetada a respeito de empreendimento aptos a provocar injustiças ambientais; a adoção de regras que implementem medidas de difusão da informação e garantia da segurança na participação popular; democratização e maior transparência no processo decisório, bem como efetiva investigação, apuração e punição equitativa pelo descumprimento da legislação; dentre outras. Ocorre, porém, que não só essas medidas não são avaliadas sob um recorte que 
ponha em destaque potenciais múltiplos graus de violência e injustiça ambiental, empobrecendo a discussão de como minimizá-los, como não atacam as bases do problema, que residem em níveis mais profundos - ou, na gramática de Scheurich e Young (1997), em nível civilizacional.

Existem uma série de esforços desejáveis para calibrar distorções geradas pela adoção de parâmetros eurocentrados, tais como (em rol exemplificativo): a) a mobilização de ações e estratégias que objetivem combater a injustiça ambiental, o racismo ambiental e as bases da discriminação institucional a partir do empoderamento dos grupos marginalizados; b) a configuração do papel central do conhecimento e experiência dos grupos afetados, não só como fonte de pesquisa mas como matéria-prima reconhecida pelo seu potencial emancipatório (Silva, 2015); c) o confronto das metodologias, epistemologias e formas de conhecimento, apreensão e análise da questão racial, fomentando a ampliação do leque utilizável no método científico, sobretudo a partir de uma perspectiva transdisciplinar. ${ }^{97}$

É digno de nota que

"Há uma aceitação ampla ao argumento de que o direito no
Brasil não serviu como mecanismo de segregação entre brancos
e não brancos e de que as desigualdades por aqui são resultado
da luta de classes. No entanto, são significativas as normas
jurídicas brasileiras de caráter essencialmente seletivo, cujo
critério racial foi nitidamente utilizado para definir
normativamente os grupos sociais a serem excluídos (PIRES,
2013). Sob o manto da neutralidade e da color-blindness a
suposta indiferença face à identidade racial dos indivíduos
produziu a naturalização da subcidadania e a pernóstica
utilização de características étnicoraciais como mecanismo de
exclusão. Romper com essa realidade pressupõe compartilhar
uma color-consciouness orientada à promoção da igualdade,

${ }^{97}$ É de se notar que "a proposta de fomentar técnicas investigativas sobre esse prisma orienta-se pela tentativa de promover o diagnóstico presente da ideologia que sustenta o racismo, nomeando as lesões racistas e empoderando suas vítimas, que passam a falar por elas mesmas. Serão as suas experiências as fontes privilegiadas de uma forma de produzir conhecimento que até então impediu que elas ecoassem - por exigências de suposta neutralidade, objetividade e universalidade. Se as estatísticas não mostram a real situação social dos negros, porque a exigência de uma postura estatal color blind impedia que produção de dados fosse orientada por cortes de cor ou raça, gênero, orientação sexual, filiação religiosa, etc., e se as investigações até então dotadas de cientificidade estavam pautadas no ideal cartesiano ou não atribuíam ao critério raça um locus privilegiado de análise, só a experiência pode demonstrar e denunciar as marcas cotidianas do enfrentamento ao racismo e suas principais implicações." (Silva, 2015, p. 73). 
cidadania e respeito dos estratos tradicionalmente não reconhecidos. Nesse sentido, esse trabalho não compartilha da máxima de que não houve segregação legal no Brasil contra não brancos, apenas os mecanismos normativos de segregação operaram segundo uma lógica distinta daquela evidenciada pelos regimes de apartheid vivenciados nos Estados Unidos e na África do Sul.” (Silva, 2015, p. 79)

Do enfrentamento da questão racial no Brasil emergem contraposições calcadas em noções já naturalizadas na sociedade. A ordem de ações apontadas anteriormente, conquanto pertinentes como conjunto de ações imediatas e emergenciais, não são aptas a lidar diretamente com argumentos que trazem à baila mitos acerca da meritocracia, da democracia racial ou argumentos pela adoção de uma perspectiva insensível a cor. Finalmente, vale dizer que é justamente a crença na possibilidade de se alçar a norma jurídica a uma suposta universalidade e neutralidade absolutas que imobiliza e cerceia discussões acerca do papel do direito no contexto de violações e desigualdades raciais. 


\section{Conclusão}

Diante do contexto apresentado, é possível compreender o ponto nodal da análise que ora se empreende: o anseio de inaugurar um diálogo construtivo à luta por justiça ambiental, de modo que se permita a pluralidade e ampliação de lentes e mecanismos de análise utilizados. A compreensão dos males de origens do problema, defende-se, demanda a riqueza que uma produção coletiva que se fortalece na multiplicidade pode oferecer. Há que se repensar o processo de estruturação de nossas instituições e refletir acerca do processo pelo qual se constituiu o nosso povo, especialmente a partir de referenciais não exclusivamente eurocentradas ou de lentes gestadas a partir da experiência europeia.

$\mathrm{O}$ recorte que aqui se estabeleceu dá enfoque à adição à análise da injustiça ambiental a parâmetros racialmente referenciados como epicentro de análise. Não se exclui, porém, o estímulo a olhares que logrem posicionar outros vetores e parâmetros que lancem luz sobre aspectos frequentemente obscurecidos nesse cenário. Como dito, a repetida análise da questão tendo o elemento socioeconômico como vetor primordial é útil e benéfica, ainda que incompleta.

Insta salientar que não apenas se postula a adoção do fator "raça" como uma das variáveis centrais de análise, como uma revisão e reflexão a respeito das metodologias e epistemologias empregas no estudo do direito e das questões relativas à justiça ambiental no Brasil. A reflexão que se buscou instigar diz respeito aos perigos de, sob recortes metodológica e epistemologicamente não distinguem diferentes graus de discriminação, haver certo apagamento ou invisibilização de determinadas formas de violência. $\mathrm{O}$ fato da questão racial no Brasil ser frequentemente mascarada pela forte desigualdade social do país provoca - frequentemente - a adoção de lentes que são primordialmente referenciadas pelo caractere socioeconômico, afastando dos holofotes as raízes da discrepância socioeconômica observada. 
Em virtude disso, propõe-se a construção de uma perspectiva epistemológica centrada nas particularidades brasileiras, na experiência e trajetória de nosso povo, ao revés da adoção de lentes eurocentradas. Apresenta-se, portanto, a ideia de afrocentricidade, que desloca a perspectiva epistemológica, centralizando-a na experiência e trajetória do povo negro. Tempera-se a proposta com a noção de amefricanidade, de sorte que aquela visão se combina à experiência brasileira a partir das relações estabelecidas do contexto latino-americano e caribenho.

Assim, o primeiro passo é justamente dar um passo atrás: não só se encare as questões que surgem na ponta final das relações de injustiça ambiental, ou seja, que são por elas produzidas, mas se reflita a respeito das possíveis premissas que consagram e permitem a constante manutenção da injustiça social. Reconhecida a existência do racismo institucional, há também espaço para a reflexão a respeito de outras possíveis categorias de discriminação que tenham alçado tal nível, ampliando o leque transdisciplinar que ora se promove. 


\section{Bibliografia}

ACSERALD, Henri et al. O que é justiça ambiental. Rio de Janeiro: Garamond, 2009. 156p.

ACSERALD, H. Ambientalização das lutas sociais: o caso do movimento por justiça ambiental. Estudos Avançados, vol. 24, n. 68, 2010. Disponível em: <http://www.scielo.br/scielo.php?script=sci_arttext\&pid=S010340142010000100010\&lng=pt\&nrm=iso\&tlng=pt $>$ Acesso em: 22 jul. 2015.

ALENCASTRO, Luis Felipe. O trato dos viventes: formação do Brasil no Atlântico Sul. São Paulo, Companhia das Letras, 2000. 355p.

ANJOS, Gabriele. A questão "cor" ou "raça" nos censos nacionais. Indic. Econ. FEE, v. 41, n 1 , abr. 2013, p. 103-118.

ASANTE, Molefi Kete Afrocentricidade: notas sobre uma posição disciplinar. In: NASCIMENTO, Elisa Larkin. Afrocentricidade: uma abordagem epistemológica inovadora. $1^{\mathrm{a}}$ ed. São Paulo: Selo Negro, 2009. p. 93-110.

AZEVEDO, Celia Maria Marinho de. Onda Negra, Medo Branco: o Negro no Imaginário das Elites Século XIX. $3^{\mathrm{a}}$ ed. São Paulo: Annablume, 2004. 254p.

BOMFIM, Manoel. A América Latina: Males de Origem. Rio de Janeiro: Topbooks Editora, 2005. 390p.

BRULLE, Robert; PELLOW, David Naguib. The future of the environmental justice movements. In: BRULLE, R. PELLOW, D. N. Power, justice and environmental: a critical appraisal of the environmental justice movement. Cambridge: MIT Press, 2005.

BULLARD, Robert. Dumping in Dixie: race, class and environmental equality. $3^{\mathrm{a}}$ ed. Colorado: Westview Press, 2000. 234p.

BULLARD, Robert. Confronting Environmental Racism in the Twenty-First Century. Global Dialogue, v. 4, n. 11, winter. 2002. 
Disponível em: <http://www.worlddialogue.org/content.php?id=179> Acesso em: 26 jun. 2015.

BULLARD, Robert. Unequal Protection: Environmental Justice and Communities of Color. San Francisco: Sierra Book Club, 1994. 392p.

CALDEIRA, Teresa Pires. Cidade de Muros: crime, segregação e cidadania em São Paulo. São Paulo: 34/Edusp, 2000. 400p.

COLE, Luke; FOSTER, Sheila. From the ground up: environmental racism and the rise of environmental justice movement. New York e London: New York University Press, 2001.

CRENSHAW, Kimberle. Twenty Years of Critical Race Theory: Looking Back to Move Forward. Connecticut Law Review, v. 43, 2011, p. 1253-1352.

FREYRE, Gilberto. Casa-Grande e Senzala. 52a ed. São Paulo: Global Editora, 2013. 727p.

HARVEY, David. A Justiça Social e a Cidade. São Paulo: Hucitec, 1980. 291p.

HARVEY, David. Cidades Rebeldes: do direito à cidade à revolução urbana. São Paulo: Martins Fontes, 2014. 294p.

HERCULANO, Selene. O clamor por justiça ambiental e contra o racismo ambiental. Revista de Gestão Integrada em Saúde do Trabalho e Meio Ambiente, v. 3, n. 1, Artigo 2, jan./abr. 2008.

HERCULANO, Selene. Justiça ambiental: de Love Canal à Cidade dos Meninos, em uma perspectiva comparada. In: MELLO, M. P. (Org.). Justiça e sociedade: temas e perspectivas. São Paulo: LTr, 2001.

HOFBAUER, Andreas. O conceito de "raça" e o ideário do "branqueamento" no século XIX - bases ideológicas do racismo brasileiro. Teoria \& Pesquisa, n. 42 e 43, jan/jul 2003. p. 63-110.

HOFBAUER, Andreas. Uma história de branqueamento ou o negro em questão. São Paulo: UNES, 2006. 453p. 
HOFFMAN, Florian. Interseccionalidade sistêmica? Breves comentários sobre a luta contra a discriminação racial no âmbito internacional. In: PAIVA, Angela R. (Org.) Notícias e reflexões sobre a discriminação racial. Rio de Janeiro: PUC-Rio: Pallas, 2008. p. 103-109.

HOLANDA, Sergio Buarque. Raízes do Brasil. 26 ${ }^{\text {a }}$ Ed. São Paulo: Companhia das Letras, 1995. 220p.

JACCOUD, Luciana; BEGHIN, Nathalie. Desigualdades raciais no Brasil: um balanço da intervenção governamental. Brasília: Ipea, 2002. $152 \mathrm{p}$.

JACCOUD, Luciana. Racismo e República: o debate sobre o branqueamento e a discriminação racial no Brasil. In: THEODORO, Mario. (Org.), As políticas públicas e a desigualdade racial no Brasil: 120 anos. Brasília: Ipea, 2008. p. 45-64.

KUJAWA, Israel; KUJAWA, Henrique. Estatuto das Cidades: Interfaces entre Gestão Democrática e as Políticas Públicas. In: MUSSI, Andrea Quadrado et al (Org.) Estatuto da cidade: os desafios da cidade justa. Passo Fundo: IMED, 2011. p. 238-251.

LAWRENCE III, Charles. The Id, the Ego, and Equal Protection: Reckoning with Unconscious Racism. Stanford Law Review, v. 39, n. 2, jan./1987, p. 317-388.

LAWRENCE III, Charles. Unconscious Racism Revisited: Reflections on the Impact and Origins of "The Id, the Ego, and Equal Protection”. Georgetown Law Faculty Publications, Georgetown, v. 40, n. 4, abril/2010, p. 931-977.

LEAL, Rogerio Gesta. Marcos normativos fundantes da cidade democrática de direito no Brasil. In: MUSSI, Andrea Quadrado et al. (Org.) Estatuto da cidade: os desafios da cidade justa. Passo Fundo: IMED, 2011. p. 22-33.

MAGALHÃES, Alex Ferreira. $O$ Direito das Favelas. Rio de Janeiro: Letra Capital, 2013. 462p. 
MAIO, Marcos Chor. O Projeto UNESCO e a Agenda das Ciências Sociais no Brasil dos Anos 40 e 50. Revista Brasileira de Ciências Sociais, vol. $14, n^{\circ} 41$, out. 1999 , p. 141-158.

MARCUSE, Peter. Enclaves, sim; guetos, não: a segregação e o Estado. Espaço e Debates. São Paulo: NERU. v. 24, n. 45, jan./jul. 2004, p. 24-33.

MATSUDA, Mari. Voices of America: Accent, antidiscrimination law, and a jurisprudence for the last reconstruction. Yale Law Journal, 100, 1991, p. 1329-1407.

MELLO, Celso Antonio Bandeira de. Eficácia das Normas Constitucionais sobre Justiça Social. In: PIOVESAN, Flavia; GARCIA, Maria. (Org.) Direitos Econômicos, Sociais, Culturais e Ambientais. São Paulo: Revista dos Tribunais, 2011. p. 209-238. (Coleção Doutrinas Essenciais, v. 3)

MÉTRAUX, Alfred; COELHO, Ruy. Suggestions of research on race relations in Brazil. In: Race questions \& protection of minorities. Unesco archives, 10p.

MILARÉ. Edis. Direito do Ambiente. $8^{a}$ ed. rev., atual. e ampl. São Paulo: Revista dos Tribunais, 2013. 1614p.

NEGRI, Silvio Moisés. Segregação Sócio-Espacial: Alguns Conceitos e Análises. Coletâneas do Nosso Tempo, Ano VII - v. 8, n. 08, 2008, p. 129-153.

NINA RODRIGUES, Raimundo. As raças humanas $e$ a responsabilidade penal no Brazil. Rio de Janeiro: Guanabara, 1957.

PACHECO, Tania. Inequality, environmental injustice, and racism in Brazil: beyond the question of colour. Development in Practice, v. 18, n. 6, nov. 2008. Tradução disponível em: < http://racismoambiental.net.br/textos-e-artigos/desigualdade-injusticaambiental-e-racismo-uma-luta-que-transcende-a-cor/> Acesso em 16 nov. 2016. 
PAIXÃO, Marcelo. O verde e o negro: a justiça ambiental e a questão racial no Brasil. In: ACSERALD, Henri et al (Org). Justiça Ambiental e Cidadania. Rio de Janeiro: Relume Dumará, 2004.

PRADO JÚNIOR, Caio. Formação do Brasil Contemporâneo: Colônia. 23ª ed. São Paulo: Brasiliense, 2007. 390p.

PEREZ, Maurício Dominguez. Lacerda na Guanabara: a reconstrução do Rio de Janeiro nos anos 1960. Rio de Janeiro: Odisséia Editorial, 2007.

QUIJANO, Aníbal. Colonialidade do poder, eurocentrismo e América Latina. In: A colonialidade do saber: eurocentrismo e ciências sociais. Perspectivas latino-americanas. Edgardo Lander (org.). Colección Sur Sur, CLACSO, Ciudad Autónoma de Buenos Aires. Argentina: 2005, p. 227-278.

RAMMÊ, Rogério Santos. Da justiça ambiental aos direitos $e$ deveres ecológicos: conjecturas político-filosóficas para uma nova ordem jurídico-ecológica. Rio Grande do Sul: Educs, 2012. 203p.

RIBEIRO, Darcy. O povo brasileiro: A formação e o sentido do Brasil. 2a Ed. São Paulo: Companhia das Letras, 2005. 476p.

ROCHA, Júlio Cesar de Sá da. Função Ambiental da Cidade: direito ao meio ambiente urbano ecologicamente equilibrado. São Paulo: Juarez de Oliveira, 1999. 57p.

ROCHA, Oswaldo Porto. A Era das Demolições. $2^{\mathrm{a}}$ ed. Rio de Janeiro: Secretaria Municipal de Cultura, Dep. Geral de Doc.e Inf. Cultural, Divisão de Editoração, 1995. 181p.

RODRIGUES, José Honório. A Assembleia Constituinte de 1823. Petrópolis: Vozes Ltda, 1974. 325p.

ROLNIK, Rachel. Territórios negros nas cidades brasileiras. Revista de Estudos Afro-Asiáticos, n. 17, set. 1989, p. 35-51. Disponível em: $<$ https://raquelrolnik.files.wordpress.com/2013/04/territc3b3riosnegros.pdf> Acesso em: 22 jul. 2015. 
SANTOS, Alexandre Pereira et al. A Nova Política Habitacional Brasileira e a Prática do Planejamento Urbano: o Plano Local de Habitação de Interesse Social (PLHIS) como Matéria de Interesse Urbanístico. In: MUSSI, Andrea Quadrado et al (Org.) O. Estatuto da cidade: os desafios da cidade justa. Passo Fundo: IMED, 2011. p. 178-195.

SANTOS, Angela Moulin Simões Penalva et al. Política Urbana no Rio de Janeiro: entre a cidade do plano e a cidade real. In Cadernos do Desenvolvimento Fluminense, Rio de Janeiro, n. 2, jul. 2013. Disponível em: <http://www.e-publicacoes.uerj.br/index.php/cdf/article/ view/9085>. Acesso em 12 set. 2016.

SANTOS, Ivair Augusto Alves dos. Direitos humanos e as práticas de racismo. Brasília: Edições Câmara, 2015. 298 p.

SARLET, Ingo Wolfgang. A Eficácia dos Direitos Fundamentais. 5a ed. rev., atual. e ampl. Porto Alegre: Livraria do Advogado, 2005. 464p.

SARLET, Ingo Wolfgang. O Direito Fundamental à Moradia na Constituição: algumas anotações a respeito do seu conteúdo e possível eficácia. In: PIOVESAN, Flavia; GARCIA, Maria. (Org.) Direitos Econômicos, Sociais, Culturais e Ambientais. São Paulo: Revista dos Tribunais, 2011. p. 677-735. (Coleção Doutrinas Essenciais, v. 3)

SARLET, Ingo Wolfgang. Dignidade da Pessoa Humana e Direitos Fundamentais na Constituição Federal de 1988. 9a ed., rev. e atual. Porto Alegre: Livraria do Advogado, 2012. 175p.

SCHEURICH, James Joseph.; YOUNG, Michelle D. Coloring Epistemologies: Are Our Research Epistemologies Racially Biased? Educational Researcher, vol. 26, n. 4, mai. 1997. p. 4-16.

SCHOLBERG, David. Defining environmental justice: theories, movements and nature. New York: Oxford University Press, 2009.

SCHWARCZ, Lilia Moritz. Usos e abusos da mestiçagem e da raça no Brasil: uma história das teorias raciais em finais do século XIX. AfroÁsia, n. 18, 1996. p. 77-101. 
SILVA, Caroline Lyrio; PIRES, Thula Rafaela de Oliveira. Teoria Crítica da Raça como referencial teórico necessário para pensar a relação entre direito e racismo no Brasil. In: STEINMETZ, Wilson Antônio et al (Org.) Direitos dos Conhecimentos. Santa Catarina: XXIV Encontro Nacional do CONPEDI, 2015. p. 61-85.

SOLÓRZANO, Daniel. G.; YOSSO, Tara J. Critical Race Methodology: Counter-Storytelling as an Analytical Framework for Education Research. Qualitative Inquiry, fev. 2002. Disponível em: < http://qix.sagepub.com/content/8/1/23>. Acesso em: 12 out. 2016.

SOLÓRZANO, Daniel et al. Critical Race Theory in Chicana/O Education. National Association for Chicana and Chicano Studies Annual Conference, Paper 9, p. 89-104, 2001. Disponível em <http://scholarworks.sjsu.edu/naccs/2001/Proceedings/9>. Acesso em 3 de novembro de 2016.

THEODORO, Mario. A formação do mercado de trabalho e a questão racial no Brasil. In: THEODORO, Mario. (org), As políticas públicas e a desigualdade racial no Brasil: 120 anos. Brasília: Ipea, 2008. p. 15-44.

VARGAS, João H. Costa. Apartheid brasileiro: raça e segregação residencial no Rio de Janeiro. Revista de Antropologia. vol. 48, n. 1. 2005. p. 75-131.

VASCONCELOS, Pedro de Almeida. A aplicação do conceito de segregação residencial ao contexto brasileiro na longa duração. Revista Cidades. v.1, n. 2, 2004, p. 259-274.

VAZ, Anderson Rosa. A Cláusula da Reserva do Financiamente Possível como Instrumento de Efetivação Planejada dos Direitos Humanos, Econômicos, Sociais e Culturais. In: PIOVESAN, Flavia; GARCIA, Maria. (Org.) Direitos Econômicos, Sociais, Culturais e Ambientais. São Paulo: Revista dos Tribunais, 2011. p. 107-136. (Coleção Doutrinas Essenciais, v. 3) 
VILLAÇA, Flavio. A Segregação Urbana e a Justiça (ou A Justiça no Injusto Espaço Urbano). In: MUSSI, Andrea Quadrado et al (Org.) Estatuto da cidade: os desafios da cidade justa. Passo Fundo: IMED, 2011. p. 47-55.

VILLAÇA, Flavio. A segregação e a estruturação do espaço intraurbano: o caso do Recife (2001). Disponível em: <www.flaviovillaca.arq.br>. Acesso em: 18 out. 2016.

YOUNG, Carlos Eduardo Frickmann; LUSTOSA, Maria Cecília Junqueira. A questão ambiental no esquema centro-periferia. Economia, v. 4, n. 2, Niterói/RJ, jul./dez. 2003, p. 201-221. 